\title{
Perinatal risk factors for type 1 diabetes in children and adolescents
}

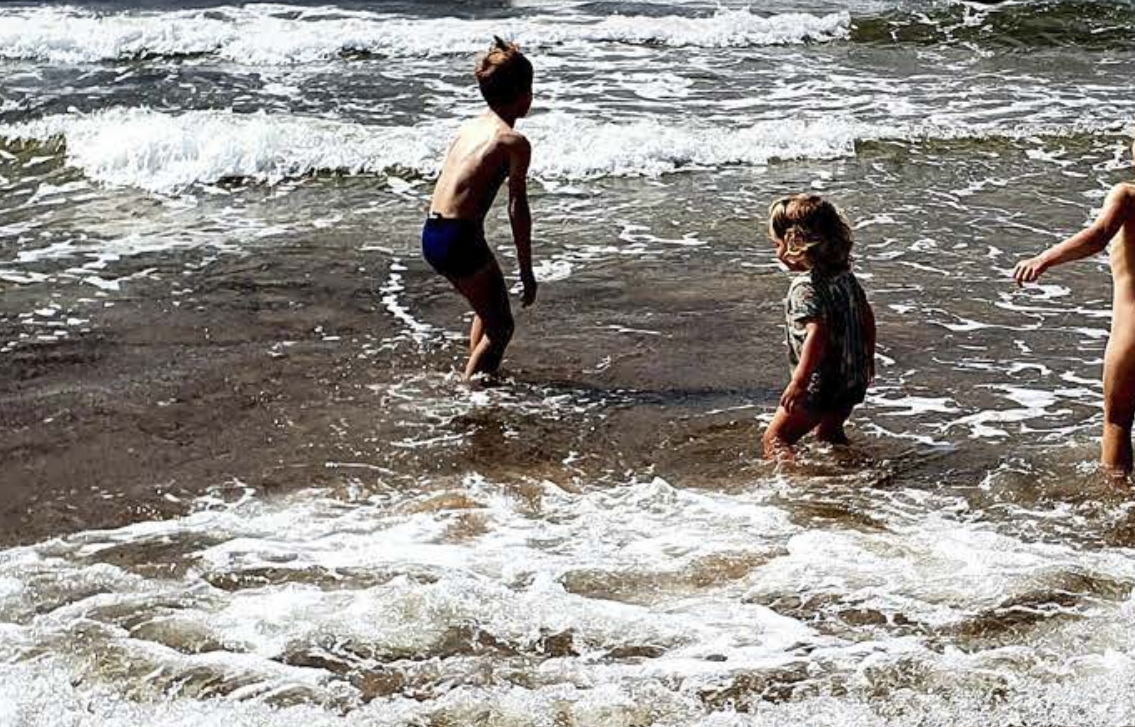

\section{Nina Lindell}

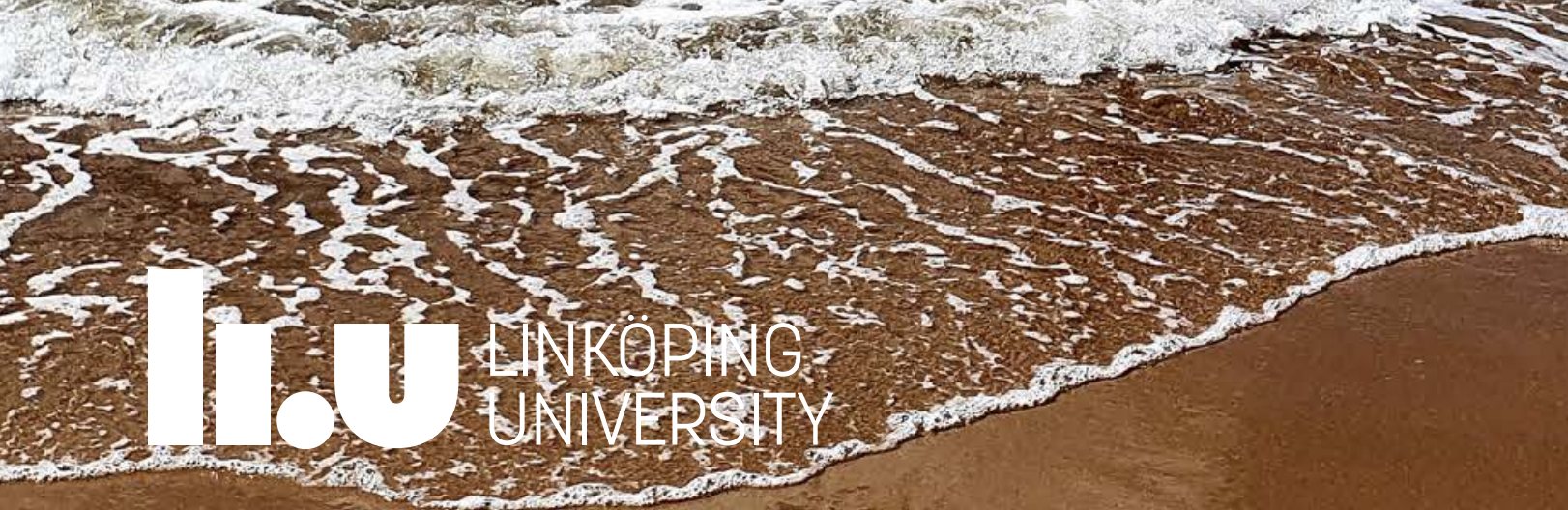



Linköping University Medical Dissertation

No. 1789

\section{Perinatal risk factors for type 1 diabetes in children and adolescents}

Nina Lindell

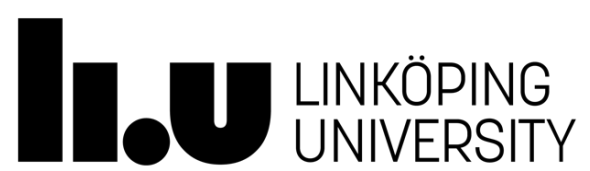

Department of Obstetrics and Gynecology

Department of Biomedical and Clinical Sciences

Linköping University, Linköping, Sweden

Linköping 2021 


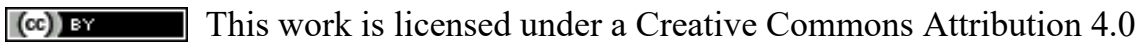
International License.

https://creativecommons.org/licenses/by/4.0

Perinatal risk factors for type 1 diabetes in children and adolescents

(C) Nina Lindell 2021

ISBN: 978-91-7929-019-1

ISSN: 0345-0082

Printed by LiU-Tryck, Linköping, Sweden, 2021 
To my family

"What a precious privilege it is to be alive - to breathe, to think, to enjoy, to live." -Marcus Aurelius 



\section{ABSTRACT}

\section{Background}

Type 1 diabetes (T1D) is an autoimmune disease characterized by progressive loss of the insulin producing pancreatic $\beta$-cells. The disease process starts years before the clinical diagnosis. The cause of T1D is unknown, but it is believed to be a combination of genetic and environmental factors. Around $50 \%$ of the genetic risk is attributed to the human leucocyte antigen (HLA) genes and the strongest associations are with the HLA-DR3-DQ2 and HLADR4-DQ8 haplotypes. The highest risk genotype is the heterozygote form of the two, the HLA-DQ2/8 genotype. It may be that certain environmental factors pose a risk to individuals with a particular genetic susceptibility but not to others.

In the last few decades T1D incidence has risen very quickly and due to the rate of the increase, it is believed to depend on environmental factors rather than genetic. In parallel with this increase, the incidence of several environmental factors has also risen i.e., the incidence of cesarean section (CS), overweight/obesity in the general population and birthweight. These environmental factors have been implicated as risk factors for T1D, but studies have had conflicting results.

\section{Objective}

The overall aim of this thesis was to increase knowledge regarding factors during pregnancy and the perinatal period that could increase or decrease the risk of T1D among children and adolescents. The environmental risk factors studied were mode of childbirth (study I), maternal BMI and gestational weight gain (GWG) (study II) and the child's size for gestational age and birthweight (study III). In the last study the environmental risk factors were compared between children with different genetic risk of T1D.

\section{Material and methods}

The studies included in this thesis are population-based register studies, three case-control studies and one cohort study, using prospectively collected material from the Swedish medical birth registry (MBR) and the Swedish pediatric diabetes quality registry (SWEDIABKIDS), as well as information from the Swedish national cohort study Better Diabetes Diagnosis (BDD). The study population consists of children and adolescents (0-18/19 years) diagnosed with T1D Jan 2000-Oct 2012 and registered in SWEDIABKIDS ( $\mathrm{n}=9,376)$. All children with T1D were matched with four control children from the MBR with the same year and day of 
birth, same sex, and born in the same region of Sweden $(n=37,504)$. In study I, the entire study population was used but in study III twins were excluded $(\mathrm{n}=552)$. In study II, children for whom data on their mother's BMI in early pregnancy and GWG were available were included (3,231 children with T1D and 12,948 control children). In study IV, children with T1D who also participated in the BDD study were included (4,533 children).

\section{Results and conclusions}

Maternal overweight and obesity were associated with an increased risk of T1D in the offspring but were not more common among children with high or low genetic risk. Maternal BMI was also inversely associated with the age at onset of T1D in children with HLA-DQ8/X and/or HLA-DQ2/X. Neither GWG nor mode of childbirth had any obvious impact on the risk of developing T1D. Being born large for gestational age or with a birthweight $\geq 4,000 \mathrm{~g}$ (macrosomia) was associated with an increased risk of T1D and being born small for gestational age or with a low birthweight $(<2,500 \mathrm{~g})$ was associated with a decreased risk of T1D, irrespective of maternal BMI and diabetes. Comparing children with T1D and different HLA genotypes revealed a slight difference in birthweight between the HLA genotype groups. Children with HLA-DQ2/8 were more often born with macrosomia compared to children with HLA-DQ8/X. Children without either HLA-DQ2 or HLA-DQ8 (HLA-DQX/X) were more often born with a low birthweight compared to those with HLA-DQ2/8 and HLADQ8/X. Size for gestational age did not differ between the HLA genotype groups, and the effect of size for gestational age and birthweight on age at onset of T1D was ambiguous. The effects of the environmental risk factors identified in this thesis are generally weak and no clear conclusion on whether they are causative can be drawn. Yet since overweight/obesity and a high birthweight are common in the population, even a small increase in risk can result in many cases of T1D. Overweight/obesity and a high birthweight are also associated with other adverse health outcomes and they are, at least partly, modifiable. This motivates additional research regarding their involvement in T1D etiology as well as preventive actions against overweight and obesity in the population. 


\section{CONTENTS}

ABSTRACT

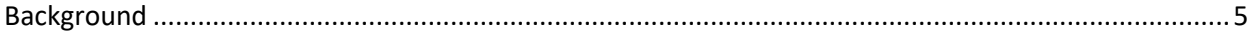

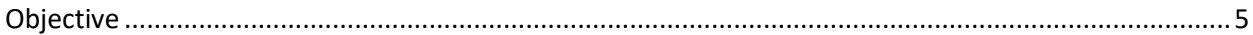

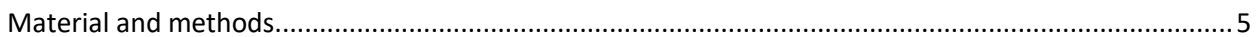

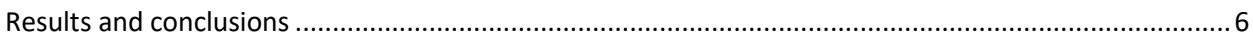

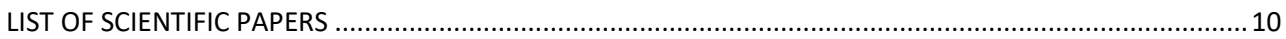

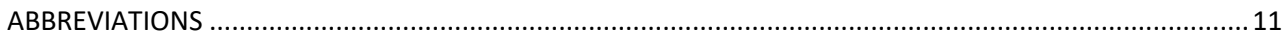

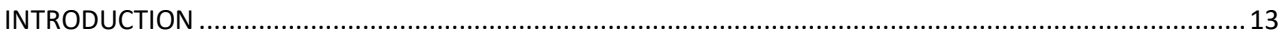

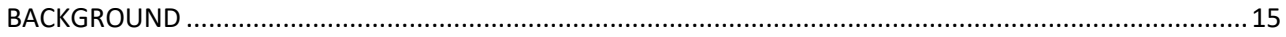

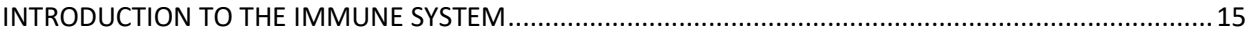

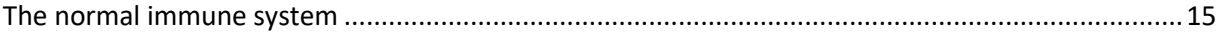

The human leucocyte antigen complex.............................................................................16

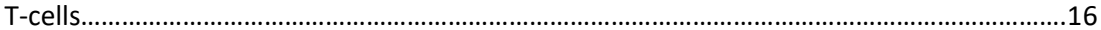

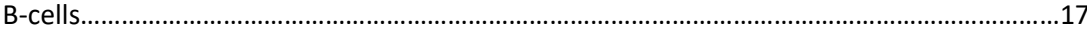

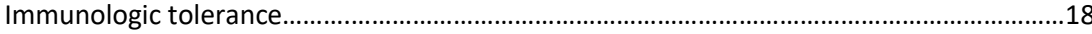

The immune system in autoimmune diseases.................................................................................... 18

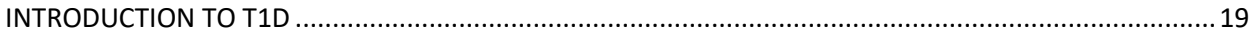

Symptoms, diagnostic criteria, and prognosis ................................................................................ 19

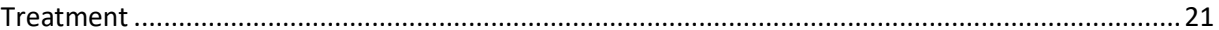

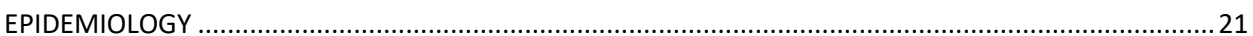

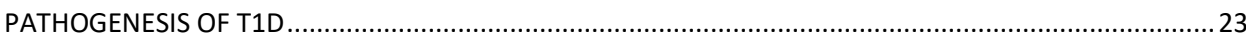

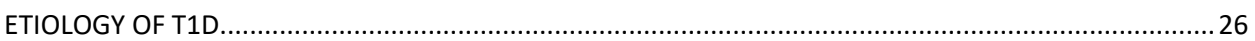

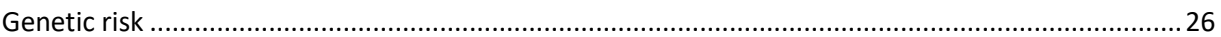

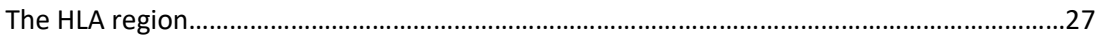

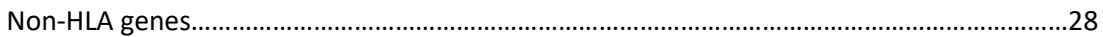

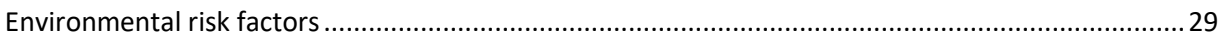

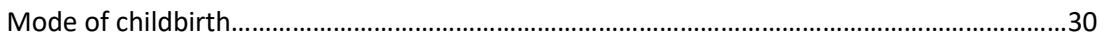

Maternal BMI and gestational weight gain..............................................................................34

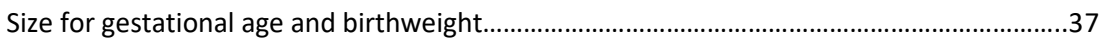

A connection between genetic and environmental risk factors ........................................................... 42

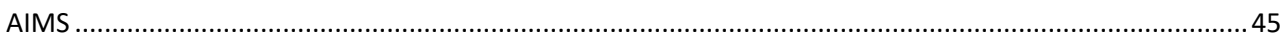

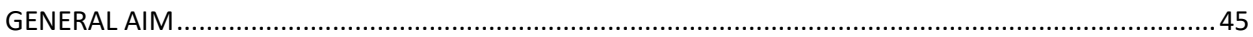

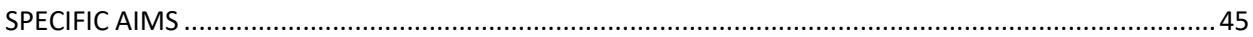

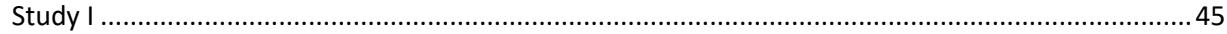

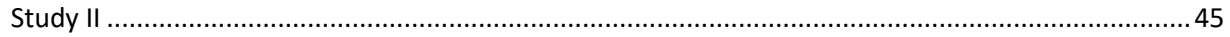




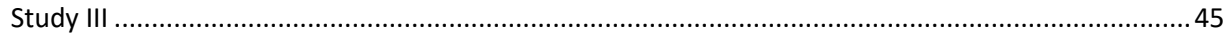

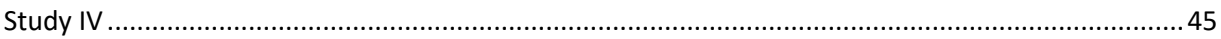

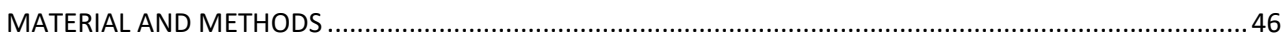

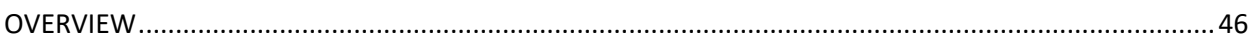

DATA SOURCES.

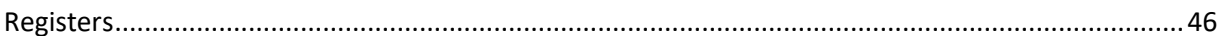

Swedish Medical Birth Register (MBR) ................................................................................46

Swedish Pediatric Diabetes Quality Register (SWEDIABKIDS).............................................47

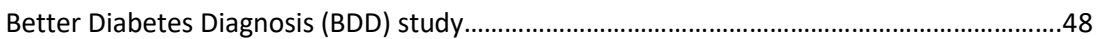

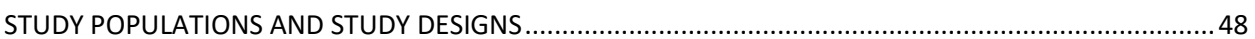

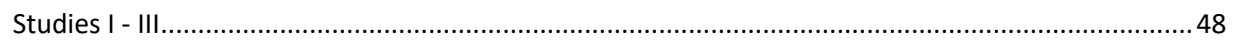

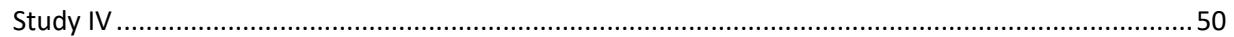

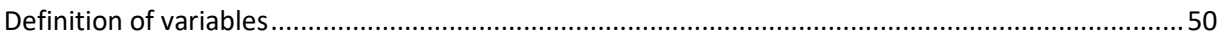

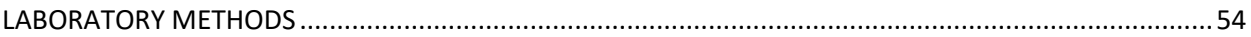

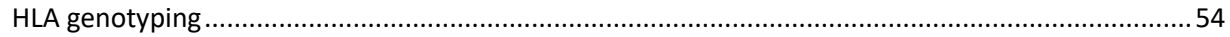

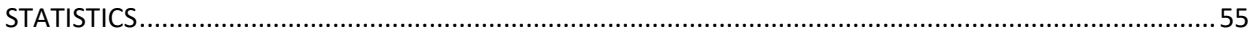

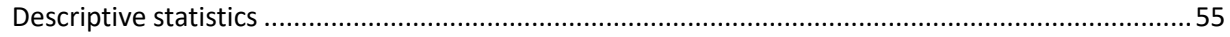

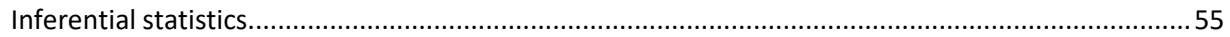

Statistical software

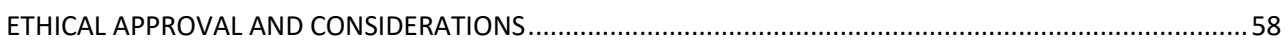

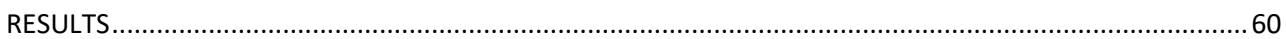

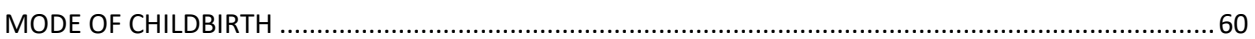

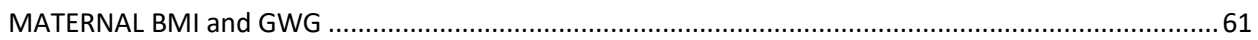

MATERNAL DIABETES

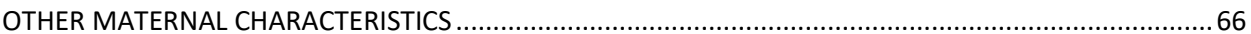

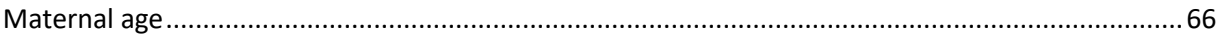

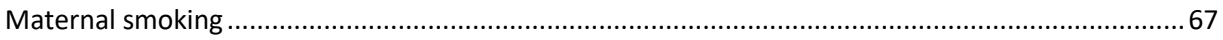

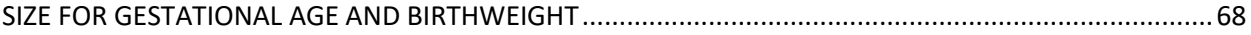

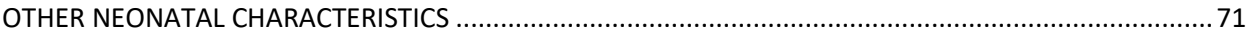

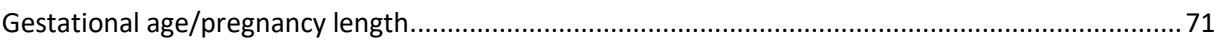

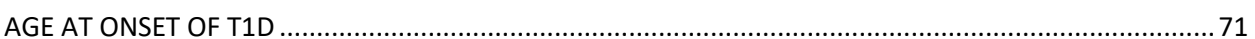

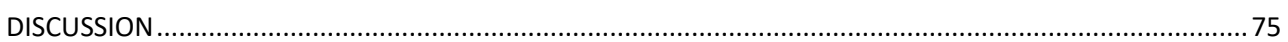

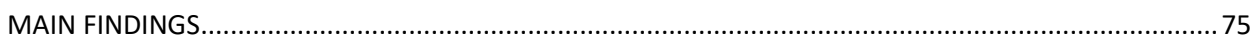

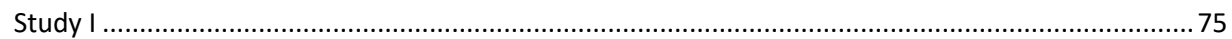

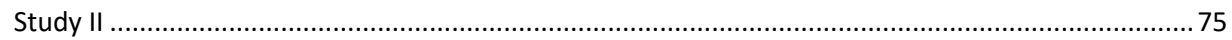

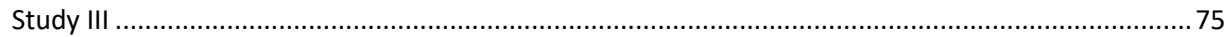




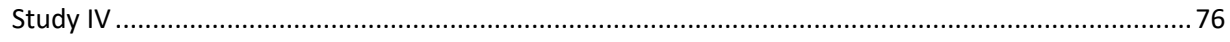

INTERPRETATION OF FINDINGS AND RELATION TO OTHER STUDIES ................................................ 76

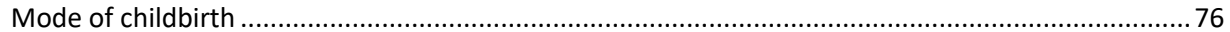

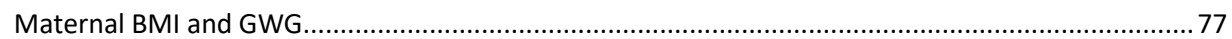

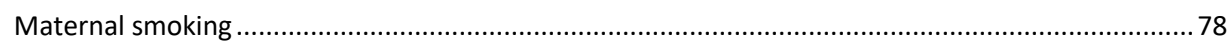

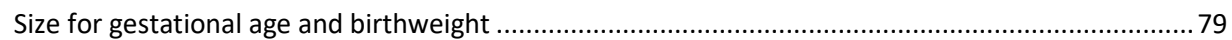

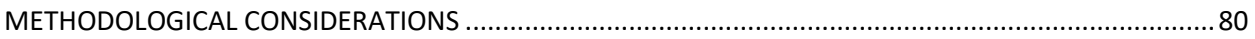

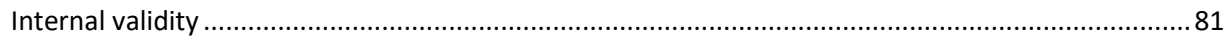

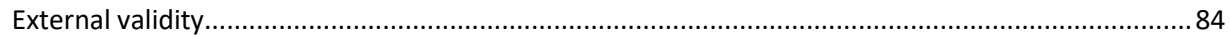

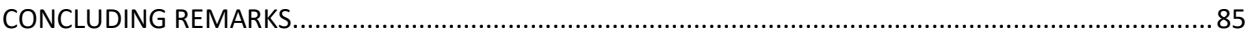

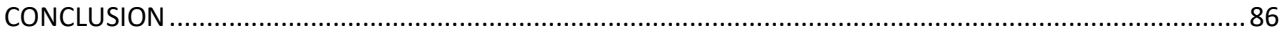

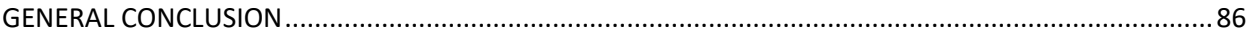

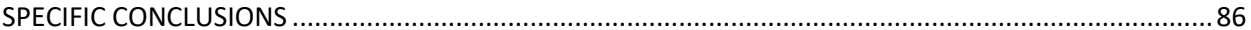

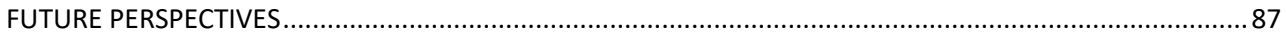

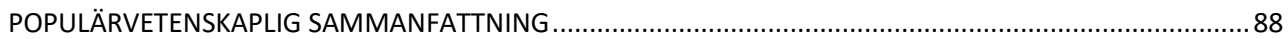

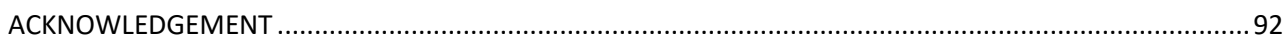

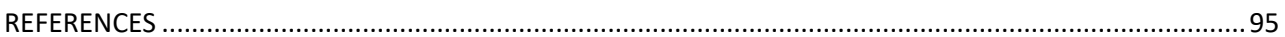

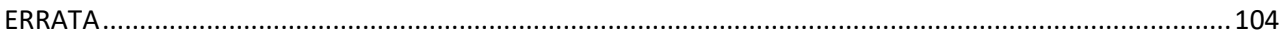


I. Caesarean section per se does not increase the risk of offspring developing type 1 diabetes: a Swedish population-based study

Ulf Samuelsson, Nina Lindell, Marie Bladh, Karin Åkesson, Annelie Carlsson and Ann Josefsson

Diabetologia, 2015;58:2517-24

II. Maternal obesity as a risk factor for early childhood type 1 diabetes: a nationwide, prospective, population-based case-control study Nina Lindell, Annelie Carlsson, Ann Josefsson and Ulf Samuelsson Diabetologia 2018;61:130-137

III. Size for gestational age affects the risk for type 1 diabetes in children and adolescents: a Swedish national case-control study

Nina Lindell, Marie Bladh, Annelie Carlsson, Ann Josefsson, Karin Åkesson and Ulf Samuelsson

Diabetologia 2021;64:1113-20.

IV. Maternal BMI is related to the age at onset of type 1 diabetes in children with different genetic risk - a Swedish national cohort Study

Nina Lindell, Ulf Samuelsson, Marie Bladh, Helena Elding Larsson, Gun

Forsander, Johnny Ludvigsson, Claude Marcus, Martina Persson, Karin Åkesson, Ann Josefsson, Annelie Carlsson.

In manuscript

Paper I is reprinted by permission of the publisher. Paper II and III are published as open access. 


\section{ABBREVIATIONS}

AGA

APCs

$\beta$-cell

B-cell

BCR

BDD study

B-glucose

BMI

CI

CS

DAMP

ER

GADA

GDM

GWG

HbA1c

HLA

HPA axis

IAA

IA2A

$\mathrm{Ig}$

IOM

IUGR

LGA

MBR

NK-cell

NOD mice

OR

PAMP

RCT

SD
Appropriate for gestational age

Antigen presenting cells

Beta-cell

Bone-marrow derived lymphocyte

B-cell receptor

Better Diabetes Diagnosis study

Blood glucose

Body mass index

Confidence interval

Cesarean section

Damaged-associated molecular patterns

Endoplasmic reticulum

Glutamic Acid Decarboxylase Autoantibodies

Gestational diabetes mellitus

Gestational weight gain

Glycated hemoglobin

Human Leukocyte-Antigen

Hypothalamic pituitary adrenal axis

Insulin autoantibodies

Insulinoma-associated Antigen 2 Autoantibodies

Immunoglobulin

Institute of medicine

Intrauterine growth restriction

Large for gestational age

Medical Birth Registry

Natural killer cell

Non-obese diabetic mice

Odds ratio

Pathogen-associated molecular patterns

Randomized controlled trial

Standard deviation 
SDS

SGA

SPSS

SWEDIABKIDS

T1D

$\mathrm{T} 2 \mathrm{D}$

T-cell

TCR

Th cell

Treg

ZnT8A
Standard deviation score

Small for gestational age

Statistical Package for the Social Sciences

Swedish Pediatric Diabetes Quality Register

Type 1 diabetes mellitus

Type 2 diabetes mellitus

Thymus-derived lymphocyte

T-cell receptor

Helper T-cell

Regulatory T-cell

Zinc Transporter 8 Autoantibodies 


\section{INTRODUCTION}

Diabetes mellitus affects more than 300 million people worldwide. Around $10 \%$ of these people are diagnosed with type 1 diabetes (T1D) and most of the rest with type 2 diabetes (T2D). There are also rarer forms of diabetes such as monogenic diabetes, neonatal diabetes, mitochondrial diabetes, and diabetes associated with cystic fibrosis, hemochromatosis, toxins, and drugs as well as diabetes during pregnancy ${ }^{1}$. Worldwide among children and adolescents, almost $90 \%$ have $\mathrm{T}^{2} \mathrm{D}^{2}$, and in Sweden it is almost $98 \%{ }^{3}$. T1D is a multifactorial, autoimmune disease in which genetic, environmental, and immunological factors are involved.

Diabetes was first mentioned in 1550 BC by an Egyptian physician, and the term diabetes was introduced by Aretaeus of Cappadocia (130-200) from the Greek word “diaba1'nein” (meaning passing through, referring to the patient's excessive amounts of urine). Avicenna (980 - 1073) divided the disease into two groups, the 'young and thin' and the 'old and obese', later termed T1D and T2D. In the $17^{\text {th }}$ century, Thomas Willis added the term 'mellitus' (Latin for sweet/honey) because of the sweet taste of the patient's urine, and in the $18^{\text {th }}$ century Matthew Dobson related the sweet urine to increased blood sugar (b-glucose). In 1869 Paul Langerhans identified islands of clear cells in the pancreatic tissue (later termed Langerhans islets) and in 1877 Etienne Lancereaux connected these islets with diabetes mellitus. In 1890, experiments in dogs led to the discovery that removing the pancreas leads to symptoms of diabetes, and death. Then in 1921, the discovery of insulin was made by Frederick Banting who, in collaboration with Charles Best, in John MacLeod's lab, showed that dogs with diabetes could survive for months with extracts from the Langerhans' islets. In January 1922, the first human, a 14-year-old boy dying from diabetes, received insulin and recovered. In 1923, Banting and MacLeod were awarded the Nobel Prize for the discovery of insulin 4 .

Since the discovery of insulin, much research has been done to further characterize, understand and treat T1D, and the understanding of the disease is much greater today than 100 years ago. Yet the cause of T1D is still unknown and there is no way to prevent or cure the disease, which means that T1D is still an important topic for current research. In the last few decades T1D incidence has risen very quickly, and this is thought to be attributed to environmental risk factors. Many develop the disease in childhood/adolescence and the disease process can start years before the clinical diagnosis, which makes environmental factors early in life interesting as potential risk factors. The aim of this thesis was to 
investigate environmental factors during pregnancy and in the perinatal period that could affect the risk of T1D in the child. 


\section{INTRODUCTION TO THE IMMUNE SYSTEM}

\section{The normal immune system}

The immune system is necessary to protect the body from the dangers of foreign agents, i.e., viruses, bacteria, pathogenic fungi and parasites. It consists of different white blood cells that all derive from a common hematopoietic progenitor cell in the bone marrow. These cells communicate with each other through different receptors on their surfaces as well as with small signaling molecules called cytokines (e.g., INF- $\gamma$, IL-2, IL-4, IL-10) and chemokines (chemotactic cytokines) $^{5}$.

The first line of defense is the innate immune system (also called natural or native immunity). It is unspecific, fast acting and can be divided into two parts. First, the mechanical, microbiological, and chemical barriers of the skin and in the mucosa of the respiratory, gastrointestinal, and urinary tracts that prevent pathogens from entering the body. Second, different immune cells, i.e., dendritic cells, natural killer (NK) cells, certain lymphocytes, macrophages and granulocytes (basophils, eosinophils, neutrophils and mast cells). The cells of the innate immune system can detect both pathogen-associated molecular patterns (PAMPs), i.e., products from pathogens, and damaged-associated molecular patterns (DAMPs), i.e., products from human cell damage, with their receptors. They elicit a fast, but general, immune response, which initiates inflammation through the release of cytokines and chemokines, thereby eliminating the pathogen/damaged cell. The innate immune system also activates the adaptive immune system ${ }^{5}$.

The adaptive immune system (also called specific or acquired immunity) is slower acting and more specific and consists of the thymus-derived lymphocytes (T-cells) and the bone marrowderived lymphocytes (B-cells). Antigen-presenting cells (APCs), for example dendritic cells, activated by a pathogen, travels to the lymph node and interact with the naïve lymphocytes. The lymphocytes have antigen-specific receptors and can only respond to the "right" antigen. When the lymphocyte is activated the T-cells mature into antigen-specific effector cells, often producing cytokines, and the B-cells turn into antibody-secreting plasma cells. Both cell types undergo clonal expansion, creating multiple cells with the same specificity. The adaptive immune system, unlike the innate, has a memory and the next time the same PAMP/DAMP is encountered the immune response is much faster acting 5 . 


\section{The human leucocyte antigen complex}

The major histocompatibility complex (MHC), which in humans is called the human leucocyte antigen (HLA) complex since they were first discovered on the surface of white blood cells, is crucial in the innate and adaptive immune system. Its function is to bind peptide antigens and display them to T-cells ${ }^{6}$. They can only bind one peptide at a time and all peptides that bind to a particular HLA molecule are structurally similar ${ }^{5}$.

The HLA locus on chromosome 6p21 contains both the class I (A, B and C) and class II (DR, DQ and DP) HLA genes. In between these is the class III region. The HLA region contains more than 250 genes and is the most polymorphic part present in the human genome ${ }^{7}$. The HLA genes encode cell-surface molecules that consist of an $\alpha$ - and a $\beta$-unit that form a heterodimer and have a peptide-binding cleft. The most extensive polymorphism in the HLA region encodes the sequence of the peptide-binding $\mathrm{cleft}^{5}$, thus influencing the repertoire of peptides that can bind to, and be presented by, the HLA molecule to the T-cells ${ }^{6}$.

The class I HLA genes form molecules that are expressed on all cells in the body, except red blood cells, and present endogenous peptide antigens to CD8+ T-cells. Class II HLA genes form molecules that can be found on APCs, B-cells and thymic epithelial cells and present exogenous antigens to $\mathrm{CD} 4+\mathrm{T}$-cells, thereby initiating an immune response ${ }^{6}$.

The set of HLA alleles present on each chromosome is called an HLA haplotype, and every person inherits one haplotype from each parent. Two haplotypes form a genotype and individuals express both their haplotypes, ensuring maximal polymorphism. Some alleles are inherited separately and randomly (i.e., at equilibrium) in the population but many are inherited together (i.e., linkage disequilibrium) ${ }^{5}$ which allows haplotypes to be assumed ${ }^{6}$. Initially, HLA variations were determined serologically and had a simple nomenclature (ex DR4) where the letter described the locus and the number a specific allele. Later, DNA-based genotyping led to a new nomenclature (ex DRB1*04:05) where the locus name is followed by an asterisk and then the numerical designation for the allele, first the group and then the individual allele. In 2010, the nomenclature was changed again, making allele designation even longer. Reporting of HLA data in studies is still a mix of these systems ${ }^{6}$.

\section{T-cells}

T-cells develop in the bone marrow and the immature T-cells subsequently migrate to the thymus where they undergo maturation by first positive and then negative selection. ${ }^{8}$ On their surface the T-cells have T-cell receptors (TCRs) that are heterodimers with a hypervariable 
region that denotes the specificity of each clonotype and comprises the antigen binding site ${ }^{9}$. The TCRs can bind to the HLA-complex on APCs. If a TCR can recognize the antigen, and bind to the HLA molecule, the cell survives positive selection. If a T-cell cannot bind to any HLA it dies. After positive selection the T-cell meets self-antigens, and if recognition and binding of the self-antigen occurs, the T-cell undergoes negative selection (dies by apoptosis $)^{8}$. However, some self-reactive T-cells survive and differentiate into regulatory Tcells (Tregs). This process is called central tolerance and ensures self-tolerance ${ }^{5}$ (see immunologic tolerance below).

The T-cells can be CD4-positive (CD4+) and bind to MHC/HLA class II molecules, or CD8positive (CD8+) and bind to MHC/HLA class I molecules ${ }^{5}$. When CD4+ T-cells are activated, they become helper T-cells (Th cells) or Treg. Th-cells can be divided into Th1, Th2 and Th17 cells. Activation of Th1 cells leads to the release of cytokines, which attracts macrophages and cytotoxic cells, and to cell-cell interactions. Th-cells also stimulate B-cells to produce immunoglobulin (Ig) $-\mathrm{G}$ antibodies. The cytokines released by Th1 for example INF- $\gamma$ are of great importance in cell-mediated immunity ${ }^{10,11}$.

\section{B-cells}

B-cells develop and mature in the bone marrow and then migrate to the spleen ${ }^{5}$. Their B-cell receptors (BCRs) are membrane-bound antibodies with, just like the TCR, a hypervariable region that denotes the specificity of each clonotype and comprises its antigen binding site 9 . When the immature B-cell recognize self-antigens, their receptors are either edited and get a new specificity, or if this fails, the B-cell is deleted (die) by apoptosis. If the self-antigen is only weakly recognized, the cell can become unresponsive (anergic) instead. (=central tolerance). When the B-cells recognizes an antigen, it is internalized and subsequently presented on HLA II molecules. This makes the Th-cells, with that particular specificity, bind to the B-cell, thereby activating the B-cell. The activated B-cell turns into a mature plasma cell that produces antibodies (with the same specificity as the receptor on the B-cell) . $^{5}$

Antibodies are immunoglobulins (Ig) and during the B-cell maturation billions of different antibodies are created. Antibodies can react with both foreign peptides (PAMPs) and our own proteins (DAMPs). There are five antibody isotypes $\operatorname{IgA}$, IgD, $\operatorname{IgE}, \operatorname{IgG}$ and $\operatorname{IgM}$, and they have different roles in the immune system. Antibodies that recognize self-antigens are called autoantibodies ${ }^{5}$. 


\section{Immunologic tolerance}

When the antigen receptors develop, the specificities of the receptors are random, i.e., not influenced by what is foreign/self ${ }^{5}$. Theoretically, up to $10^{18}$ different TCRs or BCRs can be generated in a person ${ }^{9}$. Some T- and B-cells in every individual may express receptors that can react to self-antigens and could cause disease. To prevent this the process of immunologic tolerance evolved ${ }^{8}$. Self-tolerance can be induced either in the immature lymphocytes in the bone marrow or thymus (=central tolerance), but since this process is not perfect, with the result that self-reactive lymphocytes can "escape" into the bloodstream, there is also the process of peripheral tolerance in mature lymphocytes in other parts of the body. Central tolerance is mostly for self-antigens as foreign (e.g., microbial) antigens are not present in the central lymphoid organs ${ }^{12}$.

Mature lymphocytes that recognize self-antigens are subjected to peripheral tolerance. The lymphocyte that responds/binds to an antigen in the absence of co-stimulation or innate immunity becomes either incapable of activation (=anergy) by re-exposure to that antigen or dies by apoptosis (=deletion). T-cells can also be suppressed by Tregs. Exactly how this happens is not known ${ }^{13}$.

\section{The immune system in autoimmune diseases}

In autoimmunity, self-tolerance fails, self-reacting lymphocytes are activated, and the resulting disease is called autoimmune disease ${ }^{13}$. The potential for autoimmunity exists in everyone because some of the randomly generated specificities of clones of developing lymphocytes may react to self-antigens. The autoimmune diseases may be systemic or organspecific $^{8}$ and are caused by an imbalance between lymphocyte activation and lymphocyte control, due to inadequate regulation or elimination of T- or B-cells ${ }^{14}$.

Factors that influence the development of autoimmunity are genetic susceptibility and environmental triggers. Changes in host microbiome and epigenetic alterations in immune cells may also contribute ${ }^{14}$. However, which tolerance mechanism fails in autoimmune diseases is not known ${ }^{13}$. There may be an abnormal display of self-antigens, either by antigens that are normally cleared or neo-antigens that have been structurally changed by enzymatic modifications, cellular stress or injury, to which the immune system is not tolerant. Cell injury or infection can also activate the innate immune system, resulting in inflammation, which could contribute to autoimmune disease, perhaps by causing excessive T-cell activation. Thcells are of special interest because they are the key regulators of all immune responses to 
proteins, and most self-antigens in autoimmune diseases are proteins. In addition, several autoimmune diseases are linked to HLA molecules. Th-cell abnormalities may also lead to autoantibody production as these cells are necessary for the production of high-affinity autoantibodies against protein antigens ${ }^{5}$.

In most autoimmune diseases the individuals inherit multiple genetic polymorphisms that contribute to disease susceptibility. The strongest associations are with HLA genes. The class II HLA-DR and HLA-DQ alleles are of particular interest because class II HLA molecules are involved in the selection and activation of CD4+ T-cells ${ }^{14,15}$. The CD4+ T-cells regulate humoral and cell-mediated immune responses to protein antigens. The genetic susceptibility subsequently interacts with environmental factors to cause the disease ${ }^{5}$.

Some polymorphisms are associated with several autoimmune diseases, whereas others are disease-specific ${ }^{16}$. Polymorphisms are also found in healthy individuals, and in studies monitoring individuals at risk of disease because of their HLA genotype, most will never develop the disease ${ }^{17,18}$. A particular HLA genotype is therefore not by itself the cause or predictor of any autoimmune disease, but may be one of several factors contributing to autoimmunity ${ }^{8}$.

\section{INTRODUCTION TO T1D}

\section{Symptoms, diagnostic criteria, and prognosis}

T1D accounts for around $10 \%$ of all diabetes ${ }^{19}$ and is usually diagnosed in children $<15$ years of age. In Europe, the most common age range for boys to be diagnosed with T1D is 10-14 years and for girls 5-9 years ${ }^{2}$. However, T1D can be diagnosed at all ages, though it is rarely diagnosed in children younger than one year old ${ }^{2}$. As opposed to almost all other autoimmune disorders, T1D does not affect more females but rather the opposite. In most countries there is a male sex bias, at least in older adolescents and young adults ${ }^{1}$, and in Sweden more boys than girls develop $\mathrm{T}^{3} \mathrm{D}^{3}$.

The patient presents with symptoms related to hyperglycemia i.e., polyurea (excessive urination), polydipsia (excessive drinking), nocturia (having to urinate during the night), enuresis (bedwetting), blurred vision, and behavioral disturbance. Weight loss is also a common symptom in young people and may be accompanied by polyphagia (excessive hunger). Chronic hyperglycemia or insufficient access to insulin can also impair growth and increase susceptibility to infections ${ }^{1}$. 
The most severe symptoms are ketoacidosis or non-ketonic hyperosmolar syndrome, and if the individual does not get the right treatment fast, they can lead to stupor, coma and death ${ }^{1}$. These potentially life-threatening complications can occur before diagnosis or at any time during the course of the disease when insulin levels are depleted. In Sweden around $25 \%$ of children present with ketoacidosis at the time of diagnosis ${ }^{3}$.

Until 1851 the diagnosis of diabetes was made by the physician tasting the urine (sweet taste) and though blood glucose (b-glucose) became a routine in the 1910s, samples had to be taken very near to the laboratory since preservatives were not introduced until $1931^{20}$. Today the diagnosis is based on one or more of the following 1 :

1. Classic symptoms of diabetes/hyperglycemia or hyperglycemic crisis and a plasma glucose $\geq 11.1 \mathrm{mmol} / \mathrm{L}$ or capillary $>12.2 \mathrm{mmol} / \mathrm{L}$,

OR

2. Fasting (no caloric intake for $\geq 8$ hours) plasma glucose $\geq 7.0 \mathrm{mmol} / \mathrm{L}$. OR

3. Two-hour postload glucose $\geq 11.1 \mathrm{mmol} / \mathrm{L}$ during an oral-glucose-tolerance test (OGTT) where the individual drinks $75 \mathrm{~g}$ (or $1.75 \mathrm{~g} / \mathrm{kg}$ of body weight, max $75 \mathrm{~g}$ ) anhydrous glucose dissolved in water. This test should only be performed when the diagnosis cannot be made easily by the other methods.

OR

4. Glycated hemoglobin $(\mathrm{HbA} 1 \mathrm{c}) \geq 6.5 \%$ ( $\geq 48 \mathrm{mmol} / \mathrm{mol})$. A value below does not exclude the diagnosis, and the role of $\mathrm{HbA1c}$ in diagnosing diabetes is not clear. Conditions that affect normal red blood cell turnover can affect the result with false high/low values.

In the absence of symptoms, two abnormal test results (from the same or different tests) are required to confirm the diagnosis.

After diabetes mellitus has been diagnosed, the next step is to differentiate between T1D, T2D, monogenic- and other forms of diabetes. The type of diabetes is typically based on the individual's characteristics at presentation. However, with the increasing prevalence of overweight and obesity (among other factors), the ability to make a clinical diagnosis has been hampered. Diabetes-associated autoantibodies (see below) are important in diagnosing T1D since one or more are present in $>90 \%$ of children with $\mathrm{T}^{1} \mathrm{D}^{1}$. 
In Sweden, all children newly diagnosed with diabetes are checked for autoantibodies, HLA genotype and C-peptide (a marker of residual insulin production) as part of the Better Diabetes Diagnosis (BBD) study ${ }^{21}$ (see method section).

There is no cure for T1D and before insulin it was rapidly fatal. However, even with insulin treatment T1D is a severe, chronic disease that can result in serious long-term micro- and macrovascular complications, i.e., blindness, cardiovascular disease, renal disease and footand leg amputation ${ }^{22-26}$. Patients with T1D have a reduced life expectancy because of these complications and due to the possibility of suffering acute diabetes coma ${ }^{27-29}$. In addition, people with T1D have increased risk of developing other autoimmune disorders such as celiac disease, vitiligo and hypo- or hyperthyroidism ${ }^{19}$.

\section{$\underline{\text { Treatment }}$}

Insulin is still the standard treatment for T1D, but since insulin was invented, major improvements have been made with new forms of insulin, i.e., human insulin, rapid- and long-acting insulin analogs. The administration of insulin with different pens and pumps has also improved, as well as b-glucose monitoring ${ }^{30}$.

In the future there are hopes of immunotherapies. Several have been tested in new-onset and preclinical T1D, with some showing promising results ${ }^{31}$. For example, the anti-CD3 monoclonal antibody Teplizumab, which works by inhibition of CD8+ T-cells, has proved effective in preserving insulin secretion ${ }^{32}$ and in delaying the onset of T1D in a phase IIstudy, by a median of 24 months at study end. However, the response to the immunotherapy differed among participants and for example those with HLA-DR4 and without HLA-DR3 had a better response ${ }^{33}$.

\section{EPIDEMIOLOGY}

Diabetes was an uncommon disease in the $19^{\text {th }}$ century, and though limited information exists from the first decades of the $20^{\text {th }}$ century, childhood diabetes was well recognized but rare and rapidly fatal. Mortality statistics from the US, Denmark, and Norway for 1900-1920 suggest an incidence range of 2-7/100,000/year under age 15. During 1920-1950 the limited data, mainly from Scandinavia, suggests a low and stable incidence, but an increased prevalence, due to survival with insulin treatment. The incidence showed an upturn from the 1950s in both the US, northern Europe and Sardinia, though incidence data remain scarce until the 1980s. In for example, Denmark, the incidence doubled over a 30 -year period from $1950^{20}$, and in Finland the incidence has increased five-fold since the $1950 \mathrm{~s}^{34}$. 
Among children and adolescents with diabetes the vast majority have T1D 2,3 . Annually it is estimated that approximately 96,000 children (0-15 years) develop T1D and worldwide more than 500,000 children and adolescents are living with the disease ${ }^{1}$. The incidence and prevalence vary greatly in the world and even within countries, as well as between different ethnic groups ${ }^{1}$. The highest incidence rates are observed in Finland, followed by Sardinia, Sweden and Kuwait ${ }^{35}$. In Europe the difference in incidence is roughly 20 -fold and correlates with the frequency of HLA susceptibility genes in the general population ${ }^{1}$. In Sweden almost 8,000 children ( $<18$ years) have diabetes, the vast majority T1D, and in 2019 the incidence was 41.1/100 000 children aged 0-9 years and 45.2/100,000 children aged 10-17 years ${ }^{3}$. In Asia, on the other hand, the incidence of T1D is very low, for example in Japan around 2/100,000 person-years and China (Shanghai) 3.1/100,000 person-years, and the HLA association is different from that of Caucasians ${ }^{1}$.

The incidence has increased over the last few decades in what can almost be described as an epidemic $^{2}$. During 1989-2003 the estimated annual increase in Europe was 3.9\% (95\% Confidence Interval [CI] 3.6\% - 4.2\%) and worldwide (1990-1999) $2.8 \%$ (95\% CI $2.4 \%-$ $3.2 \%$ ). Studies from the beginning of the $21^{\text {st }}$ century, however, showed a slowed incidence rate; in the US 2002-2012 1.8\% (95\% CI 1.0\% - 2.6\%), Canada 2002-2013 1.3\% (95\% CI $0.0 \%-2.5 \%$ ) and Australia 2000-2011 0.4\% (95\% CI 0.1\%-0.9\%). However, the opposite was found in a low-incidence region in China that had an annual increase of $12 \%$ (95\% CI $7.6 \%-16.6 \%$ ) during $2007-2013^{36}$. A Swedish study found that the incidence in children $<15$ years of age had the highest increase between 1999 and 2004 and this seemed to level off during $2005-2007^{37}$, but the incidence has remained fairly stable in recent years ${ }^{3,38}$. A study from Finland of the same age group found a modest increase in incidence in the period 19801988 and thereafter an annual increase of 3.6\% until 2005. This was followed by a plateau until $2011^{39}$. Another study from Finland found a decreased incidence rate between 2003 and 2018, mainly attributed to a decrease among the youngest children ${ }^{40}$. Also, another study from Norway, which investigated incidence between 1989 and 2012, had a similar result, with a 1.8\% increase in incidence 1989-1996, 3.4\% during 1996-2004 and only 0.3\% between 2004 and $2012^{41}$. In contrast the Eurodiab register with 84,000 children in 26 European centers (22 countries) showed a 3.4\% (95\% CI 2.8\% - 3.9\%) annual increase between 1989 and 2013. The lowest increase was in the period 2004-2008, but incidence almost returned to the same level as previously in the period after that. However, there was evidence of a slowing rate of increase in regions with the highest incidence ${ }^{36}$. More recently a study from New Zealand also 
showed an annual increase of 2.9\% (95\% CI 2.13\% - 3.48\%) from 1977 to 2006, but no significant change from 2006 to $2019^{42}$, and a study from Australia reported an annual decrease in incidence of T1D in children $<15$ years of age between 2002 and $2017^{43}$. Moreover, a study from Wales showed that the peak incidence was in 2010 and there was no increase in incidence thereafter ${ }^{44}$.

At the beginning of the $21^{\text {st }}$ century many countries reported the largest increase in incidence in the youngest (0-4 years) age group ${ }^{2,45-47}$. However, in the last few years high-incidence countries have reported a smaller increase in incidence, a plateau or at least a smaller increase in the youngest age group ${ }^{48,49}$. For example, the Swedish study mentioned above showed that during the 1990s the 0-4- and 5-9-year-olds had the highest relative increase in incidence, but thereafter it was in the 5-9- and 10-14-year age groups. Between 2005 and 2007 the two younger age groups had a decreasing average incidence compared to previous periods ${ }^{37}$. The study from New Zealand showed that the incidence increased consistently in the 5-9- and 1014-year-olds, but in the 0-4-year-olds there was an annual increase of $4.6 \%$ between 1977 and 2003 and no change after that ${ }^{42}$. Moreover, the Australian study found that the decrease in T1D incidence was accounted for by children aged 0-4 years ${ }^{43}$, and the same was true in the Finnish study, which found a decreased incidence rate among Finnish children $<7$ years of age between 2003 and 2018 (no significant change was seen among 7-14-year-olds) ${ }^{40}$. However, the Eurodiab study found that in nine centers there was a difference in increase rates in different age groups, and in six of those the highest rate of increase was found in the 0 -4-year-old age group ${ }^{36}$. Therefore, it is too early to say if the trend from high-incidence countries will continue or is temporary ${ }^{2}$.

A seasonal variation in incidence has also been reported, with most reporting a peak during winter. There are also reports of variations from year to year and in addition islet autoimmunity has been shown to have seasonal variation ${ }^{1,44}$.

\section{PATHOGENESIS OF T1D}

The pathogenesis of T1D is complex, and though it has been under thorough investigation for decades, there are still many unanswered questions. The disease is characterized by invasion of CD4+ and CD8+ T-cells in the islets of Langerhans leading to progressive destruction of the beta $(\beta)$-cells and insulin deficiency ${ }^{50,51}$. The loss of insulin leads to cells being unable to take up glucose, leading to elevated b-glucose and in the end starvation. 
The pathogenesis can be subdivided into three phases (Figure 1) starting with the occurrence of autoantibodies against pancreatic $\beta$-cell (islet) antigens. In the second phase there are autoantibodies present and a dysregulated glucose-metabolism, and in the third and final stage clinically overt T1D appears ${ }^{52}$.

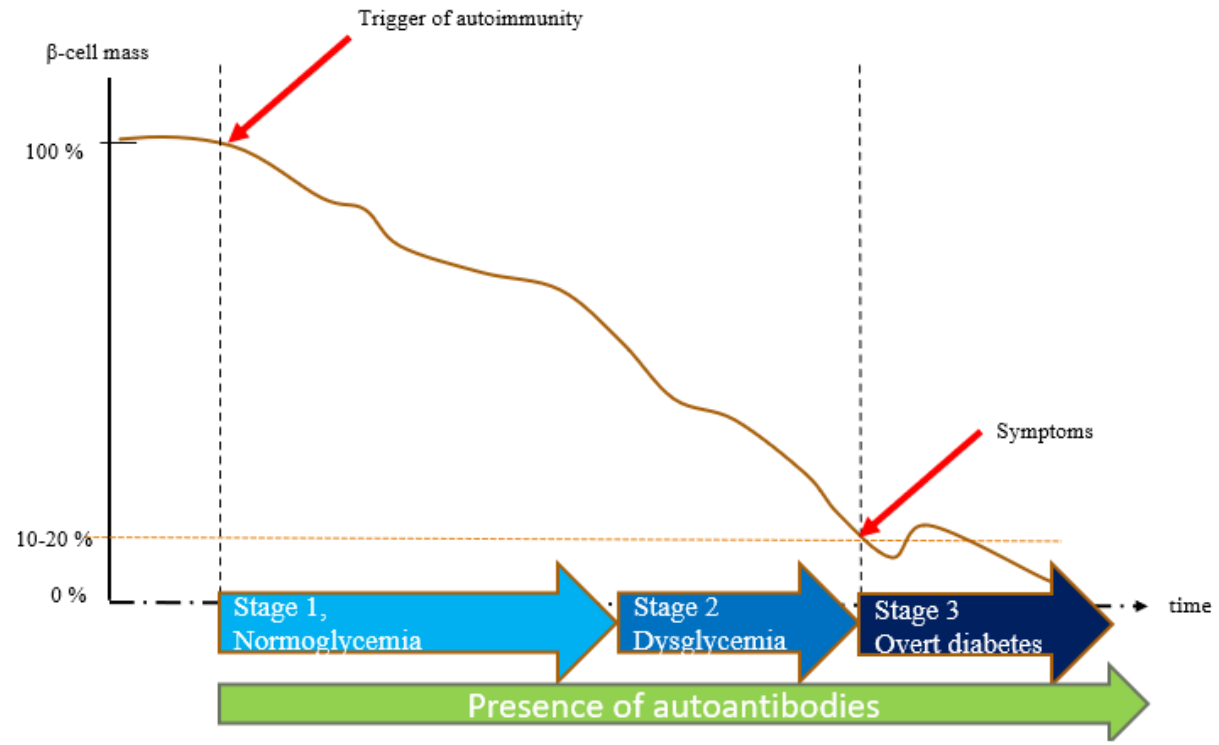

Figure 1 Pathogenesis of T1D. Modified from Insel at al ${ }^{52}$.

\section{The first stage}

The role of B-cells in T1D pathogenesis is still unclear though the autoantibodies found in T1D are the best and most reliable markers for prediction, and the first measurable sign of a pathological process ${ }^{53}$. The autoantibodies are directed against insulin (insulin autoantibodies [IAA]), glutamic acid decarboxylase 65 (GAD65, GAD autoantibodies [GADA]), insulinoma-associated antigen 2 (IA2, IA2 autoantibodies [IA2A]) or zinc transporter 8 (ZnT8 autoantibodies [ZnT8A]), which has three variants ${ }^{7}$. The first autoantibody is usually IAA or GADA and the peak incidence for IAA as the first autoantibody has been shown to be around one to two years of age and for GADA between two and five years of age ${ }^{17,18}$. Autoantibodies can remit/relapse and the time from first autoantibody to clinical onset of disease varies from months to years ${ }^{45}$. After two or more autoantibodies have appeared, $70 \%$ of children progress to clinical T1D within 10 years $^{54}$. And one or more autoantibodies are detected in more than $90 \%$ of patients with new-onset $\mathrm{T}^{5} \mathrm{D}^{55}$. 
The duration of stage 1 varies between individuals, from months to decades. Older age when first autoantibody appears, a slower progression from single to multiple autoantibodies and lower IAA titers are factors indicating delayed clinical onset. Genetics may or may not influence the progression ${ }^{7,19}$.

The inflammation, insulitis, seen in the pancreas, has been suggested to be a consequence of Th1/Th2 imbalance favoring Th1 ${ }^{56}$. Studies have shown that there are three hallmarks of the pancreatic islets in early T1D, overexpression of HLA class I, endoplasmic reticulum (ER) stress and $\beta$-cell apoptosis. It is believed that the ER stress contributes to increased apoptosis, inflammation, and modified autoantigen presentation ${ }^{57}$. The limited human histological evidence available suggests that insulitis is present only in a small proportion of autoantibodypositive individuals and that it emerges closer to the clinical onset ${ }^{58,59}$. It may therefore be that autoantibodies are present long before the insulitis. It is thought that CD8+ (cytotoxic) Tcells, CD4+ (T-helper) T-cells, NK-cells and macrophages contribute to the destruction of the $\beta$-cells ${ }^{60}$. Peripheral CD4+ and CD8+ T-cells with specificity for $\beta$-cell autoantigens are often found in persons at high risk of, or newly diagnosed with, $\mathrm{T}^{1} \mathrm{D}^{16}$. In addition to the adaptive immune system, the innate immune system also plays a part in T1D pathogenesis, for example by the actions of innate pattern-recognition receptors that promote the synthesis and release of pro-inflammatory mediators. Current evidence thus suggests that the onset of autoimmunity, indicated by autoantibodies, precedes the destruction of $\beta$-cells and loss of their function ${ }^{7}$, and that the autoimmunity may be triggered by the innate immune system ${ }^{61}$. A study showed that INF- $\alpha$, a cytokine, may be one of the molecules that induce the innate immune system. INF- $\alpha$ upregulated HLA class I molecules, inflammation and ER stress markers in human $\beta$-cells and acted with IL-1 $\beta$, another cytokine, to induce $\beta$-cell apoptosis. Other studies have shown that additional pro-inflammatory cytokines (IL-1 $\beta$, TNF- $\alpha$ and INF$\gamma)$ are also present in islet inflammation ${ }^{62}$.

Already in the first stage, fluctuations of insulin secretion can be detected, but b-glucose levels are normal ${ }^{7}$.

\section{The second stage}

The individual has developed impaired glucose tolerance due to the loss of functional $\beta$-cells, and this can be revealed by biochemical tests. However, there are no symptoms of hyperglycemia yet. Studies have shown that the deterioration of the insulin response seems to accelerate in the months before diagnosis. During this stage, an individual's HbA1c may gradually increase within the reference range ${ }^{7}$. 


\section{The third stage}

When insufficient $\beta$-cell mass remains, the individual develops symptoms of hyperglycemia and is diagnosed with $\mathrm{T}^{1} \mathrm{D}^{7}$. A small number of biopsy studies from individuals with newly diagnosed T1D ${ }^{63}$, or autopsy studies from individuals who died soon after T1D onset ${ }^{58,59}$, have shown that $80-95 \%$ of the $\beta$-cell mass is destroyed at onset of T1D. However, a metaanalysis of data obtained from autopsy studies of individuals who died soon after diagnosis found that the extent of $\beta$-cell loss varied with age. A more pronounced loss was seen in younger compared with older people, and at the age of 20 a $40 \%$ reduction was sufficient to cause T1D. Thus, the reduction of $80-95 \%$ of the $\beta$-cell mass might be an overestimate for most patients. A proposed reason for the age-dependent difference in the loss needed for diagnosis is the difference in need for insulin and body size. The body weight changes at a different rate than $\beta$-cell mass, and the "excess" $\beta$-cell mass therefore declines with age, i.e., as the body grows, more insulin is needed to give the same effect as in a smaller body. Therefore, a smaller reduction in insulin-producing cells results in a clinical onset of T1D for a larger body ${ }^{64}$. In line with this, result from studies of children at high genetic risk of T1D, showed that children with higher preserved C-peptide levels tend to be older at diagnosis and to have a higher BMI. Also, many children and adolescents experience partial remission after initiation of insulin treatment. This is attributed to transiently improved insulin secretion and peripheral insulin sensitivity, perhaps due to reversion of $\beta$-cell exhaustion. Retained $\beta$-cell function is associated with less severe hypoglycemia and reduced probability of long-term complications ${ }^{7}$. In some patients the insulitis may persist for years after T1D onset but decreases with duration of the disease, and seems to correlate with remaining $\beta$-cells ${ }^{59}$.

\section{ETIOLOGY OF T1D}

The etiology of T1D is complex and depends on both genetic and environmental factors.

\section{Genetic risk}

The genetic background to T1D is complex and lacks a clear pattern of inheritance. This is illustrated by the fact that, though familial aggregation affects the risk, $80-90 \%$ of those diagnosed with T1D do not have a first degree relative with the disease. According to the international society for pediatric and adolescent diabetes, the lifetime risk of T1D in the general population is $0.5 \%{ }^{45}$ and in Sweden it may be more than $1 \%{ }^{65}$. Yet, siblings of children with T1D have a lifetime risk of developing T1D of almost 10\%, and offspring of fathers with T1D have a higher risk $(3.6-8.5 \%)$ of T1D than offspring of mothers with T1D $(1.3-3.6 \%)^{45}$; the cause of this discrepancy is unknown. Studies on monozygotic twins have 
showed that the accumulative risk of T1D for the unaffected twin is $<40 \%{ }^{66,67}$, but it may be higher $(>50 \%)$ with long-term follow up ${ }^{68}$.

In total more than 50 gene loci have been implicated in the genetic risk of T1D, explaining about $80 \%$ of its inheritability ${ }^{69}$. About $50 \%$ of the genetic risk is conveyed by HLA class II genes, and variants of other genes only make smaller individual contributions to the risk.

Some genetic factors may also be important for the appearance of a first autoantibody rather than symptomatic $\mathrm{T}^{1} \mathrm{D}^{7}$.

\section{The HLA region}

A strong HLA association with T1D was reported as early as $1974^{70}$, and with time the extensive heterogeneity of the HLA component has emerged ${ }^{6}$. Certain variants of the HLA class II genes affect the risk of $\mathrm{T}_{1} \mathrm{D}^{15,71}$, as well as the first-appearing autoantibody ${ }^{17}$, and particular combinations can increase or decrease the risk of $\mathrm{T}_{1} \mathrm{D}^{71}$. The strongest associations are with the HLA-DR3-DQA1*05:01-DQB1*02:01 (also termed DR3-DQ2) and the HLADR4-DQA1*03:01-DQB1*03:02 (DR4-DQ8) haplotypes ${ }^{72}$. The highest risk occurs with the simultaneous presence of both (DQ2/8), and this genotype has an odds ratio (OR) for T1D of between $11^{73}$ and $21^{74}$ and is more often found in children diagnosed at a younger age ${ }^{73,75}$. The second highest risk genotype is DQ $8 / 8^{76}$.

The incidence of T1D in children with DQ2/8, in a British population, was $5 \%$ by the age of $15^{74}$. HLA-DQ2 was the most common haplotype and is found in $12.5 \%$ of the general population and $34 \%$ of individuals with $\mathrm{T}^{1} \mathrm{D}^{15}$. The BDD study in Sweden, a cohort study of newly diagnosed children with T1D, found that eight genotypes accounted for $67 \%$ of the cohort, compared to $16 \%$ of the general population ${ }^{73}$. Nearly $90 \%$ of Scandinavian children diagnosed with T1D have at least one of the DQ2 or DQ8 haplotypes ${ }^{71}$. There are also intermediate risk and low-risk HLA genotypes (the latter with OR below 1$)^{73}$. In recent years a shift from the highest risk HLA genotype to more intermediate and low-risk genotypes, has been seen in children newly diagnosed with $\mathrm{T}_{1} \mathrm{D}^{73,77}$. In addition, a study has shown an increased proportion of overweight children within the DQ2/2 genotype ${ }^{73}$.

The HLA genotype is important for the etiology and maybe for the pathogenesis of T1D. The polymorphism and linkage disequilibrium have made it challenging to identify associations with first-appearing autoantibodies ${ }^{7}$. Yet individuals with HLA-DR4-DQ8 have been shown to more often have IAA as the first-appearing autoantibody, while individuals with HLA- 
DR3-DQ2 have GADA ${ }^{17,78}$. Also, other HLA class II molecules, like HLA-DRB3, -DRB4 and -DRB5, could be associated with $\beta$-cell autoimmunity ${ }^{72}$.

Transgenic animal models indicate that MHC class II can have an effect on the T-cell repertoire by influencing the positive and negative selection in the thymus. This affects both the CD4+ and CD8+ T-cell repertoire by positive selection of autoreactive T-cells (genes with increased susceptibility) or negative selection of diabetogenic T-cells and/or selection of Tregs (genes with decreased susceptibility) $)^{79}$.

Some HLA class I variants also affect the risk of T1D, or maybe rather the age at onset of the disease, and the variant most widely associated with T1D is HLA-B*39:06 whereas HLA$\mathrm{B} * 57: 01$ decreases the risk $^{80}$.

The HLA class III region does not encode any classical HLA loci, but is one of the most genedense regions and codes several proteins that are important to the immune system (such as components of the complement cascade), inflammation and cell stress (e.g., TNF- $\alpha)^{6}$. A genome-wide association study reported associations with T1D, but earlier studies of candidate genes have given disparate results ${ }^{7}$.

\section{Non-HLA genes}

In addition to HLA genes, several other non-HLA genes are involved in the inheritability of T1D. However, each of these gene loci adds very weakly to the total genetic risk ${ }^{72}$, and for most of the loci the molecular mechanism of action remains undefined ${ }^{72}$. It may also be that non-HLA genes only modify disease risk in individuals with certain HLA genotypes ${ }^{7}$.

After the HLA genes, the insulin gene (INS) on chromosome 11p15 has the strongest association with $\mathrm{T}^{8} \mathrm{D}^{81}$. INS codes the preproinsulin molecule, which is converted to proinsulin and subsequently to insulin and c-peptide ${ }^{82}$, and is unique in susceptibility genes as it codes for a known autoantigen ${ }^{7}$. Expression levels of the INS are regulated partly by a direct transcriptional influence of a polymorphic insulin gene variable number of tandem repeats (INS-VNTR) which is associated with the proinsulin gene promoter region. A wide range of repeats have been observed but tend to cluster in different numbers of repeats (26-63 repeats [short]; class I alleles or 141-209 repeats [long]; class III alleles, and intermediate class II alleles) ${ }^{83}$. Class I confers susceptibility to T1D and class III protection, and the INSVNTR I/I genotype accounts for about $10 \%$ of the familial clustering of T1D ${ }^{82}$. Proinsulin is present in the thymus under the genetic control of the INS promotor region, and insulin transcription is higher in VNTR I/III or III/III compared to I/I. Those with the VNTR III 
genotype, compared with those with the I/I genotype, have been shown to have a more preserved $\beta$-cell function, lower frequencies of insulin autoantibodies and a lower concordance rate of diabetes among twins. The VNTR III genotype has been shown to modify disease risk even in those with high-risk HLA genotypes ${ }^{83}$.

After the INS gene, the PTPN22 and IL2RA genes have the strongest influence on T1D risk. PTPN22 encodes a protein involved in TCR signaling and a gain-of-function mutation is associated with T1D. It is proposed that the mutation promotes autoreactive T-cell survival. IL2RA encodes the IL-2 receptor subunit $\alpha$ which is expressed on lymphocytes ${ }^{7}$. There are also associations between non-HLA genes and the first-appearing autoantibody, for example INS with IAA ${ }^{18}$. In addition, there are a few other candidate genes that are thought to be causal, or in strong linkage disequilibrium with causal variants, but for others more studies are needed $^{72}$.

Most of the susceptibility genes seem to act multiplicatively with other loci on the risk of disease, except for the joint effect of HLA and PTPN22, which is significantly less ${ }^{7,84}$. Some of the genetic susceptibility variants are shared with other autoimmune disorders, though some are concordant and others discordant ${ }^{7,72}$.

\section{Environmental risk factors}

The lack of a high concordance between monozygotic twins and the fast increase in incidence suggests the influence of environmental or epigenetic factors on the risk of developing $\mathrm{T}_{1} \mathrm{D}^{7,85}$. Epidemiological studies have also shown that offspring of immigrants moving from low- to high-incidence countries have an increased incidence of T1D, and with time the incidence is close to that of the new country ${ }^{55,86}$. In addition, the fast increase in incidence is believed to be too quick to depend on a genetic shift and is therefore believed to be due to environmental factors. Environmental factors may have separate effects during the different stages of the T1D pathogenesis, with some triggering $\beta$-cell autoimmunity and the first autoantibody and others the progression to overt disease ${ }^{87}$.

Many different environmental factors have been suggested. Infectious agents are among the most extensively studied and are believed to contribute to the etiology. Other environmental factors that have been implicated are vitamin D, the introduction of cow's milk, duration of breastfeeding, psychological stress, rapid growth, overweight, trauma and toxins ${ }^{7,85}$. However, studies have provided conflicting evidence, which might be due to insufficient power or to the fact that they were done in genetically different populations ${ }^{85}$. There are currently several 
large, prospective studies of environmental determinants of T1D and efforts to try preventive interventions ${ }^{7,88}$. Most of these cohort studies are being performed on children at high genetic risk of T1D, for example The Environmental Determinants of Diabetes in the Young (TEDDY) study ${ }^{17}$, the Trial to Reduce Insulin Dependent Diabetes Mellitus (IDDM) in the Genetically at Risk (TRIGR) ${ }^{89}$, the BABYDIAB study ${ }^{54}$, the Diabetes and Autoimmunity Study in the Young (DAISY) ${ }^{87}$ and the type 1 Diabetes Prediction and Prevention (DIPP) study ${ }^{18}$. However, the All Babies in Southeast Sweden (ABIS) ${ }^{90}$ study is, in contrast, a large cohort study of the general population.

Environmental risk factors related to pregnancy and the perinatal period are of interest as many children develop T1D at a young age, and the process of autoimmunity starts before the clinical diagnosis. Perinatal risk factors have been investigated in many studies and associations have been found with many variables, for example Rubella and enterovirus infection during fetal life, blood group incompatibilities, maternal preeclampsia, maternal age, birth order, gestational age, and birthweight ${ }^{91,92}$. A meta-analysis from 2008 of 20 studies found an overall statistically significant association between T1D and cesarean section, older maternal age at delivery, shorter gestational duration and higher birthweight. However, there was evidence of heterogeneity, and many included studies did not show a significant result by themselves ${ }^{93}$. In addition, the reported associations have generally been weak, and identification and confirmation of environmental risk factors therefore remain a formidable challenge ${ }^{94}$.

There are several proposed hypotheses for how environmental factors could contribute to the development of T1D. Some are more general, and others pertain to a certain environmental risk factor. The hypotheses are not mutually exclusive and some overlap and intersect with each other.

Below, the environmental factors of most interest for this thesis will be described in more depth, as will the hypotheses pertaining to these factors.

\section{Mode of childbirth}

Cesarean section (CS) is the oldest operation in the field of abdominal surgery and is used for delivering the neonate (and placenta) through an incision in the abdominal wall and uterus. CS can be performed as a medical necessity or without medical indication. As the latter have been increasing, numerous studies investigating long-term consequences in children born by CS have been performed. Associations between birth by CS and morbidities such as obesity, 
asthma, and various forms of dermatitis ${ }^{95}$ as well as allergies, celiac disease and T1D have been found ${ }^{96}$.

In the same time period as the incidence of T1D has increased, there has been a parallel increase in the rate of CS. In 2002, the global rate was estimated to be $15 \%{ }^{97}$ and in 2018 it was $21.1 \%{ }^{98}$. The rate of CS differs substantially between different parts of the world, with higher rates in developed countries, Latin America and the Caribbean, and lower rates in other developing countries ${ }^{97,98}$. The average global annual increase in CS was $4.4 \%$ between 1990 and 2014. However, countries like China and Brazil, with high CS rates, still have a low incidence of T1D (1.01 and 12.8/100,000 person-years respectively $)^{99}$.

\section{Previous studies}

Several studies, many of them rather small, have investigated the relationship between CS and T1D but the results have been conflicting. An increased risk has been found in a case-control study from Scotland and Northern Ireland, which was most evident for children born with elective CS. They found no increased risk with assisted vaginal delivery ${ }^{100}$. A large Swedish cohort study, with a sibling design, found that the risk of T1D was moderately increased among those born by elective CS (relative risk (RR) 1.15 [95\% CI 1.06 - 1.25]) but not acute CS. They also found an increased risk with assisted vaginal delivery. However, in their sibling analysis the associations were no longer significant, which suggests that familial confounding (family diet, lifestyle, genes) accounts for the elevated risk and not a causal effect of $\mathrm{CS}^{101}$. Moreover, a meta-analysis by Cardwell et. al. from 2008 including 20 observational studies, with a total of 9,938 cases, showed an increased risk of T1D for children born by CS, where the adjusted OR was $1.19(95 \% \text { CI } 1.04-1.36)^{102}$. However, quite a few studies have found no association between CS and T1D, including a large Norwegian cohort study ${ }^{103}$, a Swedish case-control study with cases diagnosed from $1978-88^{104}$, a case-control-study from seven European countries ${ }^{91}$, a Danish case-control study ${ }^{92}$, an Australian cohort study ${ }^{105}$, a Canadian case-control study ${ }^{106}$ and a Swedish cohort study ${ }^{107}$. Some of these studies found an increased risk with CS in the unadjusted analyses but not when adjusting for confounders.

\section{Explanatory hypotheses}

There are different hypotheses as to why and how CS could increase the risk of T1D. One is the Hygiene hypothesis, which states that the decrease in frequency of, or delayed exposure to, certain infectious diseases accounts for the increase in atopic disorders (i.e., asthma, hay fever and eczema) ${ }^{108,109}$. The incidence of these disorders has, just like T1D, risen during the second half of the $20^{\text {th }}$ century, and their highest rates are in those with a relatively wealthy 
life style, living in temperate climates ${ }^{110}$. In the early 2000 s, the Hygiene hypothesis was extended to include autoimmune diseases ${ }^{108}$.

Epidemiological studies have shown that autoimmune diseases are more common in families with few children and a high socioeconomic background ${ }^{108}$. Genetics cannot explain this, as people migrating into high-incidence countries develop diseases with the same frequency as in the host country. And at least for T1D it does not seem that the climate can account for this effect, as Finland has a much higher incidence of T1D than Russian Karelia, though the locations have the same climate and genetic factors. However, the socioeconomic levels differ. Since the incidence of T1D is different between the two, but there is no difference in autoantibody positivity ${ }^{111}$, it implies that the Hygiene hypothesis applies more to the progression, than the trigger, of the autoimmune process ${ }^{108}$.

Early childhood infection with cytomegalovirus (CMV) has been associated with decreased incidence of $\mathrm{T}^{1} \mathrm{D}^{108}$. Moreover, non-obese diabetic (NOD) mice, one of the most widely used animal models in autoimmune diabetes, are more likely to develop diabetes when reared in a sterile environment ${ }^{110}$. Early repeated infections are believed to contribute to the development of the gatekeepers of the immune system (i.e., Tregs and other IL-10 producing cells) and without such stimulation, an altered immune response could develop and cause autoimmune or allergic disease ${ }^{109}$.

The Hygiene hypothesis has also been extended (Extended Hygiene hypothesis) to include the gut microbiota. It proposes that rather than waiting for exposure to pathogens, the infant gathers a microbiota from the mother and surrounding environment that may be important in protecting the child from diseases ${ }^{112}$ like allergies, T1D and obesity ${ }^{108}$.

As a result of changes in nutrition and the use of antibiotics, there has been a significant change in the human gut microbiota during the last century ${ }^{7}$. The bacterial colonization begins very early, when a fetus is in the uterus, but the infant's intestinal microbiota is established after birth. It goes through changes first during the lactation period and then again with the introduction of solid foods, resulting in a stable adult-type gut microbiota at around age three. The early composition of the intestinal microbiota is affected by several factors such as mode of childbirth, formula feeding vs breastfeeding, antibiotics, timing of introduction of solid foods and duration of breastfeeding. The intestinal bacteria are necessary for normal immune system development, for example the differentiation of T-cells (into Tregs and Th-cells) and B-cells ${ }^{113}$. Studies have shown immunological alterations early after birth by $\mathrm{CS}^{114}$. Since the 
composition of the gut microbiota in the first month of life is essential for the development of a healthy immune system ${ }^{109}$, alterations in this period might have consequences for the future health of the newborn ${ }^{114}$ and might lead to immune disorders later in life ${ }^{115}$. A study of children at high genetic risk of T1D showed that children born by CS had a weaker response to a tetanus vaccination, both a weaker cellular response and lower cytokine release, than those born vaginally. The authors concluded that this points to an overall hypo-inflammatory state in children born by $\mathrm{CS}^{114}$. In addition, in NOD mice, the administration of oral antibiotics to mothers and newborns led to destruction of their gut microbiota and increased the frequency of $\mathrm{T}_{1} \mathrm{D}^{108}$.

Studies have shown that children born by CS have a different gut colonization/intestinal microbiota compared by those born vaginally ${ }^{115,116}$, and that those born by CS have a more slowly diversifying microbiota. A study on seven-year-old children found that the microbiota was still slightly different between children born by CS or by vaginal birth. The latter had more clostridia, but no other significant differences were found ${ }^{117}$. Another study comparing the two modes of childbirth found that the difference in microbiota was most pronounced in the first month of life and at one year it was no longer apparent. When comparing acute and planned CS they also found that the pattern of gut colonization differed between the two ${ }^{115}$. One study found that the new-born harbored bacterial communities that were essentially homogeneous regardless of body compartment, and that the primary determinant of that bacterial community was decided by the new-born's mode of childbirth. Those born vaginally had a bacterial community most similar to the vaginal communities of their mothers, and those born by CS harbored bacterial communities most similar to the skin communities of their mothers. However, there was a strong coherence between the bacterial community in mother and child for those born vaginally, but skin bacterial communities of mothers giving birth by $\mathrm{CS}$ were no more similar to their own babies than to other babies born by $\mathrm{CS}^{116}$. Some studies suggest that the diversity of the microbiome is reduced in autoantibody-positive individuals who progress to $\mathrm{T}_{1} \mathrm{D}^{7,108}$, and a Finnish study found that the microbiome differed prior to autoimmunity in children at high risk of $\mathrm{T}^{1} \mathrm{D}^{118}$.

Other theories are related to the fact that children born by CS endure considerably less stress compared to children born vaginally. Studies have shown that children born by elective CS have a lower stress response, as measured by catecholamines, compared to children born vaginally. If the CS is acute the level of catecholamines is only slightly less than with vaginal childbirth $^{119}$. The Epigenetic Impact of Childbirth (EPIIC) hypothesis states that reduced 
levels of cortisol, adrenaline and oxytocin produced during labor could lead to fetal epigenomic remodeling anomalies (pathological priming), which affects the gene expression. Each cell in our bodies has the same DNA and genes, but their expression can vary depending on epigenetic regulation. DNA methylation is a specific epigenetic alteration, and the normal DNA methylation is necessary for differentiation of cell types. DNA methylation patterns are known modulators of immune function, and alterations could affect immune development and the immune system's response to antigenic exposures later in life. The methylation related to programming of the immune system appears to be especially susceptible to alterations early in life. Reprogramming could manifest as diseases later in life ${ }^{112}$. The physical stress during labor, something infants born by CS are deprived of, is also important for infant development and may facilitate programming of the hypothalamic pituitary adrenal (HPA) axis ${ }^{96}$. Studies have shown that CS affects the HPA axis, one of the primary stress regulatory systems, where cortisol is the end-product. Dysregulation of the HPA axis increases the risk of immune dysfunction and metabolic disease, since cortisol is necessary for the development of several organs, including the liver and pancreas. CS has been shown to disrupt cortisol production, with lower cortisol levels in cord-blood compared to vaginally born children ${ }^{96}$. Cortisol has also been shown to differ at 72 hours, eight weeks and sex months between children born by CS and vaginal birth. In the latter study they found lower cortisol levels both at baseline and after a stressful (pain) event in children born by CS. Those with elective CS without medical indication had even lower cortisol levels than those with medical indication. Long-term hypocortisolism may lead to long-term health risks ${ }^{96}$.

\section{Hypothesis}

The hypothesis (study I) was that being born by CS increases the risk of T1D.

\section{Maternal BMI and gestational weight gain}

In parallel with the increased incidence of T1D, there has been an increase in obesity in the general population worldwide. In the US almost $35 \%$ of women aged 20-39 are obese ${ }^{120}$ and $48 \%$ of $\mathrm{US}^{121}$ and one third of Australian women start their pregnancy being overweight or obese $^{122}$. In Sweden the number of pregnant obese women has doubled since the 1990s and in $2013,25 \%$ were overweight and $13 \%$ obese in early pregnancy ${ }^{123}$.

A high maternal pre-pregnancy body mass index (BMI) and a large gestational weight gain (GWG) have been connected to poor pregnancy outcomes and later health of the child ${ }^{124,125}$. In 2009, the Institute of Medicine (IOM) in the United States and the US National Research Council ${ }^{126}$ therefore published new guidelines describing appropriate GWG intervals for each 
BMI class (Table 1). Weight gain within these recommendations is categorized as adequate, below as inadequate, and above as excessive.

Table 1 Definition of BMI and appropriate GWG

\begin{tabular}{lll}
\hline $\begin{array}{l}\text { Pregestational BMI } \\
\text { category }\end{array}$ & BMI $\left(\mathbf{k g} / \mathbf{m}^{2}\right)$ & Recommended total weight gain $(\mathbf{k g})$ \\
\hline Underweight & $<18.5$ & $12.5-18.0$ \\
Normal weight & $18.5-24.9$ & $11.5-16.0$ \\
Overweight & $25.0-29.9$ & $7.0-11.5$ \\
Obese & $\geq 30.0$ & $5.0-9.0$ \\
\hline
\end{tabular}

Women tend to increase their BMI with age $\mathrm{e}^{127}$ and maternal BMI also increases with parity ${ }^{128}$. Maternal BMI affects the risk of gestational diabetes mellitus (GDM) and has been shown to affect the $\mathrm{GWG}^{129}$. GWG also increases with pregnancy length.

\section{Previous studies}

Studies have shown a correlation between a high maternal pregestational BMI, a high GWG and a subsequent risk of obesity, insulin resistance and T2D in the offspring ${ }^{130-132}$. Parental BMI has also been shown to affect risk of obesity in childhood. Maternal obesity increased the risk more than paternal obesity, but the highest OR for obesity at 7 years was having two obese parents ${ }^{133}$. A few studies have investigated maternal BMI and/or GWG and subsequent risk of $\mathrm{T} 1 \mathrm{D}$, with conflicting results.

A case-control study from Washington state, US found that maternal obesity increased the risk of offspring T1D (OR 1.29 [95\% CI 1.01 - 1.64]), but the study did not adjust for other variables $^{134}$. A large Swedish cohort study also found an increased risk of T1D in the offspring with maternal overweight and obesity (Incidence rate ratio [IRR] 1.35 [95\% CI 1.22 - 1.49]) if the mother did not have diabetes. However, for offspring of mothers with any type of diabetes, maternal obesity instead reduced the risk (IRR 0.58 [95\% CI $0.41-0.82]$ ), but the effect was not seen in children to mothers with either T1D or GDM ${ }^{107}$. There are also studies that have found no association, including two smaller case-control studies from Scotland ${ }^{135}$ and England ${ }^{136}$, as well as a cohort study from Scotland ${ }^{137}$.

Studies of GWG have also shown conflicting results. A Swedish case-control study ${ }^{104}$ found no association, while two smaller case-control studies, one from Yorkshire ${ }^{138}$ and another from Belgrade ${ }^{139}$, found an increased risk of T1D. Neither of the two studies that found an association adjusted for maternal BMI, and the significant association disappeared in the latter study when adjusting for other significant risk factors found in that study. 
Two cohort studies have been performed on children with an increased genetic risk of T1D. The first, from Norway, found an increased risk of T1D in the offspring for both maternal $\mathrm{BMI} \geq 30$ (compared to $<25, \mathrm{HR} 2.5$ ) and a GWG $\geq 15 \mathrm{~kg}$ (compared to $<15 \mathrm{~kg}, \mathrm{HR} 2.5$ ), independently of maternal diabetes as well as several other confounding factors ${ }^{140}$. The other, from Finland, however, found no association between T1D and maternal BMI before pregnancy or rate of $\mathrm{GWG}^{141}$.

\section{Explanatory hypotheses}

The hypotheses for why maternal BMI and/or GWG could affect the offspring's risk of T1D have to do with the fetal environment, which is hypothesized to affect an individual's later risk of disease. The Developmental Origins of Health and Disease (DOHaD) hypothesis arose from the Barker (or Thrifty Phenotype) hypothesis and is concerned with fetal programming through physiological and/or epigenetic mechanisms ${ }^{122,142}$. The Barker hypothesis states that a nutritional restraint during gestation, leading to a low birthweight, programs the offspring for later disease in adulthood. The reason for this is developmental plasticity, defined as the genotype giving rise to different physiological/morphological states depending on the environment during development, in order to be best adapted for life ${ }^{143}$. DoHaD suggests that in addition to metabolic adaptions, also immune and physiological adaptions to antenatal life modify later health and disease risk, both in childhood and adulthood, as well as in subsequent generations ${ }^{122}$. In the Fuel-Mediated Teratogenesis hypothesis (or the fetal overnutrition pathway) the fetus has, instead of caloric restriction as in the Barker hypothesis, been subjected to fetal over-nutrition and this explains the association between maternal hyperglycemia and excessive growth in the developing fetus ${ }^{131}$.

Glucose can freely cross the placenta, so that elevated b-glucose in the mother leads to elevated glucose levels in the developing fetus. However, insulin cannot cross the placenta, which means that the fetal pancreas responds to the increased glucose levels with increased insulin production ${ }^{131}$. There is a linear association between BMI and b-glucose levels: with increasing BMI the b-glucose increases. This means that in addition to maternal diabetes, maternal overweight and obesity lead to higher circulating glucose levels in the fetus ${ }^{130}$. Studies have suggested that the relationship between maternal glucose levels and the infant's body size is linear ${ }^{131}$. Both maternal and paternal BMI correlates with birthweight, but studies have shown a much stronger association for the mother's BMI compared to the father's, which implies that the intrauterine environment plays a role ${ }^{144}$. 
Insulin is also an important fetal growth hormone ${ }^{131}$ and hyperinsulinemia is adipogenic in late fetal and early infant life. It is hypothesized that fetal hyperinsulinemia increases fat cell number and mass ${ }^{130,131}$ and a study has shown that fetuses of obese mothers, compared to lean mothers, had significantly increased fat mass and body fat percentage, as well as greater fasting umbilical cord insulin and glucose. They were also more insulin-resistant ${ }^{142}$. Animal studies have suggested that fetal hyperinsulinemia in utero may increase the risk of obesity and diabetes by permanent changes in the part of the brain that regulates metabolism and body weight. The endocrine feedback loop (the adipoinsular axis) between the endocrine pancreas, adipose tissue, and the brain, regulates fat storage and hunger through the hormones insulin and leptin. Insulin promotes leptin production and development of fat mass, while leptin reduces energy intake and suppresses insulin secretion. Abnormal functioning of this system may lead to dysregulation of the energy balance regulating system ${ }^{130,131,145}$. In addition, animal studies have also shown that actively secreting pancreatic $\beta$-cells express more antigens on their surfaces ${ }^{146-148}$, which means that overstimulated fetal $\beta$-cells may be more susceptible to autoimmune attacks causing T1D.

Another possibility is that epigenetic changes, by DNA methylation, genomic imprinting and chromatin change resulting in changed gene expression, might occur due to the changed intrauterine environment in diabetic and obese women. The epigenome is particularly susceptible to these alterations during gestation because the DNA synthesis rate is high and DNA methylation patterning is required for normal tissue development ${ }^{131}$. Epigenetic changes could also initiate $\beta$-cell stress and metabolic dysregulation and earlier onset of T1D in the offspring $^{107,149}$.

\section{Hypothesis}

The hypothesis (study II) was that a higher maternal BMI and a greater GWG would increase the risk of T1D in the offspring.

\section{Size for gestational age and birthweight}

In parallel with the increased incidence of T1D there has been a significant increase in pediatric overweight and obesity ${ }^{150}$, as well as an increase in birthweight ${ }^{151}$. A high birthweight has been connected to a higher weight later in childhood ${ }^{133}$ and as adults ${ }^{152}$. Worldwide there is a large difference between the prevalence of children born large for gestational age (LGA) and small for gestational age (SGA). In most countries, there has been an increase in incidence of children born LGA in the last few decades, though in recent years 
there have been reports of a shifting trend. The incidence of children born SGA has instead been stable or decreasing ${ }^{153}$.

The birthweight of a child reflects both the intrauterine environment and genetic factors. A normal birthweight is considered to be between $2,500-3,999 \mathrm{~g}$ and $\geq 4,000 \mathrm{~g}$ is called macrosomia ${ }^{154}$. A birthweight $<1,500 \mathrm{~g}$ is regarded as very low birthweight, and between $1,500 \mathrm{~g}$ and 2,499 $\mathrm{g}$ is low birthweight ${ }^{155}$. Birthweight is known to be affected by several maternal factors such as BMI, GWG ${ }^{124}$, parity, maternal age, nutrition ${ }^{156}$, smoking, and diseases like maternal diabetes and preeclampsia. The birthweight is of course also influenced by the pregnancy length ${ }^{154,157}$.

A pregnancy is counted in completed weeks + days. A pregnancy is considered to have come to full term at 37 weeks +0 days $(37+0)$ up until 41 weeks +6 days $(41+6)$ of gestation. Children born after that are considered post-term $(\geq 42$ weeks $)$ and before that preterm $(<37$ weeks ${ }^{155}$. Children born preterm are sometimes referred to as moderately preterm when born between 32 weeks +0 days $(32+0)$ to 36 weeks +6 days $(36+6)$ and very preterm if born before that $(<32$ weeks).

Many earlier studies investigating whether birthweight is a risk factor for T1D used absolute birthweight, regardless of gestational age at delivery. However, since there is a strong correlation between birthweight and pregnancy length ${ }^{158}$, for example a normal birthweight at term could be excessive if the child is born preterm, it is better to use a classification of birthweight in relation to pregnancy length. Size for gestational age can be divided into appropriate for gestational age (AGA), LGA and SGA. Internationally LGA is often defined as the heaviest $10 \%\left(90^{\text {th }} \text { percentile }\right)^{154}$ and SGA as the lightest $10 \%\left(10^{\text {th }} \text { percentile }\right)^{157}$. In Sweden, SGA is defined as a gender-specific birthweight $\leq 2$ standard deviation (SD) of the mean weight for the gestational length, and LGA as a birthweight $\geq 2$ SD of the mean weight for the gestational length according to the Swedish standard ${ }^{159}$. Not all children born SGA have a fetal growth restriction. Around $20 \%$ will be constitutionally small but healthy with a normal outcome ${ }^{157}$.

\section{Previous studies}

Several studies have investigated birthweight as a risk factor for T1D. Results have been conflicting and different definitions have been used for absolute birthweight and/or birthweight in relation to pregnancy length. A Swedish case-control study, including 4,584 cases, found an increased risk of T1D if the child was born LGA (OR 1.20 [95\% CI 1.02 $1.42])^{160}$ and a cohort study from the UK, including 991 children with T1D, found an 
increased risk of T1D if the child had a birthweight $>4,000 \mathrm{~g}$ vs $<3,000 \mathrm{~g}$ (RR 1.47 [95\% CI $1.16-1.85])^{161}$. A large cohort study from England published in 2017 instead found no association between absolute birthweight and T1D but with T1D and birthweight for gestational age. Compared to children born at 3,000-3,499 g, children born at 3,500-3,999 $\mathrm{g}$ or 4,000-5,499 $\mathrm{g}$, had a higher incidence of T1D and those $<2,500 \mathrm{~g}$ had a lower incidence. Each $500 \mathrm{~g}$ increase in birthweight showed an increased risk of 8\% (HR 1.08 [95\% CI 1.04 $1.12])^{162}$. A meta-analysis from 2010 of 29 observational studies, including 12,807 cases of T1D, found an increased risk of T1D with increased birthweight. A birthweight of 3,500$4,000 \mathrm{~g}$ had a $6 \%$ and $>4,000 \mathrm{~g}$ a $10 \%$ (OR 1.10 [95\% CI $1.04-1.19$ ]) increased risk of T1D, compared to a birthweight of 3,000-3,500 g. This corresponded to a linear increase in T1D risk of $3 \%$ per $500 \mathrm{~g}$ increase in birthweight ${ }^{163}$. Another meta-analysis from 2009 of 12 observational studies showed that a birthweight $>4,000 \mathrm{~g}$, compared to $\leq 4,000 \mathrm{~g}$, was associated with increased risk of T1D with an adjusted OR of 1.43 (95\% CI $1.11-1.85)$. A low birthweight $(<2,500 \mathrm{~g})$ was associated with a non-significant decrease in risk of T1D (OR 0.85 [95\% CI $0.54-1.23]$ ) and each 1,000 g increase in birthweight was associated with a 7\% increase (non-significant) in T1D risk. In all studies included in the meta-analysis, children with T1D also had an increased weight gain during the first year of life compared to control children ${ }^{164}$. An Australian cohort study showed that SGA reduced and LGA increased the risk for children of being diagnosed with $\mathrm{T} 1 \mathrm{D} \geq 3$ years of age. When size for gestational age was treated as an interval variable (SGA, 10-90 ${ }^{\text {th }}$, LGA) it was strongly associated with the onset of T1D. However, birthweight as a continuous variable was not associated with $\mathrm{T}^{1} \mathrm{D}^{105}$. In addition, a case-control study from seven European countries found a decreased risk of T1D in children with a birthweight $<2,500 \mathrm{~g}$, but found no significant effect for SGA $\left(<10^{\text {th }}\right.$ percentile $)^{91}$.

Many studies have also failed to show a correlation between birthweight and/or size for gestational age and later T1D, including a large Swedish cohort study ${ }^{107}$, a case-control study from Washington state $\mathrm{US}^{134}$, as well as a few smaller case-control studies from Denmark ${ }^{92}$, England $^{136}$, Canada ${ }^{106}$, Scotland and Northern Ireland ${ }^{100}$. Furthermore, a Finnish cohort study in children with a high genetic risk of T1D found no increased risk of advanced $\beta$-cell autoimmunity/T1D with birthweight ${ }^{141}$.

In addition to studies of birthweight and risk of T1D, childhood overweight/obesity ${ }^{165}$ and a rapid linear growth in childhood have been shown to increase the risk of T1D ${ }^{166-168}$. Moreover, a large cohort study of German and Austrian children with T1D found a clear 
association between a higher BMI standard deviation score (SDS) and a younger age at onset of $\mathrm{T}^{1} \mathrm{D}^{169}$. A low birthweight $(<2,500 \mathrm{~g})$ has also been shown to correlate with earlier onset of $\mathrm{T}_{1 \mathrm{D}}{ }^{170}$.

\section{Explanatory hypotheses}

There are several hypotheses that could help explain why a child's birthweight or size for gestational age could affect the risk of T1D. In addition to the Barker and DOHaD hypotheses, described above, the Accelerator hypothesis proposes that T1D and T2D are the same, only differentiated by the rate of the $\beta$-cell loss. The accelerators of the process leading to diabetes are: (1) an intrinsically high rate of $\beta$-cell apoptosis (= programmed cell death), (2) insulin resistance and (3) $\beta$-cell autoimmunity, and all three need a high weight gain to cause diabetes. The $\beta$-cell apoptosis is necessary but not sufficient for development of diabetes. The insulin resistance, resulting from physical inactivity and/or weight gain, weakens the glucose control ensuring an increase in b-glucose (glucotoxicity). This accelerates the $\beta$-cell apoptosis, since $\beta$-cells are both metabolically and immunologically upregulated when functionally stressed by rising b-glucose. $\beta$-cell autoimmunity then develops in a small number of genetically predisposed individuals and accelerates the rate of $\beta$-cell loss, ensuring insulin-dependency faster than in T2D. One way the increased apoptosis could induce autoimmunity is by displaying autoantigens ${ }^{171}$. This means that obesity could accelerate the onset of $\mathrm{T}_{1} \mathrm{D}^{172}$.

$\beta$-cell damage may be caused by $\beta$-cell stress, induced by increased insulin secretion, causing cytokine release, neo-antigen formation and increased $\beta$-cell apoptosis. Another possibility is the low-grade inflammation caused by the obesity. This is a consequence of adipose tissue dysfunction and macrophage infiltration. As adipocytes undergo apoptosis, neo-antigens are formed. Macrophages secrete chemokines that recruit lymphocytes and may activate receptors that contribute to the ongoing autoimmune activation ${ }^{173}$. A study in adults with T2D found that the frequency of a specific IA-2 autoantibody increased with BMI in patients with latent autoimmune diabetes in adults (LADA) $)^{174}$.

The Overload hypothesis is very similar to the Accelerator hypothesis. It proposes that in genetically predisposed individuals an overload of the pancreatic $\beta$-cells by an environmental accelerant/trigger, makes them more susceptible to autoimmunity and apoptosis. However, where the Accelerator hypothesis states that weight gain is the necessary accelerant/trigger, the Overload hypothesis is more general, proposing that many different factors can cause 
overload, for example early-life stress, infections, inflammation, or excessive weight gain ${ }^{175}$. Increased birthweight caused by overfeeding in utero may contribute to the overload ${ }^{175}$.

The $\boldsymbol{\beta}$-cell Stress hypothesis is also very similar to the two hypotheses above. It states that any environmental factor that increases the workload on the $\beta$-cell, i.e., that increases insulin resistance or the need for insulin, increases the risk of $\mathrm{T}^{1} \mathrm{D}^{176}$. The actively secreting $\beta$-cells have an increased presentation of insulin and $\mathrm{GAD}^{148}$ and possibly other autoantigens making them more susceptible to an attack by the immune system. Also, a high b-glucose leads to increased oxidative stress in the $\beta$-cells which induces apoptosis and promotes the autoimmune process ${ }^{177}$.

In line with this, the TRIGR study found that an increase in plasma glucose and HbA1c was seen before the development of T1D. They also found that a rise in HbA1c, but not plasma glucose, was associated with the development of a first autoantibody but not multiple autoantibodies ${ }^{89}$. In addition, the Finnish DIPP study in children at high genetic risk of T1D showed that a $10 \%$ increase in HbA1c between samples taken 3-12 months apart, in children positive for $\geq 2$ autoantibodies, increased the risk of clinical onset of T1D after a median time of 1.1 years $^{178}$.

Fetal nutrition determines fetal growth and thereby birthweight ${ }^{179}$, and infants affected by intrauterine growth restriction (IUGR) have been shown to have impaired organ growth ${ }^{180}$. Infants affected by IUGR are born SGA. However, some children born SGA are not IUGR, but rather just genetically small ${ }^{181}$. Infants born SGA often show signs of catch-up growth ${ }^{182}$ and studies have shown that this elevates the risk for obesity later in life ${ }^{180}$. In addition to shown associations with a low birthweight $(<2,500 \mathrm{~g})$ and obesity, studies have also shown a correlation between a high birthweight and later obesity ${ }^{144,180}$.

The association between T1D and birthweight is supported by some animal studies. A study in NOD mice showed that caloric restriction during pregnancy caused a lower birthweight and a reduced risk of diabetes by 24 weeks. The control mice had higher histological evidence of apoptosis and more severe insulitis ${ }^{156}$. A study in BioBreeding (BB) rats, another animal model of T1D, showed that rats developing diabetes consistently had an increased weight from birth compared to rats that did not develop diabetes ${ }^{149}$, and another study found that intermittent feeding and fasting reduced the incidence of diabetes. In addition, infusions of glucose and fatty acids induced apoptosis in rat islets, an effect that was reversed by leptin. A hypothesis put forward is therefore that antenatal undernutrition reduces the incidence of 
diabetes by preventing apoptosis. In humans, a low birthweight has been shown to create defects in the immune system, both in the perinatal period and in adolescence ${ }^{156}$.

Hypothesis

The hypothesis (study III) was that being born either LGA or SGA would affect the risk, independently of maternal BMI and diabetes, of later being diagnosed with T1D.

\section{A connection between genetic and environmental risk factors}

For most of the environmental factors that have been implicated in the etiology of T1D there is conflicting evidence. The discrepancies between study results may be due to different study sizes/power or study designs, different definitions of exposure variables or outcomes, different populations or ages of study participants. Moreover, some have been performed on people with certain genotypes. Some environmental factors may also be important as triggers and others as promoters of the autoimmune process.

It is obvious that T1D is a heterogeneous disease and it is becoming increasingly obvious that there are distinct phenotypes, i.e., that a certain environmental risk factor may be important for individuals with a certain genotype but less important for those with another genotype. In addition, an environmental factor may be important at a certain age but not before or after that age ${ }^{85,183}$. The concept of endotypes, subgroups that may be distinguished from each other, is also being introduced into T1D. In support of this are the facts that individuals with HLADR4-DQ8 more often develop T1D early and with IAA as the first autoantibody, and individuals with HLA-DR3-DQ2 develop T1D a little later and with GADA autoantibodies as the first autoantibody. Moreover, treatment trials have been able to identify subgroups with certain traits who are responders while the whole cohort is not.

In light of this, it is important to try to further elucidate different phenotypes by connecting environmental risk factors to certain genotypes, to sexes, to the development of certain autoantibodies or to age at onset of T1D.

\section{Previous studies}

Birthweight has been investigated in connection to HLA genotypes in the general population. A Swedish study showed that HLA genotypes conferring risk of T1D (HLA-DQ2/8, DQ8/0604 and DQ8/X), as well as a low-risk haplotype (HLA-DQB1*0603), was associated with a high relative birthweight. When compared to the neutral genotype-risk group the result was only significant for DQ2/8 and HLA-DQB1*0603, and the latter more due to a strong protection from a low relative birthweight ${ }^{184}$. A Norwegian study instead found the that the lowest birthweight was among those with DQ2/DQ8 and the highest among 
DQB $1 * 0602 / D Q B 1 * 0602$, which is a low-risk genotype for T1D ${ }^{185}$. A Finnish study also found a link between a high birthweight and HLA (DRB1*13) conferring a low risk of $\mathrm{T}_{1} \mathrm{D}^{186}$. In addition, a cohort study that compared HLA genotypes in Finland, Estonia and Russian Karelia, did not find any direct association of birthweight with HLA DQ2/8, DQ2/x or DQ8/x but an increased birthweight in HLA-DQ8 in combination with HLA-DR2/13$\mathrm{DQ6}^{78}$.

A few studies exploring birthweight and HLA have also been performed on children with T1D. A Finnish study comparing children with T1D and their non-diabetic siblings showed an association between a population-specific HLA haplotype with increased T1D (A2,Cw1,B56,DR4,DQ8) susceptibility and a high birthweight ${ }^{187}$. A German cohort study, on offspring of either a mother or father with T1D, found that mean birthweight in children of mothers with T1D was higher in those with HLA-DR4 than in those without. This difference was not found in children of non-diabetic mothers. They also found a significant interaction between maternal diabetes and child HLA-DR4 status ${ }^{188}$. However, a cohort study (TEDDY) on children at high genetic risk of T1D found no difference in birthweight between the four different genotypes included in the study (DQ2/8, DQ8/8, DQ8/4 and DQ2/2) ${ }^{189}$.

One Swedish cohort study from the south of Sweden with children at high genetic risk for T1D investigated birthweight SDS and found no connection to risk of T1D ${ }^{167}$.

As birthweight is connected to weight later in life $\mathrm{e}^{152}$ it is interesting to note that a study of 2,403 children with newly diagnosed T1D, included in the BDD study, showed that overweight and obesity was more common in children with T1D and low-risk HLA (DQ2/Z, DQX0301/Z, DQX-0602/Z or DQ0603/Z and remaining genotypes) as compared to the general population, whereas no difference was seen in those with a high-risk HLA (DQ2/8 or DQ8/Z). They also found an increasing frequency of DQ2/2 with increasing $\mathrm{BMI}^{73}$.

A few cohort studies, on children at high genetic risk of T1D, have also investigated HLA genotypes and overweight/obesity in childhood. A TEDDY study found no association between early growth and progression to T1D but a weak association between greater weight and height and the development of autoantibodies ${ }^{190}$. Another TEDDY study, of 2-4-year-old children, found that the obesity percentage varied by age, with a decreasing trend among DQ2/8 carriers. They also found that DQ2/2 was independently associated with a significantly higher risk of obesity at the age of four. However, the average BMI at each assessment point was not statistically significant and univariate analysis indicated that the proportion of those 
overweight did not differ significantly with HLA genotype ${ }^{75}$. A TRIGR study found that being overweight at 2-10 years of age was associated with an increased risk of T1D as well as progression from multiple autoantibodies to T1D, but not with the development of autoantibodies ${ }^{165}$. Furthermore, a resent cohort study (TrialNet), found that overweight and obesity was a risk factor for T1D in children $\geq 9$ years of age without HLA-DQ2 or DQ8 ${ }^{191}$. Exactly how and if the HLA genotype could affect birthweight is not known but some other genes have been linked to birthweight ${ }^{192,193}$. In addition to birthweight and size for gestational age, a few of the other environmental risk factors for T1D have been investigated in relation to HLA. A Norwegian case-control study found no significant difference in the relative risk conferred by HLA, INS or PTPN22 by mode of childbirth, maternal age or birthweight, except a possible interaction between PTPN22 and mode of childbirth. However, that study only compared HLA with risk (DQ8/2, DQ8/8, DQ8/X, DQ2/2) vs. all other genotypes ${ }^{194}$. An Italian study found that birth order was inversely associated with HLA genotypes that confer a risk of $\mathrm{T}^{1} \mathrm{D}^{195}$

\section{Hypothesis}

The hypothesis (study IV) was that children who have developed T1D, with an HLA genotype with lower genetic susceptibility, are more often born LGA, with a high birthweight and/or to mothers with a high BMI compared to children who have developed T1D with the highest risk HLA genotype.

A secondary hypothesis was that birthweight, size for gestational age and maternal BMI affect the age at onset of T1D differently, depending on the HLA genotype of the child. 


\section{AIMS}

\section{GENERAL AIM}

The aim of this thesis is to increase the knowledge about factors during pregnancy and the perinatal period that could increase or decrease the risk of T1D among children and adolescents. Hopefully, it can add knowledge regarding the puzzling etiology of T1D and increase the understanding of the increased incidence of T1D seen in the last few decades.

\section{SPECIFIC AIMS}

\section{Study 1}

To investigate whether there is an association between CS and the risk of T1D onset in childhood.

\section{Study II}

To explore maternal characteristics by focusing on the possible effect of maternal BMI and GWG on the subsequent risk of T1D in the offspring.

\section{Study III}

To investigate perinatal risk factors of the child by investigating whether size for gestational age affects the future risk and the age at onset of T1D and to determine whether there is a sex difference.

\section{Study IV}

To examine if maternal BMI, size for gestational age or birthweight differ with HLA genotype in children diagnosed with T1D. In addition, to investigate if these factors also impact age at onset of T1D in children differently, depending on the child's HLA genotype. 


\section{OVERVIEW}

A brief summary of the methodology used in the four sub-studies that are the basis for this thesis is presented in Table 2 .

Table 2 Summary of methodology

\begin{tabular}{|c|c|c|c|c|}
\hline Study & I & II & III & IV \\
\hline Type of study & Observational & Observational & Observational & Observational \\
\hline Design & $\begin{array}{l}\text { Population-based } \\
\text { case-control } \\
\text { study }\end{array}$ & $\begin{array}{l}\text { Population-based } \\
\text { case-control study }\end{array}$ & $\begin{array}{l}\text { Population-based } \\
\text { case-control study }\end{array}$ & $\begin{array}{l}\text { Population-based } \\
\text { cohort study }\end{array}$ \\
\hline Data Source & $\begin{array}{l}\text { SWEDIABKIDS, } \\
\text { MBR }\end{array}$ & $\begin{array}{l}\text { SWEDIABKIDS, } \\
\text { MBR }\end{array}$ & $\begin{array}{l}\text { SWEDIABKIDS, } \\
\text { MBR }\end{array}$ & $\begin{array}{l}\text { SWEDIABKIDS, } \\
\text { MBR, BDD }\end{array}$ \\
\hline $\begin{array}{l}\text { Data collection } \\
\text { period }\end{array}$ & $\begin{array}{l}\text { Jan } 2000-\text { Oct } \\
2012\end{array}$ & $\begin{array}{l}\text { Jan } 2000-\text { Oct } \\
2012\end{array}$ & $\begin{array}{l}\text { Jan } 2000-\text { Oct } \\
2012\end{array}$ & $\begin{array}{l}\text { May } 2005 \text { - Oct } \\
2012\end{array}$ \\
\hline Subjects & $\begin{array}{l}9,376 \text { children } \\
\text { with T1D and } \\
37,504 \text { age- and } \\
\text { sex-matched } \\
\text { control children. }\end{array}$ & $\begin{array}{l}3,231 \text { children } \\
\text { with T1D and } \\
12,948 \text { control } \\
\text { children }\end{array}$ & $\begin{array}{l}9,278 \text { children } \\
\text { with } \mathrm{T} 1 \mathrm{D} \text { and } \\
37,050 \text { age- and } \\
\text { sex-matched } \\
\text { control children. }\end{array}$ & $\begin{array}{l}4,533 \text { children } \\
\text { with T1D. }\end{array}$ \\
\hline Exposures & Cesarean section & $\begin{array}{l}\text { Maternal BMI } \\
\text { and GWG. }\end{array}$ & $\begin{array}{l}\text { Size for } \\
\text { gestational age }\end{array}$ & $\begin{array}{l}\text { Genotype, } \\
\text { maternal BMI, } \\
\text { birthweight, } \\
\text { size for gestational } \\
\text { age }\end{array}$ \\
\hline $\begin{array}{l}\text { Outcome } \\
\text { measures }\end{array}$ & T1D & T1D & T1D & $\begin{array}{l}\text { Age at onset of } \\
\text { T1D, birthweight, } \\
\text { size for gestational } \\
\text { age }\end{array}$ \\
\hline Statistics & $\begin{array}{l}\text { Pearson's } \chi^{2} \text { test, } \\
\text { student's t test, } \\
\text { multiple logistic } \\
\text { regression }\end{array}$ & $\begin{array}{l}\text { Pearson's } \chi 2 \text { test, } \\
\text { multiple logistic } \\
\text { regression }\end{array}$ & $\begin{array}{l}\text { Pearson's } \chi 2 \text { test, } \\
\text { multiple logistic } \\
\text { regression }\end{array}$ & $\begin{array}{l}\text { Pearson's } \chi 2 \text { test, } \\
\text { ANOVA, } \\
\text { ANCOVA, } \\
\text { multinomial } \\
\text { logistic regression }\end{array}$ \\
\hline
\end{tabular}

SWEDIABKIDS $=$ Swedish Pediatric Diabetes Quality Registry, MBR=Medical birth registry, BDD= Better Diabetes Diagnosis study, $\mathrm{T} 1 \mathrm{D}=$ type 1 diabetes, $\mathrm{ANOVA}=$ analysis of variance, $\mathrm{ANCOVA}=$ analysis of covariance.

\section{DATA SOURCES}

\section{$\underline{\text { Registers }}$}

\section{Swedish Medical Birth Register (MBR)}

This national register, established in 1973, is held and administered by the National Board of Health and Welfare and contains information on 96.1-99.5\% of all pregnancies in Sweden. 
Missing cases are due to the hospitals' error in reporting. The register has been validated several times (published in 1976, 1988, and 2001) ${ }^{196}$.

The register is based on standardized medical charts from antenatal, obstetric, and neonatal care and contains information on a large number of factors related to pregnancy, childbirth and the perinatal period. For example, there is information on reproductive history, lifestyle habits like smoking, anthropometric data on mother and child, mode of childbirth, pregnancy length, Apgar score and complications during pregnancy and childbirth. Complications as well as the woman's potentially pre-existing diagnoses are classified according to the Swedish version of the International Statistical Classifications of Diseases and Related Health Problems (ICD) system, the $8^{\text {th }}$ edition (ICD-8) was used through 1986, between 1987 and 1996 the ICD-9 was used, and from 1997 onwards the ICD-10. All information in the register is prospectively collected by the health care professionals responsible for patient care and from the woman's first antenatal visit (usually between gestational weeks 8 to 12). The main structure of the register has been constant since 1973, and the form of reporting has been the same since 1982. Smaller changes, mainly adding new variables, were made to the register in 1990, 1994 and 1998. In 1997, the MBR started to report the mothers' different types of diabetes, i.e., O24.0 pre-existing T1D, O24.1 pre-existing T2D and O24.4 GDM. Before that the diagnosis of diabetes was not always further specified ${ }^{196}$.

\section{Swedish Pediatric Diabetes Quality Register (SWEDIABKIDS)}

This national quality register (http://www.ndr.nu/\#/omswediabkids) was stepwise and randomly introduced in Sweden during 2000-2007 and during this period data was registered locally by doctors and/or nurses in a specially designed program for childhood diabetes. Since 2008, all pediatric clinics in Sweden (initially 43, later 42 due to incorporation of one into another) have participated and the register is web-based and available to all pediatric centers in Sweden. Since all children and adolescents diagnosed with diabetes are treated at one of the pediatric clinics, the register includes data on approximately $99 \%$ of children and adolescents with diabetes in Sweden. The diagnosis and classification of diabetes is carried out according to the recommendations by the American Diabetes Association ${ }^{197}$, and initially it was based on clinical symptoms and signs. Since 2005 onwards, the diagnosis has been strengthened by information on autoantibodies, HLA genotype and C-peptide ${ }^{198}$. All newly diagnosed children and caregivers are informed and give oral consent before being registered, and from the time of diagnosis all data are prospectively reported. On 31 December 2019, the register included data from 20966 patients (unpublished data, K. Åkesson, one of the keepers of the register). 
SWEDIABKIDS is financially supported by the Association of Local Authorities and Regions, which represents the professional, governmental and employer-related interests of Sweden's municipalities, county councils and regions (http://skr.se/english).

\section{Better Diabetes Diagnosis (BDD) study}

The BDD study is an ongoing national cohort study, in which all children (0-18 years) with newly diagnosed diabetes are invited to participate (since January $2011>95 \%$ included). All children and their caregivers are informed and asked to give consent before inclusion. The primary aim of the BDD study is to enable a more precise classification and diagnosis of diabetes, thereby improving treatment to every patient. Secondary aims include to identify risk factors for diabetes-related co-morbidities, to investigate genetic factors associated with T2D, to explore how ethnicity and country of origin interact with environmental factors for T1D risk and to investigate predictors for autoimmune comorbidity ${ }^{21}$.

The BDD study includes analysis of HLA genotypes, C-peptide, and autoantibodies. All blood samples are taken at the first hospital visit after diabetes onset, in most cases before insulin has been given. Between 2005 and 2010, BDD was performed within a research setting (BDD1), and all children were tested for autoantibodies against GAD65, IA, IA-2 and ZnT8. Since 2011, BDD has been partly used in the clinical routine in Sweden (BDD2) and children are now first tested for GADA and IA-2A. If the patient is negative for both autoantibodies the sample is further analyzed for the other autoantibodies ${ }^{21}$.

\section{STUDY POPULATIONS AND STUDY DESIGNS}

\section{Studies I - III}

Studies I - III are case-control studies and all used the same original study population with some modifications (Figure 2).

The study population consisted of children and adolescents (aged $0-18 / 19$ years) diagnosed with T1D between January 2000 and October 2012 and registered in the SWEDIABKIDS (n =9,376). All children with diabetes were matched with four control children from the MBR with the same year and day of birth, same sex, and born in the same region of Sweden ( $\mathrm{n}=$ 37,504). The children were born between 1982 and 2011 (91\% between 1990 and 2011), $25,860(55.2 \%)$ were boys and 21,020 (44.8\%) were girls. The age at diagnosis varied between 0 to 19 years of age (four children were 0 years and two 19 years). In study I the 
entire study population was used but in study III twins were excluded ( $\mathrm{n}=552 ; 454$ control children and 98 children with T1D).

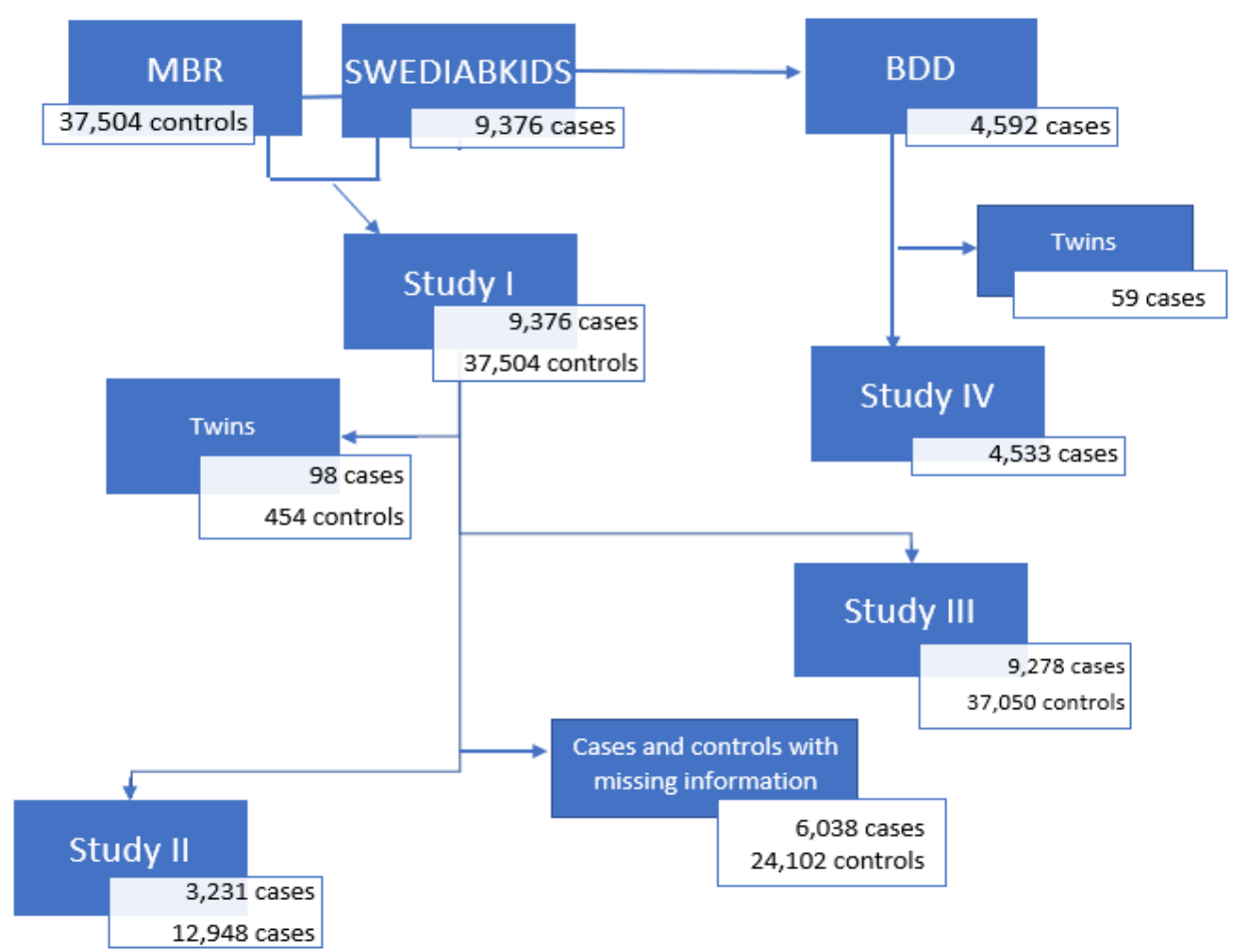

Figure 2 Study populations

In study II, we included children for whom data on their mother's BMI in early pregnancy and GWG were available. In total, there were 16,179 individuals: 3,231 children with T1D and 12,948 control children. The children were born between 1982 and 2011; the majority were born between 1990 and 2011 (93.2\%). Boys comprised 55.5\%, girls 44.5\%.

For the total study population ( $n=46,880,9,376$ cases $+37,504$ controls) the mothers' unique personal identification number was used to retrieve information from the MBR regarding the woman's height and weight in early pregnancy as well as at childbirth, parity, smoking habits, gestational week at childbirth and mode of childbirth. Information was also collected about maternal diabetes corresponding to the diagnostic code O24 in ICD-10 ${ }^{199}$, as well as information on the child's Apgar score, weight and height at birth. For study I, there are missing data in the MBR on maternal BMI in early pregnancy $(n=12,021,25.6 \%)$, duration of pregnancy $(n=62,0.1 \%)$, Apgar score $(n=7,723,16.5 \%)$, smoking in early pregnancy $(n=2,703,5.8 \%)$, parity $(n=3,0.0 \%)$ and birthweight $(n=136,0.3 \%)$. For study II, there are 
missing data in the MBR for 416 women (2.6\%) on smoking during pregnancy. For study III, there are missing data on maternal BMI in early pregnancy $(n=11,927,25.7 \%)$, weight gain during pregnancy $(n=30,288,65.4 \%)$, smoking during pregnancy $(n=2,263,4.9 \%)$, duration of pregnancy $(n=60,0.1 \%)$, parity $(n=3,0.0 \%)$ and birthweight $(n=132,0.3 \%)$.

\section{Study IV}

Study IV is a cohort study, and the study population consisted of the same children with T1D as in paper I, but who also participated in the BDD study (Figure 2). In total there were 4,592 children: however, multiples were excluded ( $n=59)$. Among the remaining 4,533 children, 3,535 were part of BDD1 and 998 of BDD2. The children were born between 1986 and 2011 (92.4\% between 1991 and 2007) and were diagnosed with T1D between 2005 and 2012. The sex distribution was $55.1 \%(n=2,497)$ boys and $44.9 \%(n=2,036)$ girls.

Information from the MBR was collected as described for studies I-III. For this cohort there were missing data in the MBR on maternal BMI in early pregnancy $(n=830,18.3 \%)$, pregnancy length $(n=2,0.0 \%)$, parity $(n=1,0.0 \%)$, maternal smoking habits $(n=200,4.4 \%)$ and the child's birthweight $(\mathrm{n}=12,0.3 \%)$. In BDD there were missing data on genotype for $1.2 \%(\mathrm{n}=53)$.

\section{Definition of variables}

For definition of exposure, outcome and confounders for studies I-IV see Figures 3-7 below. Information on all variables was collected from the MBR except for the HLA genotype where information was collected from the BDD study.

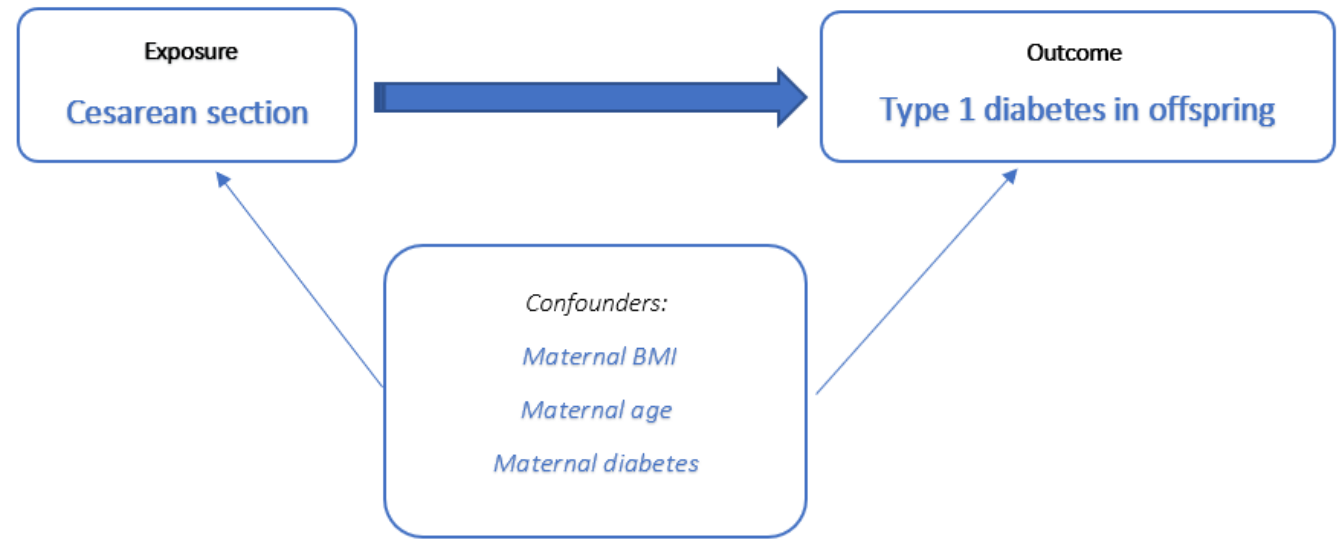

Figure 3 Exposure, outcome and confounders in study I 


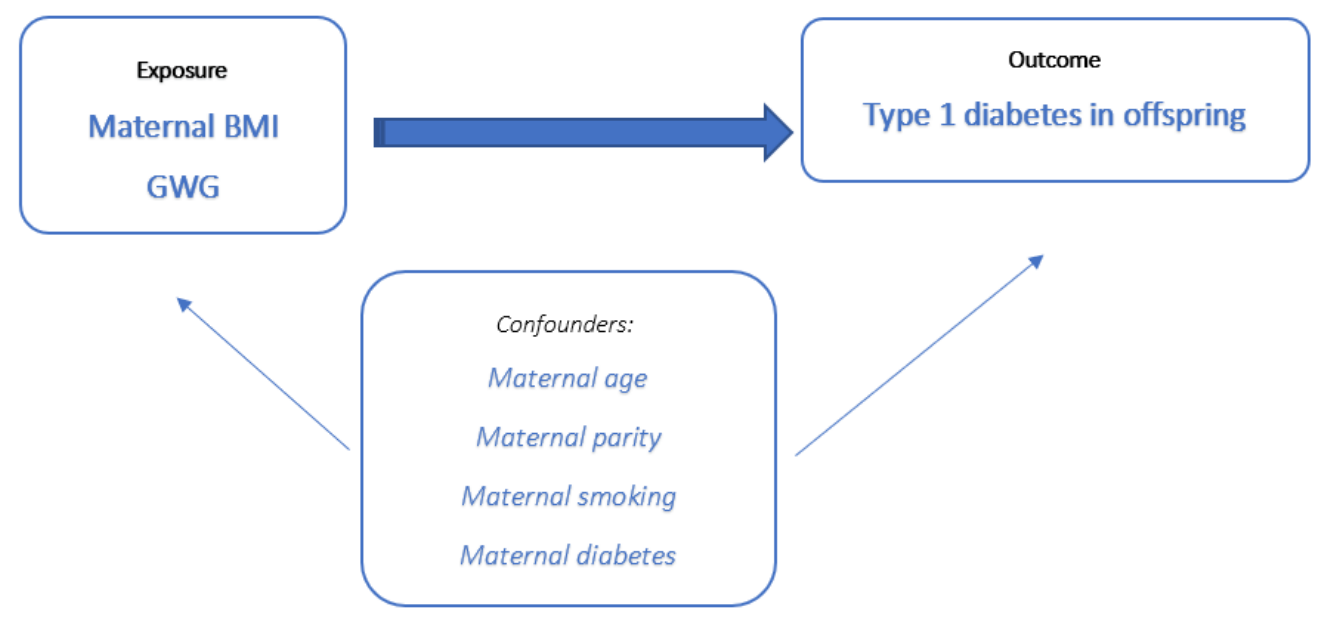

Figure 4 Exposure, outcome and confounders in study II

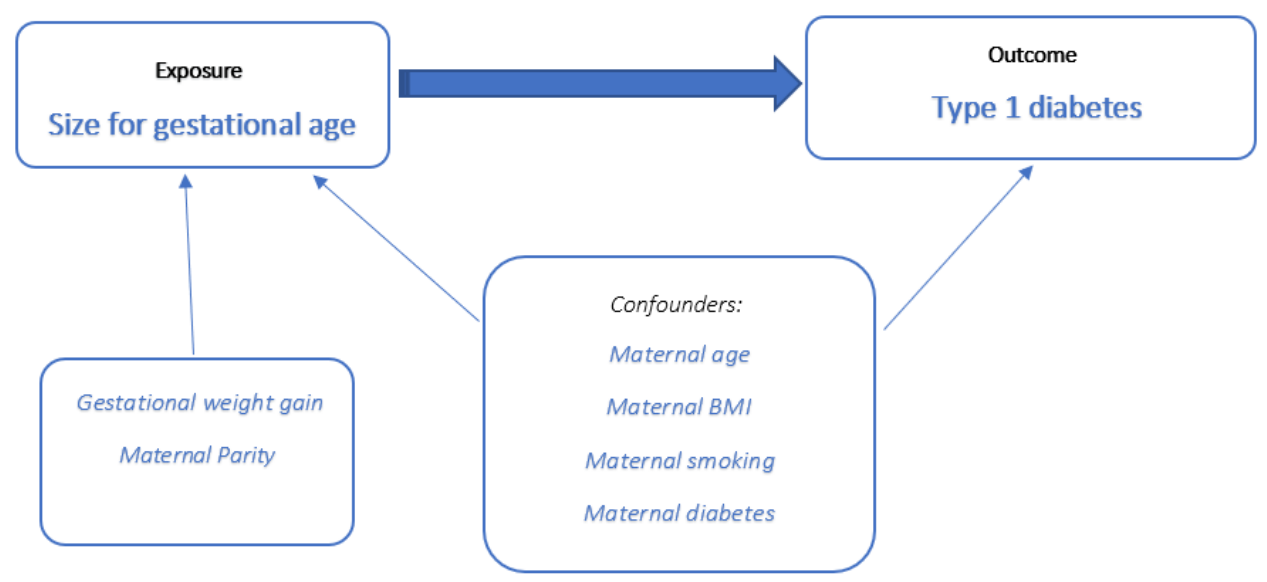

Figure 5 Exposure, outcome and confounders in study III 


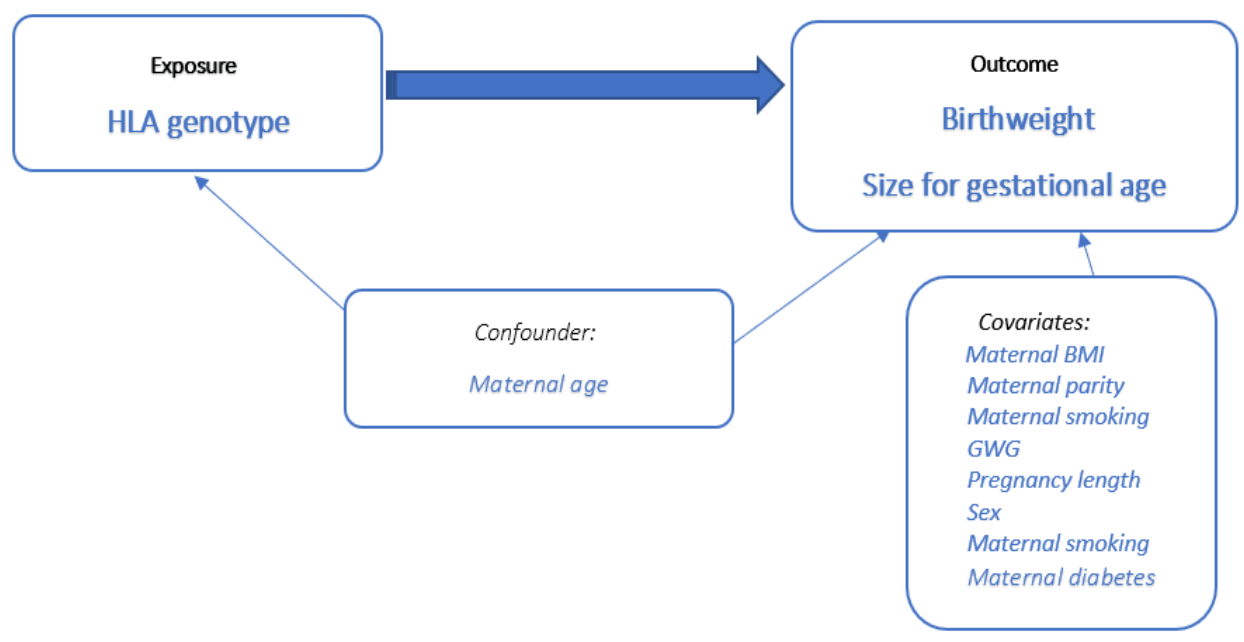

Figure 6 Exposure, outcome and confounders in study IV

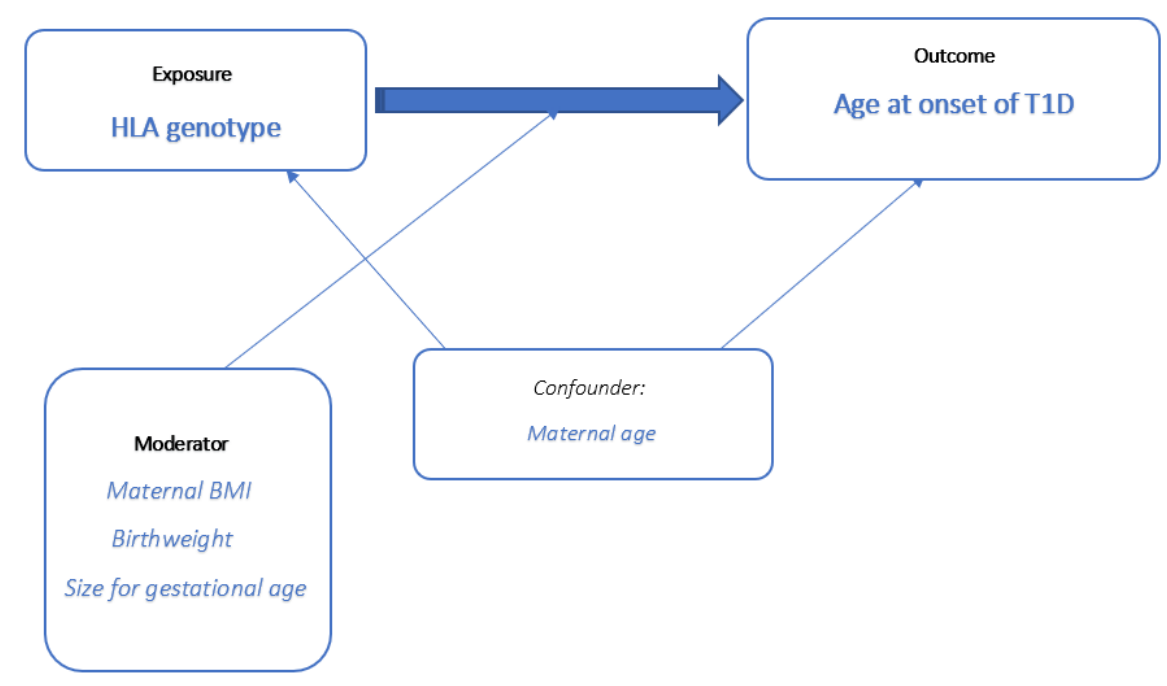

Figure 7 Exposure, outcome and confounders of the secondary hypothesis in study IV

Mode of delivery or childbirth: Vaginally or CS. CS was also sometimes divided into acute CS and planned CS. This variable was only used in study I.

Maternal age: In study I the variable was divided into six groups (age <20; 20-25; 26-30; 31$35 ; 36-40$ and $>40$ years) but was also used as a continuous variable. In studies II - IV 
maternal age was instead used as a categorial variable with two groups (13-29 years and $\geq 30$ years).

Maternal diabetes: This variable was a composite of all types of diabetes, i.e., T1D, T2D and GDM and was used in all papers. Furthermore, in studies I and II, subgroup analysis of children born after 1997, when the MBR started to report the different forms of diabetes, was done.

Maternal BMI in early pregnancy: This variable is referred to as Maternal BMI and was used in all studies. In study I, and partly in study IV, maternal BMI was used as a continuous variable. In studies I-IV BMI was also categorized into BMI groups according to the world health organization (WHO) classification of BMI cut-off values ${ }^{200}$. In studies II and III, women were categorized into four groups: underweight $\left(<18.5 \mathrm{~kg} / \mathrm{m}^{2}\right)$, normal weight (BMI $18.5-24.9 \mathrm{~kg} / \mathrm{m}^{2}$ ), overweight (BMI $25.0-29.9 \mathrm{~kg} / \mathrm{m}^{2}$ ) and obese (BMI $\left.\geq 30.0 \mathrm{~kg} / \mathrm{m}^{2}\right)$. In study IV an additional group was created for those with morbid obesity (BMI $\geq 35.0 \mathrm{~kg} / \mathrm{m}^{2}$ ). Also, in study IV, the grouping was sometimes simplified into two groups with a cut-off at BMI 25 . This was done because only $4 \%(n=87)$ of women were underweight and $10.8 \%(n=396)$ were obese.

In paper III, a new variable containing maternal BMI and maternal diabetes was created. This variable had four categories (maternal BMI $<25 \mathrm{~kg} / \mathrm{m}^{2}$ and no maternal diabetes, maternal $\mathrm{BMI} \geq 25 \mathrm{~kg} / \mathrm{m}^{2}$ and no maternal diabetes, maternal BMI $<25 \mathrm{~kg} / \mathrm{m}^{2}$ and maternal diabetes of any kind, maternal $\mathrm{BMI} \geq 25 \mathrm{~kg} / \mathrm{m}^{2}$ and maternal diabetes of any kind).

GWG: Each BMI class has a recommended GWG according to the 2009 guidelines of the IOM and the US National Research Council ${ }^{126}$. For underweight women it is $12.5-18.0 \mathrm{~kg}$, for normal weight women $11.5-16.0 \mathrm{~kg}$, for overweight women $7.0-11.5 \mathrm{~kg}$ and for obese women 5.0-9.0 kg. Weight gain within these recommendations is defined as adequate, below as inadequate, and above as excessive. This variable was used in studies II and III.

Maternal smoking during pregnancy: Referred to as maternal smoking. A composite of women who smoked in either, or both early and late pregnancy. This variable was used in studies II - IV.

Parity: Parity was categorized as primiparous (first time mother) and multiparous. This variable was used in studies II - IV.

Gestational age at birth/pregnancy length: Children were categorized into four groups according to age at birth. In studies II and III the variable had four groups: very preterm $(<32$ 
weeks of gestation), moderately preterm ( $32+0$ through $36+6$ weeks), term $(37+0$ through $41+6$ weeks) and post-term ( $\geq 42$ weeks). However, in study IV only $24(0.5 \%)$ children were delivered $<32$ weeks and were therefore included with the moderately preterm. This created a variable with three groups: preterm ( $<37$ weeks), term $(37+0$ through $41+6$ weeks) and postterm $(\geq 42+0$ weeks $)$.

Birthweight: In study I, and partly in study IV, birthweight was used as a continuous variable. In study III, birthweight was categorized into four groups: very low birthweight $(<1,500 \mathrm{~g})$, low birthweight (1,500-2,499 g), normal birthweight $(2,500-3,999 \mathrm{~g})$ and macrosomia $(\geq 4,000$ g). In study IV, only $15(0.3 \%)$ children had a very low birthweight and these were instead included in the low birthweight category $(<2,500 \mathrm{~g})$.

Size for gestational age: SGA was defined as a gender-specific birthweight $\leq 2$ SD of the mean weight for the gestational length. LGA was similarly defined as a birthweight $\geq 2$ SD of the mean weight for the gestational length according to the Swedish standard ${ }^{159}$. Children who were neither SGA, nor LGA were considered as AGA. Children with missing values on either birthweight or gestational age in study III (1,237 children [0,3\%]) and in study IV (14 children $[0,3 \%])$, were assumed to be AGA.

Age at onset of T1D: This variable is given as a continuous variable and used as such in studies I and IV. In studies II-IV, the variable was categorized into four groups: 0-4 years, 5-9 years, 10-14 years and 15-18/19 years of age.

HLA genotype of the child with T1D. The children with T1D were divided into four groups according to their HLA genotype:

(1) HLA-DQ2/8

(2) HLA-DQ8/X (X is not 2)

(3) HLA-DQ2/X (X is not 8)

(4) HLA-DQX/X ( $\mathrm{X}$ is neither 2 nor 8$)$.

This variable was only used in study IV.

\section{LABORATORY METHODS}

\section{HLA genotyping}

The HLA genotyping is done slightly different in BDD1 and BDD2. In BDD 1 the HLA genotype is determined by polymerase chain reaction $(\mathrm{PCR})^{21}$. In brief, dried blood spots 
were used to obtain $3 \mathrm{~mm}$ punches for PCR amplification of DQA1 and DQB1 alleles, as previously described ${ }^{201}$. Single-stranded DNA was hybridized with two sets of probes and samples positive for DQB $1 * 02$ were further analyzed for DQA $1 * 02: 01$ and *05:01 alleles to distinguish subjects with DR7 from those with DR3. HLA-DQA1 typing was performed with the same technique as for DQB1 typing with some modifications, as previously described ${ }^{201}$. In BDD2 DNA was instead extracted from EDTA-blood and the HLA genotyping was obtained by PCR sequence-specific primers (PCR-SSP) and has previously been described ${ }^{21}$. In short, the PCR-SSP separate different DRB1, DQA1 and DQB1-alleles. If interpretations of the results were complicated, the PCR-SSP was also used to identify the specific DRB1 alleles to verify risk alleles, even though they are linked with known haplotypes together with DQ8 and DQ2 due to linkage disequilibrium. Information from the IMGT/HLA database, version 3.12.0 (http://www.ebi.ac.uk/imgt/hla/index.html) was used to obtain the DNA sequence for the different primers to detect HLA alleles.

\section{STATISTICS}

\section{Descriptive statistics}

Continuous data were presented as mean and SD or mean and 95\% CIs. Categorical variables were presented as numbers (n) and percentages (\%).

\section{Inferential statistics}

A p-value of $<0.05$ (two-sided) was considered statistically significant in all four studies.

\section{Continuous data}

The Student's T test was used to assess differences between mode of childbirth and continuous, normally distributed, variables such as maternal age when giving birth, BMI in early pregnancy and birthweight, as well as Apgar score at five and ten minutes.

Analysis of variance (ANOVA) was used to explore difference in mean birthweight and maternal BMI between the HLA genotype groups, as well as to assess the mean age at onset of T1D within each HLA genotype group depending on maternal BMI, birthweight, and size for gestational age.

\section{Categorical data}

The Pearson's chi-square $\left(\chi^{2}\right)$ test was used for categorical variables to analyze the difference in the proportion of children who developed T1D and the exposure variables of interest. The 
$\chi^{2}$ test was also used to assess the association between age at onset of T1D in relation to maternal BMI, size for gestational age and birthweight, as well as to analyze the distribution of maternal and infant characteristics between the HLA genotype groups.

\section{Logistic regression}

Logistic regression is a statistical method used to investigate if there is an association between an outcome (the dependent variable) and one or several independent variables (exposures). When one independent variable is used it is called simple logistic regression and the OR presented is called crude (unadjusted). When two or more independent variables are used it is called multiple logistic regression, and the OR presented is called adjusted. The latter is performed to account for confounding.

The dependent variable must be binary (yes/no), for example, the child has T1D or not. The independent variables can be continuous or ordinal (both discrete [on a scale] or nominal [without a scale]). The method is more reliable the larger the sample size is. The OR presented is the ratio between the odds that the case was exposed against the odds that the control was exposed.

Single and multiple logistic regression was used to assess the outcome in studies I-III. The risk estimates were presented as ORs with 95\% CIs and both crude and adjusted ORs were presented. All regression models were run as complete case analyses.

The dependent variable was T1D in the child, and independent variables were the environmental factors of interest as well as the confounders considered in each study (see figure 3-5). In study I a separate model was performed where the dependent variable was birth by CS, and maternal age when giving birth, maternal BMI in early pregnancy, sex of the child and age at onset of T1D were all included as independent variables.

\section{Multinomial logistic regression}

This method was used when the dependent variable had more than two categories (study IV). Also here, all analyses were run as complete case analyses. The dependent variable was either birthweight or size for gestational age and the independent variable was HLA genotype. The confounder 'maternal age' was also included as an independent variable.

Also, stratified analysis according to HLA genotype groups was performed. Age at onset of T1D was the dependent variable and independent variables were maternal BMI, birthweight, and size for gestational age. The independent variables were modeled separately and were 
adjusted for the confounder 'maternal age'. Additive interaction effects between the independent variables and maternal age were evaluated, but since none of these were found to be significant, the final models did not include interaction effects.

\section{Analysis of covariance (ANCOVA)}

ANCOVA is a combination of ANOVA and linear regression and is used to control for confounding. It was used when investigating mean birthweight between HLA genotype groups to account for maternal age.

\section{Statistical software}

All statistical analysis was performed using IBM SPSS (IBM, Armonk, NY, USA), but different versions: for study I, version 22, study II, version 23, study III, version 25 and study IV, version 27. 


\section{ETHICAL APPROVAL AND CONSIDERATIONS}

The studies in this thesis were approved by the regional ethics review board in Linköping (No 2011/381-31) prior to any data retrieval. In addition, the BDD study was approved by the Ethics Committee at the Karolinska Institute (No 04-826/1, with amendments 2006/108-32/1, 2007/1383-32/1, 2009/1684/32, 2011/1069-32, and 2016/1950-32).

There are several important ethical aspects to consider when conducting research. There must be a valid balance between the risk of harm and the potential benefit of the research. T1D is a difficult disease to study since the organ of interest is not easily accessible and the disease process starts years before the clinical onset. Knowledge of environmental risk factors and how they may pertain to genetic risk is lacking. To conduct a randomized controlled trial (RCT) on this subject is not possible, and though prospective cohort studies present the best methodology, using readily available information from registers to complement these is justifiable. There is no potential harm to included individuals and the results from studies can increase knowledge and bring about new hypotheses for future research.

The BDD study required and still requires informed consent. SWEDIABKIDS is a national longitudinal quality register, and all children and caregivers are informed and give consent before inclusion. The child/adolescent is longitudinally registered at the outpatient clinic. As described, the MBR is a national register that contains information about the pregnancy, delivery and antenatal health of the child, and inclusion does not require personal consent. In Sweden, register-based research with information from large population registers does not require personal consent, as data is anonymized and results are given on a group level. This makes the research unlikely to cause any negative consequences for the included individuals. The exception to this is when studying a very rare disorder, which in the present studies is not likely to be a problem. At the time the data for this thesis was obtained, the usage of data from registers was regulated in the "Personal data act" of 1998. The legislation today is instead the "General data protection regulation" (GDPR) and the Swedish law that supplements the GDPR, the "Data Protection Act (2018:218). Before data can be accessed, permission is given by the Swedish Ethical Review Authority (since 2019: before that, it was given by the regional ethical review boards) and even after that the agencies can deny access if usage is not in line with the legislation.

After ethical approval, an application to access data from MBR, SWEDIABKIDS and BDD was made. Data from the MBR was retrieved unidentified, but data from SWEDIABKIDS 
and BDD was obtained using the individuals' unique identification numbers. However, after retrieval, data was anonymized and all results have been given on group level, again making identification and negative consequences for the individual highly unlikely.

In addition, when using a large body of material, like the one in this thesis, one must always remember that statistical significance does not necessarily mean clinical relevance, and results must be interpreted with caution. 


\section{RESULTS}

In the result section each environmental risk factor investigated in this thesis is discussed separately.

\section{MODE OF CHILDBIRTH}

In total, $13.5 \%$ of the 46,880 children were born by CS, as were $14.7 \%$ of children who later developed T1D and $13.3 \%$ of control children $(\mathrm{p}<0.001)$. Furthermore, among mothers of children who developed T1D, $4.8 \%(n=453)$ gave birth by acute CS, compared to $3.3 \%(n=$ $1,254)$ of the mothers of control children $(\mathrm{p}<0.001)$, whereas there was no difference in planned CS (9.9\% each).

Compared with women who gave birth vaginally, women who gave birth by CS were older (30.5 years \pm 5.2 vs 28.8 years $\pm 5.0, \mathrm{p}<0.001)$, had a higher BMI $\left(24.9 \mathrm{~kg} / \mathrm{m}^{2} \pm 4.6\right.$ vs 23.7 $\left.\mathrm{kg} / \mathrm{m}^{2} \pm 4.0, \mathrm{p}<0.001\right)$ and were more likely to have diabetes $(7.5 \%[\mathrm{n}=476$,$] vs 0.3 \%$ $[\mathrm{n}=128], \mathrm{p}<0.001)$.

Women with diabetes more often gave birth by CS than women without diabetes $(78.8 \%$ $(n=476]$ vs $12.7 \%$ [ $n=5,873], p<0.001)$. Of the 604 women with diabetes, $20.9 \%(n=126)$ gave birth vaginally, $28.8 \%(n=174)$ by acute CS, and $50.3 \%(n=304)$ by elective CS. If the women had T1D ( $n=213), 97.7 \%$ gave birth by CS $(n=208)$, of which $62 \%(n=129)$ had a planned CS. Among women without diabetes, the corresponding figures were $87.3 \%$ $(n=40,403)$ for vaginal birth, 9.7\% $(n=4,470)$ for acute CS and 3.0\% $(n=1,403)$ for planned CS (Figure 8).

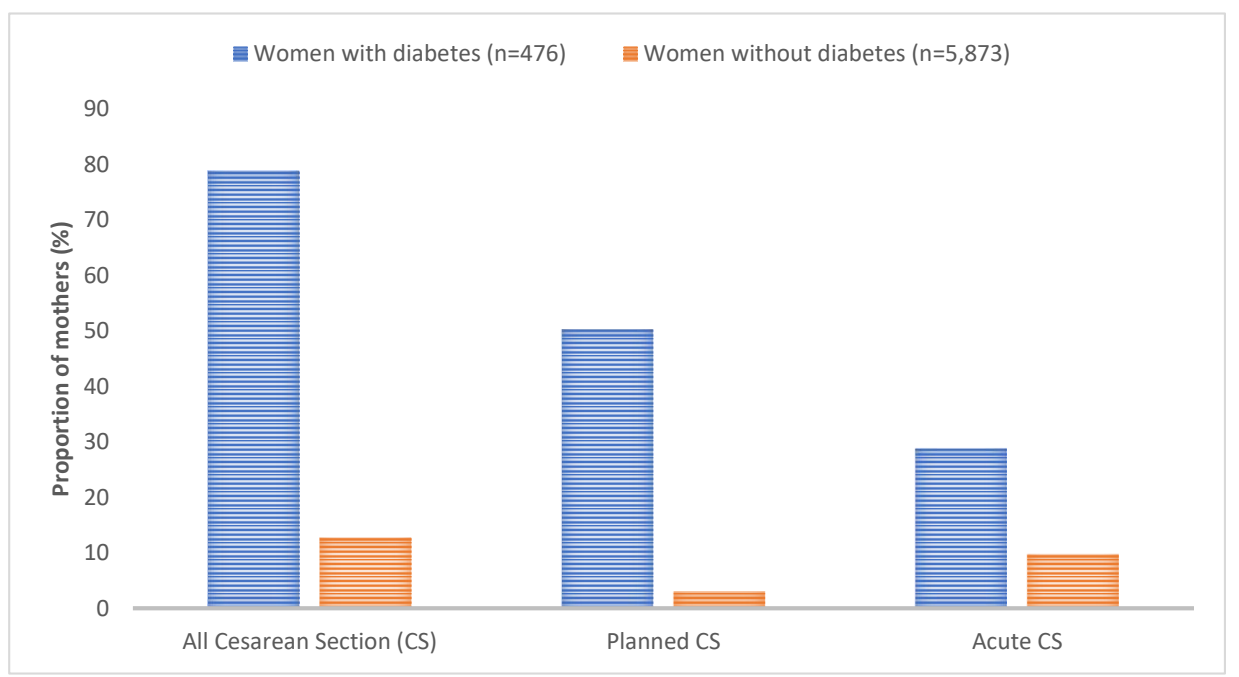

Figure 8 A significantly higher proportion of mothers with diabetes gave birth by CS than mothers without diabetes $(\mathrm{p}<0.001)$. 
Mothers without diabetes had the same proportion of children who later developed T1D regardless of mode of childbirth (19.7\% vaginal birth vs $19.6 \%$ birth by CS). Furthermore, among children born to mothers with diabetes $(n=604)$, there was no statistically significant difference in mode of childbirth between index and control children $(\mathrm{p}=0.113)$.

In the logistic regression model, the crude OR for developing T1D if the child had been born by CS was 1.12 (95\% CI $1.06-1.20)$. However, when adjusting for maternal diabetes the association became non-significant with OR 1.02 (95\% CI $0.94-1.10)$. Including maternal T1D or maternal age did not change this result, and there was no significant interaction between maternal diabetes and CS (Table 3). Moreover, the crude OR for a child with T1D to have been born by CS if the mother did not have diabetes was 1.00 (95\% CI $0.93-1.07$ ).

Table 3 OR of developing T1D depending on mode of childbirth and maternal characteristics.

Crude OR (95\% CI)

Adjusted OR (95\% CI)

\begin{tabular}{c|c|c|c}
\hline Cesarean section & $1.12(1.06-1.20)$ & $1.02(0.94-1.10)$ & $0.97(0.88-1.07)$ \\
Maternal diabetes & $3.44(2.92-4.04)$ & $3.41(2.82-4.12)$ & - \\
Maternal BMI & $1.02 *(1.01-1.02)$ & $1.02(1.01-1.02)$ & $1.01(1.01-1.02)$ \\
Maternal T1D & $7.90(5.94-10.50)$ & - & $7.54(5.50-10.40)$ \\
Maternal age & $1.00(0.99-1.01)$ & $1.00(0.99-1.01)$ & $1.00(0.99-1.01)$ \\
\hline
\end{tabular}

Adjusted OR includes cesarean section, maternal diabetes and maternal age or CS, maternal T1D and maternal age. The model including T1D includes in total 21,555 mothers/children. Otherwise, 46,880 mothers/children. BMI and age are continuous variables.

\section{MATERNAL BMI and GWG}

As a continuous variable, maternal BMI had a small influence on the risk of T1D in the child with an adjusted OR of 1.02 (95\% CI 1.01-1.02) (Table 3). This means that for each additional step increase in maternal BMI the risk of T1D in the offspring increased by $2 \%$. Unfortunately, it was only possible to calculate GWG for $34.5 \%$ of mothers in our study population, primarily due to missing information on weight at childbirth, and study II was therefore performed on a smaller part of the material. A missing case analysis revealed no difference between those where GWG was available and those where it was missing for the variables maternal diabetes or Apgar score of the child. For the following variables there was a significant difference: maternal age, parity, maternal smoking, maternal BMI and pregnancy length. Among subjects with available data there were more with mothers $<30$ years of age and whose mother had smoked during pregnancy, and fewer with a mother that had a BMI $\geq 25$. There were also more who had been first-born children and who were born at term, while fewer were born moderately preterm. Though the differences between groups were 
significant, the absolute numbers were small and regarded as not affecting the validity of the study results.

The distribution of maternal BMI differed between mothers of control children and mothers of children who later developed T1D ( $\mathrm{p}=0.02)$, where the latter were more likely to be obese (9.0\% vs $7.7 \%$, Table 4$)$. A subgroup analysis of offspring of mothers without diabetes showed the same result, with more obese mothers of children who later developed T1D compared with controls (8.8\% vs 7.6\%; $\mathrm{p}=0.04)$. However, this was not found in offspring of mothers with diabetes (Table 5).

Table 4 Maternal characteristics of children with and without T1D

\begin{tabular}{|c|c|c|c|}
\hline Maternal characteristic & $\begin{array}{l}\text { Control children } \\
(n=12,948)\end{array}$ & $\begin{array}{l}\text { Index children } \\
(n=3,231)\end{array}$ & $p$-value ${ }^{\mathrm{a}}$ \\
\hline \multicolumn{4}{|l|}{ BMI } \\
\hline Underweight $(<18.5$ kg/m²) & $530(4.1)$ & $110(3.4)$ & 0.02 \\
\hline Normal weight $\left(18.5-24.9 \mathrm{~kg} / \mathrm{m}^{2}\right)$ & $8,769(67.7)$ & $2,149(66.5)$ & \\
\hline Overweight $\left(25.0-29.9 \mathrm{~kg} / \mathrm{m}^{2}\right)$ & $2,658(20.5)$ & $680(21.1)$ & \\
\hline Obese $\left(\geq 30.0 \mathrm{~kg} / \mathrm{m}^{2}\right)$ & $991(7.7)$ & $292(9.0)$ & \\
\hline \multicolumn{4}{|l|}{ GWG according to IOM } \\
\hline Inadequate & $3,127(24.2)$ & $717(22.2)$ & 0.06 \\
\hline Adequate & $5,091(39.3)$ & $1,301(40.3)$ & \\
\hline Excessive & $4,730(36.5)$ & $1,213(37.5)$ & \\
\hline \multicolumn{4}{|l|}{ Maternal age } \\
\hline $13-29$ years & $7,492(57.9)$ & $1,794(55.5)$ & 0.02 \\
\hline$\geq 30$ years & $5,456(42.1)$ & $1,437(44.5)$ & \\
\hline \multicolumn{4}{|l|}{ Pregnancy length } \\
\hline Very preterm $(<32$ weeks $)$ & $53(0.4)$ & $10(0.3)$ & 0.24 \\
\hline Moderately preterm (32-36 weeks) & $561(4.3)$ & $164(5.1)$ & \\
\hline Term (37-41 weeks) & $12,262(94.7)$ & $3,037(94.0)$ & \\
\hline Post-term ( $\geq 42$ weeks) & $72(0.6)$ & $20(0.6)$ & \\
\hline \multicolumn{4}{|l|}{ Parity } \\
\hline Primipara & $5,681(43.9)$ & $1,389(43.0)$ & 0.36 \\
\hline Multipara & $7,267(56.1)$ & $1,842(57.0)$ & \\
\hline \multicolumn{4}{|l|}{ Smoking during pregnancy } \\
\hline No & $9,971(79.1)$ & $2,551(80.8)$ & 0.04 \\
\hline Yes, at any time during pregnancy & $2,634(20.9)$ & $607(19.2)$ & \\
\hline \multicolumn{4}{|l|}{ Maternal diabetes } \\
\hline No & $12,840(99.2)$ & $3,141(97.2)$ & $<0.001$ \\
\hline Yes, any form of diabetes & $108(0.8)$ & $90(2.8)$ & \\
\hline
\end{tabular}

Data are given as $n(\%)$. In MBR there is missing data for 416 women (2.6\%) on smoking during pregnancy.

${ }^{\text {a }}$ Pearson $\chi^{2}$ test: control children vs index children

In the multivariate analysis a child whose mother had been obese in early pregnancy had an increased risk of T1D (crude OR 1.20; 95\% CI 1.05 - 1.38) and this result remained after 
adjusting for GWG, maternal age, maternal parity, maternal smoking, maternal diabetes, and pregnancy length (adjusted OR 1.18; 95\% CI 1.02 - 1.36, Table 6).

Table 5 Risk of T1D in offspring in relation to maternal diabetes and maternal BMI class

\begin{tabular}{llllll}
\hline \multirow{2}{*}{ Maternal BMI } & \multicolumn{2}{c}{$\begin{array}{c}\text { No maternal diabetes } \\
(n=15,981)^{\dagger}\end{array}$} & & \multicolumn{2}{c}{$\begin{array}{c}\text { Maternal diabetes } \\
(n=198)^{\ddagger}\end{array}$} \\
\cline { 2 - 3 } \cline { 5 - 6 } & $\begin{array}{l}\text { Control } \\
\text { children }\end{array}$ & $\begin{array}{l}\text { Index } \\
\text { children }\end{array}$ & & $\begin{array}{l}\text { Control } \\
\text { children }\end{array}$ & $\begin{array}{l}\text { Index } \\
\text { children }\end{array}$ \\
\hline Underweight $\left(<18.5 \mathrm{~kg} / \mathrm{m}^{2}\right)$ & $529(4.1)$ & $110(3.5)$ & & $1(0.9)$ & $0(0.0)$ \\
Normal weight $\left(18.5-24.9 \mathrm{~kg} / \mathrm{m}^{2}\right)$ & $8,711(67.8)$ & $2,100(66.9)$ & $58(53.7)$ & $49(54.4)$ \\
Overweight $\left(25.0-29.9 \mathrm{~kg} / \mathrm{m}^{2}\right)$ & $2,628(20.5)$ & $654(20.8)$ & & $30(27.8)$ & $26(28.9)$ \\
Obese $\left(\geq 30.0 \mathrm{~kg} / \mathrm{m}^{2}\right)$ & $972(7.6)$ & $277(8.8)$ & & $19(17.6)$ & $15(16.7)$ \\
\hline
\end{tabular}

Data are given as $n(\%) .{ }^{\dagger}$ and ${ }^{\ddagger}$ Pearson $\chi^{2}$ test: control children vs index children, ${ }^{\dagger} p=0.04 .{ }^{\star} p=0.83$

There was no statistically significant difference in GWG, a result that remained when analyzing only those giving birth at term. However, a further analysis showed that underweight mothers with an inadequate GWG were less likely to have a child who later developed T1D compared to underweight mothers with both adequate and excessive GWG ( $\mathrm{p}=0.04$ for both). In the multivariate analysis an inadequate GWG seemed to be a protective factor (crude OR 0.90; 95\% CI 0.81-0.99); however, the significance disappeared in the adjusted model (Table 6).

Maternal BMI was also included in the regression analysis in study III, as it is a confounder to the child's size for gestational age, and the results showed that both maternal overweight and obesity increased the risk of T1D in the child. If the mother had been overweight the OR for a child to develop T1D was 1.09 (95\% CI 1.02 - 1.16) and this remained, though it was slightly less significant, when adjusted for confounding factors (adjusted OR 1.07; 95\% CI 1.00 1.14). For maternal obesity the corresponding figures were crude OR 1.26 (95\% CI 1.15 1.38) and adjusted OR 1.22 (95\% CI 1.11 - 1.34) (Table 7).

There was no significant difference in maternal BMI between children with T1D when they were divided into different HLA genotype groups (Table 8). The mean maternal BMI ranged from 24.3 to $24.5 \mathrm{~kg} / \mathrm{m}^{2}$ in the four HLA genotype groups. 
Table 6 ORs for developing T1D depending on different maternal characteristics

\begin{tabular}{|c|c|c|}
\hline Maternal characteristic & Crude OR (95\% CI) & Adjusted OR (95\% CI) \\
\hline \multicolumn{3}{|l|}{ BMI } \\
\hline Underweight $(<18.5$ kg/m²) & $0.85(0.69-1.05)$ & $0.89(0.71-1.10)$ \\
\hline Normal weight $\left(18.5-24.9 \mathrm{~kg} / \mathrm{m}^{2}\right)$ & Reference & Reference \\
\hline Overweight $\left(25.0-29.9 \mathrm{~kg} / \mathrm{m}^{2}\right)$ & $1.04(0.95-1.15)$ & $1.01(0.91-1.12)$ \\
\hline Obese $\left(\geq 30.0 \mathrm{~kg} / \mathrm{m}^{2}\right)$ & $1.20(1.05-1.38)$ & $1.18(1.02-1.36)$ \\
\hline \multicolumn{3}{|l|}{ GWG according to IOM } \\
\hline Inadequate & $0.90(0.81-0.99)$ & $0.90(0.81-1.00)$ \\
\hline Adequate & Reference & Reference \\
\hline Excessive & $1.00(0.92-1.10)$ & $0.99(0.90-1.09)$ \\
\hline \multicolumn{3}{|l|}{ Maternal age } \\
\hline 13-29 years & Reference & Reference \\
\hline$\geq 30$ years & $1.10(1.02-1.19)$ & $1.08(0.99-1.17)$ \\
\hline \multicolumn{3}{|l|}{ Pregnancy length } \\
\hline Very preterm $(<32$ weeks $)$ & $0.76(0.39-1.50)$ & $0.65(0.33-1.38)$ \\
\hline Moderately preterm (32-36 weeks) & $1.18(0.99-1.41)$ & $1.15(0.96-1.38)$ \\
\hline Term (37-41 weeks) & Reference & Reference \\
\hline Post-term ( $\geq 42$ weeks) & $1.12(0.68-1.84)$ & $1.07(0.63-1.80)$ \\
\hline \multicolumn{3}{|l|}{ Parity } \\
\hline Primipara & Reference & Reference \\
\hline Multipara & $1.04(0.96-1.12)$ & $1.01(0.93-1.10)$ \\
\hline \multicolumn{3}{|l|}{ Smoking during pregnancy } \\
\hline No & Reference & Reference \\
\hline Yes, at any time during pregnancy & $0.90(0.82-0.99)$ & $0.91(0.82-1.00)$ \\
\hline \multicolumn{3}{|l|}{ Maternal diabetes } \\
\hline No & Reference & Reference \\
\hline Yes, any form of diabetes & $3.41(2.57-4.52)$ & $3.31(2.49-4.40)$ \\
\hline
\end{tabular}

Adjusted OR includes maternal BMI, GWG, maternal age, pregnancy length, maternal parity, maternal smoking habits and maternal diabetes

\section{MATERNAL DIABETES}

Compared to mothers without diabetes, mothers with diabetes were older at childbirth $(30.55$ years \pm 5.2 years vs 29.03 years \pm 5.1 years, $\mathrm{p}<0.001)$ and had a significantly higher BMI $(\mathrm{p}<0.001)$. The proportion of mothers who were older than 30 years of age when giving birth was also higher among women with diabetes; $58.9 \%$ vs $45.1 \%$ in women without diabetes $(\mathrm{p}<0.001)$. Only $0.9 \%(\mathrm{n}=328)$ of control children had a mother with diabetes compared with $2.9 \%(n=276)$ of children who later developed T1D. The difference was even more pronounced when comparing mothers with T1D. Of the 604 mothers with diabetes 213 had T1D, and of these, 73 were mothers of control children $(0.4 \%)$ and $140(3.2 \%)$ mothers of children who later developed T1D ( $\mathrm{p}<0.001)$. 
Table 7 ORs for developing T1D depending on different infant and maternal characteristics

\begin{tabular}{|c|c|c|c|}
\hline Characteristics & $\begin{array}{c}\text { Crude OR } \\
(95 \% \text { CI })\end{array}$ & $\begin{array}{c}\text { Adjusted OR } \\
(95 \% \mathrm{CI})^{\mathrm{a}}\end{array}$ & $\begin{array}{c}\text { Adjusted OR } \\
(95 \% \mathrm{CI})^{\mathrm{b}}\end{array}$ \\
\hline \multicolumn{4}{|l|}{ Size for gestational age } \\
\hline AGA & Reference & Reference & Reference \\
\hline SGA & $0.76(0.65-0.90)$ & $0.80(0.66-0.98)$ & $0.76(0.63-0.92)$ \\
\hline LGA & $1.34(1.20-1.50)$ & $1.15(1.01-1.31)$ & $1.16(1.02-1.32)$ \\
\hline \multicolumn{4}{|l|}{ Gestational age } \\
\hline Very preterm (<32 weeks) & $0.69(0.50-0.95)$ & $0.70(0.46-1.07)$ & $0.69(0.47-1.02)$ \\
\hline Moderately preterm (32-36 weeks) & $1.11(1.01-1.23)$ & $1.10(0.97-1.24)$ & $1.06(0.94-1.19)$ \\
\hline Term (37-41 weeks) & Reference & Reference & Reference \\
\hline Post-term ( $\geq 42$ weeks $)$ & $0.87(0.63-1.20)$ & $0.91(0.62-1.34)$ & $0.92(0.62-1.35)$ \\
\hline \multicolumn{4}{|l|}{ Maternal diabetes } \\
\hline No & Reference & Reference & NA \\
\hline Yes, any form of diabetes & $3.51(2.98-4.14)$ & $3.34(2.77-4.03)$ & NA \\
\hline \multicolumn{4}{|l|}{ Maternal BMI } \\
\hline Underweight $\left(<18.5 \mathrm{~kg} / \mathrm{m}^{2}\right)$ & $0.86(0.74-1.01)$ & $0.90(0.77-1.05)$ & NA \\
\hline Normal weight $\left(18.5-24.9 \mathrm{~kg} / \mathrm{m}^{2}\right)$ & Reference & Reference & NA \\
\hline Overweight $\left(25.0-29.9 \mathrm{~kg} / \mathrm{m}^{2}\right)$ & $1.09(1.02-1.16)$ & $1.07(1.00-1.14)$ & NA \\
\hline Obese $\left(\geq 30 \mathrm{~kg} / \mathrm{m}^{2}\right)$ & $1.26(1.15-1.38)$ & $1.22(1.11-1.34)$ & NA \\
\hline \multicolumn{4}{|l|}{ Maternal diabetes and BMI } \\
\hline No maternal diabetes \& BMI $<25 \mathrm{~kg} / \mathrm{m}^{2}$ & Reference & NA & Reference \\
\hline No maternal diabetes \& BMI $\geq 25 \mathrm{~kg} / \mathrm{m}^{2}$ & $1.12(1.06-1.19)$ & NA & $1.12(1.06-1.18)$ \\
\hline Maternal diabetes \& BMI $<25 \mathrm{~kg} / \mathrm{m}^{2}$ & $3.79(2.91-4.94)$ & NA & $3.64(2.79-4.74)$ \\
\hline Maternal diabetes \& $\mathrm{BMI} \geq 25 \mathrm{~kg} / \mathrm{m}^{2}$ & $3.60(2.79-4.65)$ & NA & $3.52(2.71-4.55)$ \\
\hline \multicolumn{4}{|l|}{ Maternal smoking during pregnancy } \\
\hline No & Reference & Reference & Reference \\
\hline Yes, at any time during pregnancy & $0.84(0.79-0.90)$ & $0.86(0.80-0.92)$ & $0.86(0.80-0.92)$ \\
\hline \multicolumn{4}{|l|}{ Maternal age } \\
\hline $13-29$ years & Reference & Reference & Reference \\
\hline$\geq 30$ years & $1.05(1.00-1.10)$ & $1.04(0.98-1.10)$ & $1.04(0.99-1.10)$ \\
\hline \multirow{2}{*}{\multicolumn{4}{|c|}{$\begin{array}{l}{ }^{\mathrm{a}} \text { Adjusted OR includes size for gestational age, gestational age, maternal diabetes, maternal BMI, maternal smoking habits } \\
\text { and maternal age } \\
\mathrm{b} \text { Adjusted OR includes size for gestational age, gestational age, the combination variable of maternal diabetes and BMI, } \\
\text { maternal smoking habits and maternal age. } \\
\text { NA, not applicable }\end{array}$}} \\
\hline & & & \\
\hline \multicolumn{4}{|c|}{ An unexpected result in study I was that in offspring of mothers with diabetes there was a } \\
\hline \multicolumn{4}{|c|}{ higher degree of development of T1D among girls compared to boys ( $3.1 \%$ vs $2.8 \%$ ). This } \\
\hline \multicolumn{4}{|c|}{ was even more pronounced if the mother had T1D, where $3.5 \%$ of girls and $3.0 \%$ of boys } \\
\hline \multicolumn{4}{|c|}{ developed T1D. However, both boys and girls were more likely to develop T1D if the mother } \\
\hline \multicolumn{4}{|c|}{ had diabetes, a result which was strengthened when restricting the comparison to mothers } \\
\hline \multicolumn{4}{|c|}{ with and without T1D (61.3\% vs $19.5 \%$ for boys and $70.6 \%$ vs $19.5 \%$ for girls, $p<0.001$} \\
\hline espectively). & & & \\
\hline
\end{tabular}


There was also a significant difference in BMI $(\mathrm{p}<0.001)$ between women with and without diabetes. In women with GDM $27.1 \%$ were obese, compared to $14.9 \%$ of women with T1D and $11.2 \%$ of women without diabetes.

Maternal diabetes was the strongest risk factor for T1D in the offspring in studies I - III. In study I the crude OR for the offspring to develop T1D was 3.44 (95\% CI $2.92-4.04)$ if the mother had diabetes and if the mother had T1D the OR increased to 7.9 (95\% CI 5.94 10.50, Table 3). In study II the crude OR for T1D in the offspring if the mother had diabetes was $3.41(95 \%$ CI $2.57-4.52)$ and in the adjusted analysis it decreased only slightly to 3.31 (95\% CI $2.49-4.40$, Table 6). A subgroup analysis of the women pregnant in 1997 and thereafter, where division of diabetes into T1D $(n=67)$ or GDM $(n=70)$ was possible, showed that maternal T1D was associated with the highest risk of the child developing T1D (crude OR 5.13; 95\% CI 3.16 - 8.33; adjusted OR 4.75; 95\% CI 2.19-7.75). Moreover, GDM was also associated with an increased risk of T1D in the child (crude OR 1.78; 95\% CI 1.07 2.98; adjusted OR 1.81; 95\% CI 1.08 - 3.04). In study III the crude OR for T1D was 3.51 (95\% CI $2.98-4.14)$ and adjusted OR 3.34 (95\% CI 2.77 - 4.03, Table 7) if the mother had diabetes.

There was no difference in the proportion of maternal diabetes between the different HLA genotype groups among children with T1D (Table 8).

\section{OTHER MATERNAL CHARACTERISTICS}

\section{Maternal age}

The mean maternal age at childbirth was almost the same in mothers of children with T1D $(29.16 \pm 5.1$ years $)$ and mothers of control children $(29.02 \pm 5.1$ years $)$.

In study II, children with T1D more often had an older mother ( $\geq 30$ years) compared to control children $(44.5 \%$ vs $42.1 \%, \mathrm{p}=0.02$, Table 4$)$, a result that was the same, but slightly less significant in study III (46.0\% vs $44.8 \%, \mathrm{p}=0.048$, Table 9). However, in both studies II and III the association of a higher risk of T1D in the child with maternal age disappeared in the adjusted regression analysis (Table 6 and 7).

There was a significant difference in maternal age between the HLA genotype groups ( $\mathrm{p}<0.001$ ) among children with T1D. A higher proportion of children with DQ2/8 and DQ8/X had an older mother (i.e., age $\geq 30$ years, $52.8 \%$ and $51.3 \%$ vs $44.2 \%$ with DQ2/X and $44.1 \%$ with DQX/X, Table 8). This association was found in both sexes (data not shown). 
Table 8 Characteristics of children with T1D and their mothers in relation to the HLA genotype.

\begin{tabular}{|c|c|c|c|c|c|}
\hline \multirow[b]{2}{*}{ Characteristics } & \multicolumn{4}{|c|}{ HLA genotype } & \multirow[b]{2}{*}{ p-value* } \\
\hline & $\begin{array}{l}\text { DQ2/8 } \\
n=1,351\end{array}$ & $\begin{array}{l}\text { DQ8/X } \\
\mathrm{n}=1,963\end{array}$ & $\begin{array}{l}\text { DQ2/X } \\
n=733\end{array}$ & $\begin{array}{l}\mathbf{D Q} \mathbf{X} / \mathbf{X} \\
\mathrm{n}=469\end{array}$ & \\
\hline \multicolumn{6}{|l|}{ Maternal BMI (kg/m²) } \\
\hline Underweight $(<18.5)$ & $25(2.2)$ & $29(1.9)$ & $21(3.5)$ & $12(3.2)$ & \multirow[t]{5}{*}{0.364} \\
\hline Normal weight (18.5-24.9) & $716(64.0)$ & $976(62.7)$ & $357(58.6)$ & $237(63.0)$ & \\
\hline Overweight (25-29.9) & $260(23.3)$ & $388(24.9)$ & $162(26.6)$ & $81(21.6)$ & \\
\hline Obese (30-34.9) & $87(7.8)$ & $117(7.5)$ & $53(8.7)$ & $35(9.3)$ & \\
\hline Morbidly Obese $(\geq 35)$ & $30(2.7)$ & $47(3.0)$ & $16(2.6)$ & $11(2.9)$ & \\
\hline \multicolumn{6}{|l|}{ Maternal age } \\
\hline 13-29 years & $6,121(47.2)$ & $956(48.7)$ & $409(55.8)$ & $262(55.9)$ & \multirow[t]{2}{*}{$<0.001$} \\
\hline$\geq 30$ years & $694(52.8)$ & $1,007(51.3)$ & $324(44.2)$ & $207(44.1)$ & \\
\hline \multicolumn{6}{|l|}{ Maternal smoking } \\
\hline No & $1,043(83.0)$ & $1,580(84.1)$ & $583(83.0)$ & $367(82.5)$ & \multirow[t]{2}{*}{0.766} \\
\hline Yes, at any time & $214(17.0)$ & $299(15.9)$ & $119(17.0)$ & $78(17.5)$ & \\
\hline \multicolumn{6}{|l|}{ Maternal Parity } \\
\hline Primipara & $522(39.7)$ & $840(42.8)$ & $318(43.4)$ & $196(41.8)$ & \multirow[t]{2}{*}{0.266} \\
\hline Multipara & $793(60.3)$ & $1,122(57.2)$ & $415(56.6)$ & $273(58.2)$ & \\
\hline \multicolumn{6}{|l|}{ Maternal diabetes } \\
\hline No & $1,277(97.1)$ & $1,883(95.9)$ & $710(96.9)$ & $458(97.7)$ & \multirow[t]{2}{*}{0.137} \\
\hline Yes, any form of diabetes & $38(2.9)$ & $80(4.1)$ & $23(3.1)$ & $11(2.3)$ & \\
\hline \multicolumn{6}{|l|}{ Birthweight } \\
\hline Low $(<2,500 \mathrm{~g})$ & $30(2.3)$ & $48(2.5)$ & $21(2.9)$ & $22(4.7)$ & \multirow[t]{3}{*}{0.025} \\
\hline Normal $(2,500-3,999 \mathrm{~g})$ & $965(73.5)$ & $1,498(76.5)$ & $558(76.4)$ & $337(72.0)$ & \\
\hline Macrosomia $(\geq 4,000 \mathrm{~g})$ & $317(24.2)$ & $412(21.0)$ & $151(20.7)$ & $109(23.3)$ & \\
\hline \multicolumn{6}{|l|}{ Size for age } \\
\hline SGA & $20(1.5)$ & $31(1.6)$ & $18(2.5)$ & $13(2.7)$ & \multirow[t]{3}{*}{0.270} \\
\hline AGA & $127(93.3)$ & $1,824(92.9)$ & $684(93.3)$ & $436(93.0)$ & \\
\hline LGA & $68(5.2)$ & $108(5.5)$ & $31(4.2)$ & $20(4.3)$ & \\
\hline \multicolumn{6}{|l|}{ Gestational age } \\
\hline Preterm (<37 weeks) & $67(5.1)$ & $125(6.4)$ & $40(5.4)$ & $36(7.7)$ & \multirow[t]{3}{*}{0.369} \\
\hline Term (37-41 weeks) & $1,242(94.5)$ & $1,829(93.2)$ & $688(93.9)$ & $430(91.7)$ & \\
\hline Post-term ( $\geq 42$ weeks) & $5(0.4)$ & $8(0.4)$ & $5(0.7)$ & $3(0.6)$ & \\
\hline \multicolumn{6}{|l|}{ Sex } \\
\hline Boy & $745(56.7)$ & $1,059(53.9)$ & $401(54.7)$ & $262(55.9)$ & \multirow[t]{2}{*}{0.477} \\
\hline Girl & $570(43.3)$ & $904(46.1)$ & $332(45.3)$ & $207(44.1)$ & \\
\hline \multicolumn{6}{|l|}{ Age at onset of T1D } \\
\hline $0-4$ years & $254(19.3)$ & $256(13.1)$ & $120(16.4)$ & $49(10.4)$ & \multirow[t]{4}{*}{$<0.001$} \\
\hline 5-9 years & $415(31.6)$ & $619(31.5)$ & $216(29.5)$ & $129(27.5)$ & \\
\hline $10-14$ years & $458(34.8)$ & $717(36.5)$ & $275(37.5)$ & $188(40.1)$ & \\
\hline $15-18$ years & $188(14.3)$ & $371(18.9)$ & $122(16.6)$ & $103(22.0)$ & \\
\hline
\end{tabular}

Data are given as $\mathrm{n}(\%) . \quad$ *Pearson's $\chi 2$ test between children with different genotypes

\section{Maternal smoking}

Mothers of children who developed T1D were less likely to be smokers. In study II this was found in the univariate analysis ( $\mathrm{p}=0.04$, Table 4 ) and in the unadjusted logistic regression, but in the adjusted analysis the significance disappeared (Table 6).

The larger study population in study III also showed that mothers of children with T1D smoked less often $(17.7 \%$ vs $20.3 \%$, p<0.001, Table 9$)$ and the multivariate analysis showed a 
decreased risk of T1D in the child with maternal smoking even after adjustment (crude OR 0.84 95\% [CI 0.79 - 0.90]; adjusted OR 0.86 [95\% CI 0.80 - 0.92], Table 7).

Table 9 Characteristics of children with and without T1D and their mothers

\begin{tabular}{|c|c|c|c|}
\hline Characteristics & $\begin{array}{l}\text { Control children } \\
\mathrm{n}(\%)\end{array}$ & $\begin{array}{c}\text { Index children } \\
\mathrm{n}(\%)\end{array}$ & p-value \\
\hline \multicolumn{4}{|l|}{ Size for gestational age } \\
\hline AGA & 34,789 (93.9) & $8,661(93.3)$ & \multirow[t]{3}{*}{$<0.001$} \\
\hline SGA & $962(2.6)$ & $183(2.0)$ & \\
\hline LGA & $1,299(3.5)$ & $434(4.7)$ & \\
\hline \multicolumn{4}{|l|}{ Gestational age } \\
\hline Very preterm (<32 weeks) & $261(0.7)$ & $45(0.5)$ & \multirow[t]{4}{*}{0.014} \\
\hline Moderately preterm (32-36 weeks) & $1,799(4.9)$ & $501(5.4)$ & \\
\hline Term (37-41 weeks) & 34,730 (93.9) & $8,680(93.6)$ & \\
\hline Post-term ( $\geq 42$ weeks) & $207(0.5)$ & $45(0.5)$ & \\
\hline \multicolumn{4}{|l|}{ Maternal diabetes } \\
\hline No & $36,733(99.1)$ & $9,005(97.1)$ & \multirow[t]{2}{*}{$<0.001$} \\
\hline Yes, any form of diabetes & $317(0.9)$ & $273(2.9)$ & \\
\hline \multicolumn{4}{|l|}{ Maternal BMI } \\
\hline Underweight $\left(<18.5 \mathrm{~kg} / \mathrm{m}^{2}\right)$ & $936(3.4)$ & $198(2.8)$ & \multirow[t]{4}{*}{$<0.001$} \\
\hline Normal weight $\left(18.5-24.9 \mathrm{~kg} / \mathrm{m}^{2}\right)$ & $18,217(66.4)$ & $4,460(64.1)$ & \\
\hline Overweight $\left(25.0-29.9 \mathrm{~kg} / \mathrm{m}^{2}\right)$ & $6,039(22.0)$ & $1,611(23.2)$ & \\
\hline Obese $\left(\geq 30 \mathrm{~kg} / \mathrm{m}^{2}\right)$ & $2,248(8.2)$ & $691(9.9)$ & \\
\hline \multicolumn{4}{|l|}{ Maternal diabetes and BMI } \\
\hline No maternal diabetes \& BMI<25 & $19,036(69.4)$ & 4,551 (65.4) & \multirow[t]{4}{*}{$<0.001$} \\
\hline No maternal diabetes \& $\mathrm{BMI} \geq 25$ & $8,158(29.7)$ & 2,191 (31.5) & \\
\hline Maternal diabetes \& BMI<25 & $118(0.4)$ & $107(1.5)$ & \\
\hline Maternal diabetes \& $\mathrm{BMI} \geq 25$ & $129(0.5)$ & $111(1.6)$ & \\
\hline \multicolumn{4}{|l|}{ Weight gain during pregnancy } \\
\hline Adequate & $5,061(39.4)$ & $1,292(40.4)$ & \multirow[t]{3}{*}{0.063} \\
\hline Excessive & $4,664(36.3)$ & $1,194(37.3)$ & \\
\hline Inadequate & $3,116(24.3)$ & $713(22.3)$ & \\
\hline \multicolumn{4}{|l|}{ Maternal smoking during pregnancy } \\
\hline No & $28,037(79.7)$ & $7,300(82.3)$ & \multirow[t]{2}{*}{$<0.001$} \\
\hline Yes, at any time during pregnancy & 7,158 (20.3) & $1,570(17.7)$ & \\
\hline \multicolumn{4}{|l|}{ Age } \\
\hline 13-29 years & $20,445(55.2)$ & $5,014(54.0)$ & \multirow[t]{2}{*}{0.048} \\
\hline$\geq 30$ years & $16,605(44.8)$ & $4,264(46.0)$ & \\
\hline
\end{tabular}

Data are given as $n(\%) . \quad{ }^{\text {a }}$ Pearson $\chi^{2}$ test: control children vs index children

There was no difference in the proportion of mothers who had smoked between the different HLA genotype groups among children with T1D (Table 8).

\section{SIZE FOR GESTATIONAL AGE AND BIRTHWEIGHT}

Most children were born AGA (93.8\%), while 3.7\% were born LGA and 2.5\% SGA, with no significant sex differences. Children born LGA, compared to AGA or SGA, more often had an older mother $(53.6 \%$ vs $44.7 \%$ and $44.0 \%$ respectively, $\mathrm{p}<0.001)$ or a mother with diabetes 
( $7.8 \%$ vs $1.0 \%$ and $0.7 \%$ respectively, $\mathrm{p}<0.001)$, and were less likely to be a first-born child $(22.7 \%$ vs $42.4 \%$ and $57.5 \%$, p<0.001). Maternal smoking was more common among children born SGA than those born AGA and LGA (33.6\% vs $19.8 \%$ and $12.0 \%, \mathrm{p}<0.001)$. With increasing maternal BMI, the proportion of children born LGA increased, and the proportion of SGA decreased $(\mathrm{p}<0.001)$. The proportion of LGA also increased and SGA decreased with a GWG going from inadequate to adequate to excessive. In addition, size for gestational age differed with respect to pregnancy length $(\mathrm{p}<0.001$, Table 10$)$.

Table 10 Maternal characteristics of children with and without T1D in relation to size for gestational age

\begin{tabular}{|c|c|c|c|c|}
\hline \multirow[b]{2}{*}{ Characteristics } & \multicolumn{3}{|c|}{ Size for gestational age } & \multirow[b]{2}{*}{ p-value } \\
\hline & $\begin{array}{l}\text { SGA } \\
\mathrm{n}(\%)\end{array}$ & $\begin{array}{l}\text { AGA } \\
\mathrm{n}(\%)\end{array}$ & $\begin{array}{l}\text { LGA } \\
\mathrm{n}(\%)\end{array}$ & \\
\hline \multicolumn{5}{|l|}{ Maternal Diabetes } \\
\hline Yes, any form of diabetes & $8(0.7)$ & $447(1.0)$ & $135(7.8)$ & \multirow[t]{2}{*}{ p $<0.001$} \\
\hline No & $1,137(99.3)$ & $43,003(99.0)$ & $1,598(92.2)$ & \\
\hline \multicolumn{5}{|l|}{ Maternal BMI } \\
\hline Underweight $\left(<18.5 \mathrm{~kg} / \mathrm{m}^{2}\right)$ & $54(6.9)$ & $1,066(3.3)$ & $15(1.2)$ & \multirow[t]{4}{*}{$\mathrm{p}<0.001$} \\
\hline Normal Weight $\left(18.5-24.9 \mathrm{~kg} / \mathrm{m}^{2}\right)$ & $540(69.1)$ & $21,505(66.6)$ & $632(47.0)$ & \\
\hline Overweight $\left(25.0-29.9 \mathrm{~kg} / \mathrm{m}^{2}\right)$ & $137(17.5)$ & $7,065(21.9)$ & $448(33.3)$ & \\
\hline Obese $\left(\geq 30 \mathrm{~kg} / \mathrm{m}^{2}\right)$ & $51(6.5)$ & $2,639(8.2)$ & $249(18.5)$ & \\
\hline \multicolumn{5}{|l|}{ Maternal GWG } \\
\hline Inadequate & $138(36.9)$ & $3,636(24.2)$ & $55(8.8)$ & \multirow[t]{3}{*}{$\mathrm{p}<0.001$} \\
\hline Adequate & $145(38.8)$ & $6,008(39.9)$ & $200(32.0)$ & \\
\hline Excessive & $91(25.3)$ & $5,397(35.9)$ & $370(59.2)$ & \\
\hline \multicolumn{5}{|l|}{ Maternal age } \\
\hline 13-29 years & $641(56.0)$ & $24,014(55.3)$ & $804(46.4)$ & \multirow[t]{2}{*}{$\mathrm{p}<0.001$} \\
\hline$\geq 30$ years & $504(44.0)$ & $19,436(44.7)$ & $929(53.6)$ & \\
\hline \multicolumn{5}{|l|}{ Maternal parity } \\
\hline Primipara & $658(57.5)$ & $18,417(42.4)$ & $393(22.7)$ & \multirow[t]{2}{*}{$\mathrm{p}<0.001$} \\
\hline Multipara & $487(42.5)$ & $25,030(57.6)$ & $1,340(77.3)$ & \\
\hline \multicolumn{5}{|l|}{ Maternal smoking } \\
\hline Yes, at any time during pregnancy & $359(33.6)$ & $8,169(19.8)$ & $200(12.0)$ & \multirow[t]{2}{*}{$\mathrm{p}<0.001$} \\
\hline No & $708(66.4)$ & $33,166(80.2)$ & $1,463(88.0)$ & \\
\hline \multicolumn{5}{|l|}{ Gestational age } \\
\hline Very preterm $(<32$ weeks $)$ & $64(5.6)$ & $233(0.6)$ & $9(0.5)$ & \multirow[t]{4}{*}{$\mathrm{p}<0.001$} \\
\hline Moderately preterm (32-36 weeks) & $211(18.4)$ & $1,955(4.5)$ & $134(7.7)$ & \\
\hline Term (37-41 weeks) & $859(75.0)$ & $40,966(94.4)$ & $1,585(91.5)$ & \\
\hline Post-term ( $\geq 42$ weeks) & $11(1.0)$ & $236(0.5)$ & $5(0.3)$ & \\
\hline \multicolumn{5}{|l|}{ Sex } \\
\hline Boys & $623(54.4)$ & $24,031(55.3)$ & $920(53.1)$ & \multirow[t]{2}{*}{0.164} \\
\hline Girls & $522(45.6)$ & $19,419(44.7)$ & $813(46.9)$ & \\
\hline
\end{tabular}

${ }^{\mathrm{a}}$ Pearson $\chi^{2}$ test: SGA vs AGA vs LGA

Size for gestational age and birthweight differed between children with T1D and control children ( $\mathrm{p}<0.001$, respectively). Children with T1D were more often born LGA (4.7\% vs $3.5 \%)$ and less often born SGA (2.0\% vs $2.6 \%$, Table 9). This was the same when using the broader definition of LGA and SGA (weight above the $90^{\text {th }}$ or below the $10^{\text {th }}$ percentile for 
that gestational age). More children with T1D had been born with a birthweight of $\geq 4,000 \mathrm{~g}$ (macrosomia), and fewer were born with a low $(1,500-2,499 \mathrm{~g})$ or very low $(<1,500 \mathrm{~g})$ birthweight. In children born at term, the figures were a little more evenly distributed but the statistical significance remained for both size for gestational age and birthweight $(\mathrm{p}<0.001$ and $\mathrm{p}=0.001$, respectively).

In simple logistic regression (Table 7), being born LGA increased the risk of developing T1D (crude OR 1.34 [95\% CI 1.20 - 1.50]) and SGA decreased the risk (crude OR 0.76 [95\% CI $0.65-0.90]$ ) compared to being born AGA. Since several variables that have been shown to affect T1D also differed depending on size for gestational age, the logistic regression model was adjusted for the following variables: maternal diabetes, maternal BMI, maternal smoking, maternal age, and gestational age. Since information on GWG only was available for $34.5 \%$ of the mothers, the possible effect of including this variable as a confounder was evaluated. The models yielded an unchanged OR for the effect of SGA on the risk of developing T1D, and the risk of being born LGA only slightly decreased $(<10 \%)$. For this reason, and since we could not verify an association between GWG and T1D in study II, GWG was not included as a confounder in the analysis. The significant results remained after adjustment with an adjusted OR for developing T1D of 1.16 (95\% CI 1.02 - 1.32) for LGA and 0.76 (95\% CI $0.63-0.92$ ) for SGA (Table 7). The result was the same when excluding cases assumed to be AGA.

To further investigate whether LGA was truly an independent risk factor for T1D, regardless of maternal BMI and maternal diabetes, a new variable was created. Based on maternal diabetes and BMI, children were subdivided into four categories and the result was the same with children born LGA having an increased risk of T1D even if their mothers had a BMI $<25$ $\mathrm{kg} / \mathrm{m}^{2}$ and did not have diabetes (Table 7).

There was no difference in size for gestational age between the different HLA genotype groups among children with T1D. Birthweight, however, was different between the groups $(\mathrm{p}=0.025$, Table 8$)$ and a subgroup analysis, with Bonferroni adjustment, showed that the difference was primarily that children with DQX/X were more often born with a low birthweight $(<2,500 \mathrm{~g})$ compared to those with $\mathrm{DQ} 8 / \mathrm{X}(\mathrm{p}=0.028)$, whereas the difference to DQ8/2 did not quite reach statistical significance $(\mathrm{p}=0.058)$. The difference in absolute birthweight was small ( $\mathrm{p}=0.043)$ ranging from 3,623 $\mathrm{g}(95 \%$ CI 3,593 $\mathrm{g}-3,653 \mathrm{~g})$ for those with DQ2/8 down to 3,548 $\mathrm{g}(95 \% \mathrm{CI} 3,498 \mathrm{~g}-3,598 \mathrm{~g})$ for those with DQX/X and a post hoc test with Tukey adjustment did not quite reach significance ( $p=0.057$ between $D Q 2 / 8$ and 
DQX/X). In addition, when controlling for the confounder 'maternal age', the significance in the primary model disappeared $(\mathrm{p}=0.05)$.

In the multinomial regression analysis, where children with low birthweight or macrosomia were compared to children born with a normal birthweight, children with DQ8/X were less likely to have been born with macrosomia and children with DQX/X were more likely to have been born with a low birthweight compared to those with DQ2/8. This result remained after adjustment for maternal age (Table 11).

Table 11 ORs for being born with a low birthweight or macrosomia, compared to a normal birthweight, depending on genotype.

\begin{tabular}{ccccc}
\hline & \multicolumn{2}{c}{ Low birthweight $<\mathbf{2 , 5 0 0} \mathbf{g}$} & \multicolumn{2}{c}{ Macrosomia $\geq \mathbf{4 , 0 0 0} \mathbf{g}$} \\
\hline & $\begin{array}{l}\text { Crude OR } \\
(95 \% \mathrm{CI})\end{array}$ & $\begin{array}{l}\text { Adjusted OR } \\
(95 \% \mathrm{CI})\end{array}$ & $\begin{array}{l}\text { Crude OR } \\
(95 \% \mathrm{CI})\end{array}$ & $\begin{array}{l}\text { Adjusted OR } \\
(95 \% \mathrm{CI})\end{array}$ \\
\hline Genotype & & & & \\
DQ2/8 & Reference & Reference & Reference & Reference \\
$\mathrm{DQ} 8 / \mathrm{X}$ & $1.03(0.65-1.69)$ & $1.03(0.65-1.64)$ & $\mathbf{0 . 8 4}(\mathbf{0 . 7 1 - 0 . 9 9 )})$ & $\mathbf{0 . 8 4}(\mathbf{0 . 7 1 - 0 . 9 9 )}$ \\
DQ2/X & $1.21(0.69-2.14)$ & $1.24(0.70-2.19)$ & $0.83(0.66-1.03)$ & $0.83(0.66-1.03)$ \\
DQX/X & $\mathbf{2 . 1 0}(\mathbf{1 . 2 9 - 3 . 6 9 )})$ & $\mathbf{2 . 1 5}(\mathbf{1 . 2 2 - 3 . 7 8})$ & $0.99(0.77-1.27)$ & $0.99(0.77-1.27)$ \\
\hline Maternal age & & & - & reference \\
13-29 years & - & reference & - & $1.05(0.91-1.21)$ \\
$\geq 30$ years & - & $1.31(0.91-1.89)$ & &
\end{tabular}

Adjusted OR includes maternal age.

\section{OTHER NEONATAL CHARACTERISTICS}

\section{Gestational age/pregnancy length}

There was no difference in pregnancy length between children with T1D and control children (Tables 4 and 6) in the smaller study population of study II. In study III, a slight difference in distribution of gestational age between children with and without T1D was seen $(\mathrm{p}=0.014)$, with more children who later developed T1D having been born moderately preterm $(5.4 \% \mathrm{vs}$ $4.9 \%$, Table 9). In the unadjusted regression analysis, being born moderately preterm increased the risk of T1D (crude OR 1.11 [95\% CI 1.01 - 1.23]) and being born very preterm seemed to decrease the risk (crude OR 0.69 [95\% CI $0.50-0.95]$ ). However, these significances disappeared in the adjusted model (Table 7).

There was no difference in gestational age between the HLA genotype groups among children with T1D (Table 8).

\section{AGE AT ONSET OF T1D}

Maternal BMI was inversely associated with age at onset of T1D $(\mathrm{p}<0.001)$ among the 3,231 children with T1D included in study II. There was no obvious impact on children diagnosed at 
age 10-14 but in children diagnosed at a younger age (0-4 years and 5-9 years) there was a clear tendency of increasing incidence of T1D with higher maternal BMI and for children diagnosed in the oldest age group (15-19 years) the pattern was reversed (Figure 9). The results were the same for boys and girls but could only be observed in children whose mothers did not have diabetes.

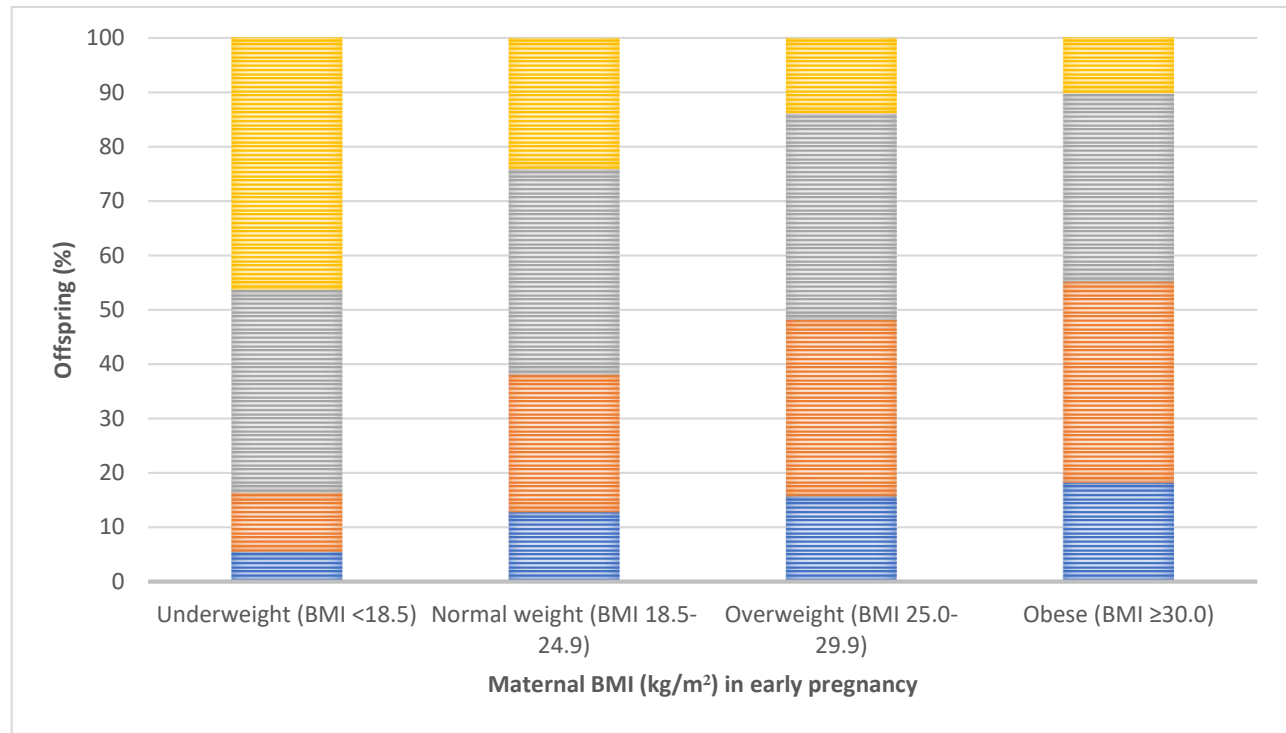

Figure 9 Maternal BMI in early pregnancy in relation to child's age at onset of T1D $(n=3,231)$. Age of child: blue bars, 0-4 years; orange bars, 5-9 years; light gray bars, 10-14 years; yellow bars, 15-19 years $(p<0.001)$.

The proportion of children with T1D $(n=9,278)$, regardless of sex, with a birthweight $<2,500$ $\mathrm{g}$ increased with age at diagnosis of T1D and the proportion with a normal birthweight decreased $(\mathrm{p}=0.039)$. In the youngest age group, $2 \%$ had a low birthweight and $77.8 \%$ a normal birthweight. This increased/decreased stepwise to $4 \%$ with a low and $74.6 \%$ with a normal birthweight in the oldest age group. No effect on age at onset of T1D was seen by size for gestational age $(\mathrm{p}=0.073)$.

Among children with T1D, regardless of sex, the age at onset of T1D was significantly different between the HLA genotype groups $(\mathrm{p}<0.001)$. A higher proportion of children with DQ2/8 were diagnosed at a younger age, and for children with DQX/X the opposite association was found (Table 8).

The results of study IV supported an impact of maternal BMI on age at onset of T1D. However, the effect was not seen in children without one of the two high risk haplotypes, i.e., in those with DQX/X. For children with DQ8/X ( $<<0.001)$ and DQ2/X $(\mathrm{p}=0.002)$ maternal 
BMI increased with younger age at onset (when treated as a continuous variable). The same pattern, though not significant ( $\mathrm{p}=0.139$ ) was seen in those with DQ2/8 (Figure 10). Stratified analysis (Table 12), with age at onset divided into four age categories as in studies II and III, also found an effect of maternal BMI. Compared to an age at onset of 15-18 years, maternal overweight and obesity increased the risk of being diagnosed in all three younger age groups for children with DQ2/X. For children with DQ2/8 the risk was increased for the ages 5-9 and 10-14 and for those with DQ8/X at age 0-4 and 5-9. Again, no effect was seen in children with DQX/X.

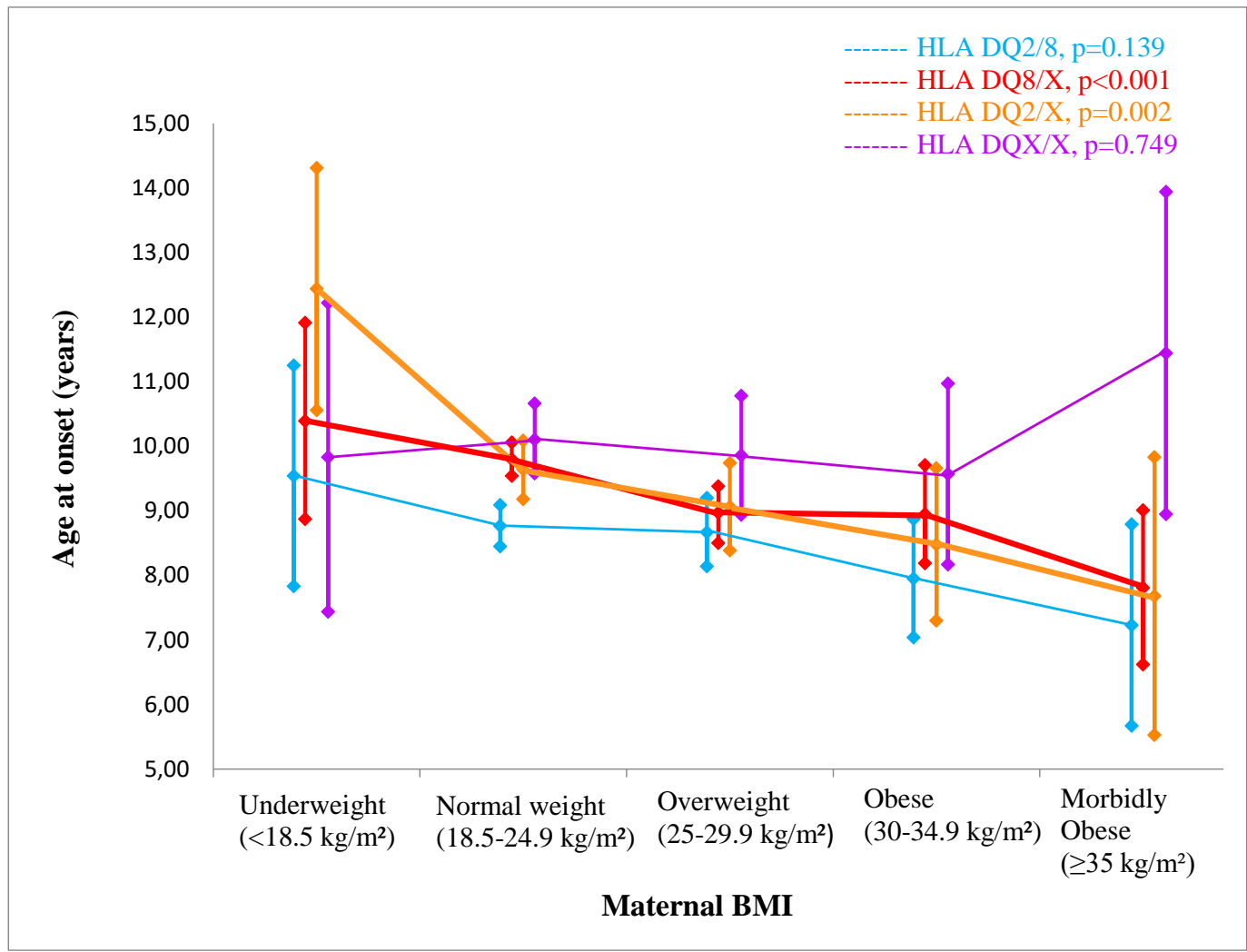

Figure 10 Age at onset of T1D depending on the child's genotype and maternal BMI

There was no significant effect of a high birthweight on age at onset of T1D in either analysis. In the stratified analysis, a low birthweight and to be born SGA showed a decreased risk for children with DQX/X of being diagnosed with T1D at the age 10-14, compared to 15-18 years, but no other significant effects were observed. To be born LGA, on the other hand, seemed to increase the risk for children with DQ8/X of being diagnosed when aged 0-4 years compared to $15-18$ years (Table 12). 
Table 12 Stratified multinomial regression analysis, by genotype, with ORs for age at onset of T1D depending on birthweight, size for gestational age or maternal BMI.

\begin{tabular}{|c|c|c|c|c|c|}
\hline \multirow[b]{2}{*}{ Outcome } & & \multicolumn{4}{|c|}{ Group according to genotype } \\
\hline & & DQ2/8 & DQ8/X & DQ2/X & $\mathrm{DQX} / \mathrm{X}$ \\
\hline & & OR $(95 \% \mathrm{CI})$ & OR $(95 \% \mathrm{CI})$ & OR $(95 \% \mathrm{CI})$ & OR $(95 \% \mathrm{CI})$ \\
\hline \multicolumn{6}{|c|}{ Age at onset* } \\
\hline \multirow[t]{11}{*}{$0-4$ years } & Birthweight** & & & & \\
\hline & $<2,500 \mathrm{~g}$ & $0.38(0.12-1.21)$ & $0.88(0.28-2.75)$ & $0.54(0.11-2.53)$ & $0.29(0.06-1.42)$ \\
\hline & $2,500-3,999 \mathrm{~g}$ & Reference & Reference & Reference & Reference \\
\hline & $\geq 4,000 \mathrm{~g}$ & $0.66(0.41-1.04)$ & $0.74(0.50-1.10)$ & $0.99(0.52-1.89)$ & $0.53(0.23-1.26)$ \\
\hline & Maternal BMI *: & & & & \\
\hline & $<25 \mathrm{~kg} / \mathrm{m}^{2}$ & Reference & Reference & Reference & Reference \\
\hline & $\geq 25 \mathrm{~kg} / \mathrm{m}^{2}$ & $1.52(0.91-2.54)$ & $2.20(1.47-3.29)$ & $2.33(1.21-4.47)$ & $0.82(0.35-1.93)$ \\
\hline & Size for age ${ }^{* *}$ & & & & \\
\hline & SGA & $0.60(0.18-2.03)$ & $0.62(0.12-3.24)$ & $2.70(0.50-14.51)$ & $0.72(0.14-3.80)$ \\
\hline & AGA & Reference & Reference & Reference & Reference \\
\hline & LGA & $0.69(0.28-1.70)$ & $2.43(1.16-5.07)$ & $1.00(0.20-5.14)$ & NA \\
\hline \multirow[t]{11}{*}{ 5-9 years } & Birthweight*** & & & & \\
\hline & $<2,500 \mathrm{~g}$ & $0.41(0.15-1.13)$ & $1.19(0.50-2.82)$ & $0.78(0.22-2.77)$ & $0.41(0.14-1.17)$ \\
\hline & $2,500-3,999 \mathrm{~g}$ & Reference & Reference & Reference & Reference \\
\hline & $\geq 4,000 \mathrm{~g}$ & $0.94(0.63-1.40)$ & $0.77(0.56-1.06)$ & $0.97(0.55-1.70)$ & $0.83(0.45-1.53)$ \\
\hline & Maternal BMI *: & & & & \\
\hline & $<25 \mathrm{~kg} / \mathrm{m}^{2}$ & Reference & Reference & Reference & Reference \\
\hline & $\geq 25 \mathrm{~kg} / \mathrm{m}^{2}$ & $1.94(1.20-3.14)$ & $1.57(1.10-2.24)$ & $3.00(1.65-5.44)$ & $1.31(0.68-2.54)$ \\
\hline & Size for age $* *$ & & & & \\
\hline & SGA & $0.30(0.08-1.07)$ & $1.27(0.43-3.76)$ & $2.47(0.51-11.92)$ & $0.45(0.11-1.88)$ \\
\hline & AGA & Reference & Reference & Reference & Reference \\
\hline & LGA & $0.89(0.41-1.95)$ & $1.78(0.91-3.48)$ & $2.74(0.77-9.81)$ & $1.52(0.44-5.24)$ \\
\hline \multirow[t]{11}{*}{ 10-14 years } & Birthweight $^{* * * *}$ & & & & \\
\hline & $<2,500 \mathrm{~g}$ & $0.44(0.17-1.18)$ & $1.24(0.53-2.86)$ & $0.68(0.19-2.41)$ & $0.12(0.03-0.45)$ \\
\hline & $2,500-3,999 \mathrm{~g}$ & Reference & Reference & Reference & Reference \\
\hline & $\geq 4,000 \mathrm{~g}$ & $1.06(0.71-1.57)$ & $0.93(0.69-1.26)$ & $1.14(0.67-1.94)$ & $0.58(0.33-1.03)$ \\
\hline & Maternal BMI *: & & & & \\
\hline & $<25 \mathrm{~kg} / \mathrm{m}^{2}$ & Reference & Reference & Reference & Reference \\
\hline & $\geq 25 \mathrm{~kg} / \mathrm{m}^{2}$ & $1.73(1.07-2.79)$ & 1.39 (0.98-1.99) & $2.15(1.19-3.86)$ & $0.89(0.48-1.68)$ \\
\hline & Size for age $* *$ & & & & \\
\hline & SGA & $0.34(0.10-1.12)$ & $1.51(0.54-4.22)$ & $0.68(0.11-4.15)$ & $0.18(0.04-0.92)$ \\
\hline & AGA & Reference & Reference & Reference & Reference \\
\hline & LGA & $1.07(0.51-2.26)$ & $1.76(0.91-3.40)$ & $1.62(0.44-5.92)$ & $0.85(0.24-3.00)$ \\
\hline
\end{tabular}

* 15-19 years of age at onset is defined as the reference category.

** Adjusted for maternal age at childbirth 


\section{DISCUSSION}

MAIN FINDINGS

Study I

\begin{tabular}{|l|c|}
\hline \hline Hypothesis & Accepted or rejected \\
\hline To be born by CS increases the risk of T1D & Rejected \\
\hline
\end{tabular}

In univariate analyses there were more children with T1D who had been born by CS. However, when adjusting for maternal diabetes, age and BMI, the increased risk with CS disappeared. Mothers with diabetes gave birth by CS substantially more often than women without diabetes, but among mothers with diabetes there was no significant difference in mode of childbirth between the index and control children. Moreover, mothers without diabetes had the same proportion of children who developed T1D, regardless of mode of childbirth. Maternal diabetes was the strongest predictor of T1D in the offspring, especially maternal T1D.

\section{Study II}

\begin{tabular}{|l|c|}
\hline \hline Hypothesis & Accepted or rejected \\
\hline $\begin{array}{l}\text { A higher maternal BMI and a greater GWG } \\
\text { increase the risk of T1D in the offspring. }\end{array}$ & Partly accepted \\
\hline
\end{tabular}

Maternal obesity increased the risk of T1D in the offspring even after adjustment for confounding factors. Maternal BMI was also inversely associated with the age at onset of T1D in the offspring, with more obese mothers among children diagnosed at the age 0-4 years and more underweight women among children diagnosed at the age 15-19. In addition, the results from study III revealed an increased risk of T1D in the offspring with maternal overweight. Yet GWG had no obvious impact on the risk of T1D in the offspring.

\section{Study III}

\begin{tabular}{|l|c|}
\hline \hline Hypothesis & Accepted or rejected \\
\hline To be born either LGA or SGA affects the risk, & Accepted \\
independently of maternal BMI and diabetes, of later \\
developing T1D.
\end{tabular}

To be born LGA was associated with an increased risk of T1D while to be born SGA was associated with a decreased risk. These results were the same regardless of sex and 
irrespective of maternal diabetes and BMI. They were also the same when comparing only children born at term and when using the broader definition of LGA/SGA. In addition, more children with T1D had been born with macrosomia and fewer with a low birthweight.

\section{Study IV}

\begin{tabular}{|l|c|}
\hline \hline Hypothesis & Accepted or rejected \\
\hline $\begin{array}{l}\text { Children who have developed T1D, with an HLA } \\
\text { genotype with lower genetic susceptibility, are more } \\
\text { often born LGA, with a high birthweight and/or to } \\
\text { mothers with a high BMI compared to children who } \\
\text { have developed T1D with the highest risk HLA } \\
\text { genotype. }\end{array}$ & Partly rejected \\
\hline $\begin{array}{l}\text { Birthweight, size for gestational age and maternal BMI } \\
\text { affect the age at onset of T1D differently depending on } \\
\text { the HLA genotype of the child. }\end{array}$ & Partly accepted \\
\hline
\end{tabular}

Birthweight was slightly different between the HLA genotype groups. Children with the highest genetic risk (DQ2/8) were more often born with macrosomia compared to children with DQ8/X. Children without either DQ2 or DQ8 (DQX/X) were more often born with a low birthweight compared to those with DQ2/8 and DQ8/X. Neither size for gestational age nor maternal BMI differed between the HLA genotype groups. Maternal overweight and obesity was associated with an increased risk for children within all HLA genotype groups, except DQX/X, of being diagnosed with T1D before age 15 (compared to age 15-18). However, the effect of size for gestational age and birthweight on age at onset of T1D was less clear.

\section{INTERPRETATION OF FINDINGS AND RELATION TO OTHER STUDIES}

\section{Mode of childbirth}

The finding from study I that CS does not increase the risk of T1D is in line with several previous studies ${ }^{91,92,103-107}$. In addition, the crude OR is close to the adjusted OR found in a meta-analysis ${ }^{102}$, as well as a Swedish cohort study ${ }^{101}$, that found an increased risk with CS. The latter's sibling design, however, indicated that their result was due to familial confounding rather than a causative role of CS, which could explain our different results. Studies regarding CS as a risk factor for T1D have also been performed after study I, confirming the result. A Danish cohort study from $2016^{202}$ with 1,760,366 children, of whom 4,400 children had developed T1D, found an increased risk of T1D in children born with prelabor CS compared to vaginal birth; however, when adjusted for maternal T1D the increased 
risk disappeared. Also, an Australian study that investigated vaginal birth, pre-labor CS and intrapartum CS, found no difference in risk of T1D. The authors concluded that perhaps the difference in microbiota from mode of childbirth is not important in T1D development ${ }^{99}$. However, microbiota can be influenced in other ways, for example through $\operatorname{diet}^{113}$, and may therefore still be important in the etiology of T1D.

\section{Maternal BMI and GWG}

Studies I-III revealed that maternal overweight and obesity were associated with an increased risk of T1D in the offspring, but GWG was not. These results are consistent with a more recently published large cohort study from Norway and Denmark ${ }^{203}$, as well as a metaanalysis from $2019^{204}$, which included study II, and a meta-analysis of cohort studies from $2021^{149}$. The two meta-analyses did not investigate GWG. Nonetheless, previous studies on GWG, except one on children at high genetic risk of T1D ${ }^{140}$, have also failed to see an association with offspring T1D ${ }^{104,139,141}$. When examining women with and without diabetes in study II, we could only find the association between maternal obesity and offspring T1D in mothers without diabetes. This result is in accordance with a large Swedish cohort study that found an increased risk of T1D in the offspring with maternal obesity in women without diabetes, but no effect of maternal BMI in women with T1D or GDM, and even a decreased risk when analyzing all women with diabetes ${ }^{107}$. Since a high maternal BMI seems to be a rather weak risk factor for T1D, it is possible that the effect is too small to be noticeable if the mother has diabetes. Maternal diabetes was the strongest risk factor identified in studies I-III, especially maternal T1D, and it may be that the genetic risk imposed on their offspring outweighs the additional risk of a high maternal BMI. In line with that, a study on children with a high genetic risk of T1D ${ }^{141}$ found no increased risk of T1D with maternal BMI, CS or birthweight. However, it may also be that, as the number of mothers with diabetes was substantially smaller than the number of mothers without diabetes in the studies, the lack of a positive association is because power was too low.

As discussed in the background, intrauterine mechanisms have been proposed as an explanation for the association between maternal BMI and offspring T1D. However, the cohort study from Norway and Denmark ${ }^{203}$ also found an increased risk of offspring T1D with paternal BMI, in the same magnitude as maternal BMI, implying that it might not be the intrauterine environment that is of importance but rather genetic or other environmental factors. Further studies are needed to clarify if a high maternal BMI during pregnancy is causative or a marker for other factors. 
A high maternal BMI was also associated with an earlier age at onset of T1D, at least in children with either DQ2 and/or DQ8. Whether this is connected to an intrauterine mechanism or other factors in the child's environment after birth, for which maternal BMI is a marker, remains to be established.

\section{Maternal smoking}

A surprising result from studies II and III was that maternal smoking was associated with a reduced risk of T1D in the offspring. This result is, nonetheless, in line with other epidemiological studies ${ }^{205}$, and a meta-analysis from $2019^{204}$ that found a reduced RR of T1D with maternal smoking close to the OR in study III. However, a Swedish case-control study that took HLA genotype into consideration instead showed an increased risk of T1D if the mother had smoked during pregnancy regardless of the HLA haplotype. The prevalence of smoking was almost doubled in cases compared to controls ${ }^{206}$. Yet we found no difference in the proportion of maternal smoking between children with T1D and different genotypes in study IV.

Since mothers who smoke during pregnancy also very likely do so after pregnancy, one question is whether it is smoking during pregnancy that is a risk. One study has compared maternal smoking prior, during and after pregnancy and paternal smoking, and found a decreased risk of T1D only with maternal smoking during pregnancy ${ }^{207}$. How smoking could affect the risk of T1D is largely unknown, but smoking has been shown to affect both the innate and adaptive immune system and has both pro- and anti-inflammatory properties ${ }^{208}$. In addition, smoking has been implicated as a risk factor for some autoimmune diseases (for example rheumatoid arthritis, Crohn's disease and $\mathrm{SLE}^{209}$ ) and is believed to be protective against others (for example ulcerous colitis and sarcoidosis ${ }^{56}$ ). Cigarette smoke consists of more than 4,000 different components, of which nicotine is one of the primary ${ }^{56}$ and it readily crosses the placenta ${ }^{210}$. Nicotine has been shown to exert anti-inflammatory effects on activated immune cells through the nicotine acetylcholine receptors (nAChRs), which can be found on for example T- and B-cells and macrophages ${ }^{56}$. The anti-inflammatory role of $\alpha 7$ $\mathrm{nAChR}$ has been suggested in $\alpha 7$ knockout mice ${ }^{211}$. The first experiment with T1D mice, where mice were injected with nicotine, showed a decrease in Th1- and an increase in Th2cytokines in pancreatic tissue and a decreased incidence of T1D in the mice ${ }^{56}$. A study in rats showed that nicotine-treated rats had a reduced body weight, lower blood insulin levels and improved insulin sensitivity, the latter at least in part via the $\alpha 7 \mathrm{nAChR}^{212}$. Yet smoking is known to have many deleterious effects on both mother and fetus and can never be 
recommended because of this. In addition, maternal smoking may be a confounder to some other variable that affects the risk of T1D.

\section{Size for gestational age and birthweight}

Study III showed that more children who developed T1D had been born LGA and/or with macrosomia (birthweight $\geq 4,000 \mathrm{~g}$ ). This result is in line with several previous studies ${ }^{105,160-164}$ though not all of them have found the association with both LGA and macrosomia. Studies that have found no relationship between birthweight or size for gestational age and T1D have all been smaller than study III $^{36,92,106,107,134,136}$.

Study III also showed that fewer children who developed T1D were born SGA or with a low birthweight. This is also consistent with previous studies ${ }^{91,105,162}$, though the evidence is more ambiguous. The mechanism is also less clear for this association. Most of the explanatory hypothesis, described in the background, instead predicts an increased risk of T1D also for these children. But explanations could be less active $\beta$-cells, as children born SGA have been shown to have increased insulin sensitivity at birth ${ }^{213}$, or a changed immune system, as low birthweight neonates have been shown to have defects in their adaptive immune system ${ }^{156}$. In addition, the association has some support in animal models, as NOD mice were protected from autoimmune diabetes by in utero undernutrition that reduced the insulitis and $\beta$-cell apoptosis in their pancreas ${ }^{156}$. Yet it cannot be ruled out that some other underlying mechanism is the cause of the reduced risk, and SGA/low birthweight is merely a marker of that. Almost contradictory to this result, study IV showed that children who had developed T1D despite not having either DQ2 or DQ8 (DQX/X) were more often born with a low birthweight compared to those with either DQ2/8 or DQ8/X. This latter result is in line with the DoHaD hypothesis, and it could be speculated that to be born with a low birthweight reduces the risk of T1D for individuals with genetic risk of T1D, but rather the opposite for those without genetic risk. This will of course need to be tested in additional studies.

The results from study IV indicates that children with T1D and the DQ2/8 genotype were more often born with macrosomia compared to children with DQ8/X. In addition, DQ2/8 has been shown to be connected to a higher birthweight in the general population ${ }^{184}$. Therefore, the increased risk of T1D with macrosomia may be due to a shared genetic risk rather than birthweight per se. Neither study found a connection between LGA and HLA genotype, and as discussed in the background, the two reflect partly different populations, as a child can be LGA but not have a birthweight $>4,000 \mathrm{~g}$ and vice versa. 
Study IV also showed that to be born LGA increased the risk for children with DQ8/X of being diagnosed with T1D early in life. This is in line with the hypothesis that LGA could be an accelerant, yet the result needs to be verified in a larger study as it was not consistent in all analyses and the CI was rather large. The results of study IV also indicated that to be born SGA or with a low birthweight were associated with a decreased risk for children with DQX/X of being diagnosed at the age of 10-14 compared to later. However, very few children were born SGA and with a low birthweight within the DQX/X genotype (13 and 22, respectively) and the results should therefore be interpreted with caution.

As discussed in the background there are several theories for how birthweight or maternal BMI might be connected to risk of T1D. It might be an intrauterine effect, but it may also be what happens after birth. A high birthweight has been shown to be an independent risk factor for childhood obesity at age 7 , independent of maternal and paternal obesity and maternal education. Parental obesity was, however, a much stronger risk factor ${ }^{133}$. Both a higher growth rate in childhood ${ }^{168}$ and childhood obesity have been associated with increased risk of $\mathrm{T}_{1} \mathrm{D}^{165}$. Obesity leads to a low-grade inflammation in the body $\mathrm{y}^{214}$ and an association between inflammation and autoimmunity was suggested as early as $1964^{215}$. Obesity has been associated with increased risk of autoimmune diseases, including psoriasis, multiple sclerosis, and rheumatoid arthritis, as well as a worsening of the course of some autoimmune diseases. The adipose tissue is an endocrine organ that secretes several adipokines (cytokines), among the most important being leptin, adiponectin, visfatin and resistin. Most of their actions are pro-inflammatory and they contribute to the low-grade inflammation in obese subjects. Leptin is upregulated in obese subjects and leads to the release of pro-inflammatory cytokines, like TNF- $\alpha$, and a reduction of Tregs in the adipose tissue, leading to enhanced local inflammation. Adiponectin, instead, promotes anti-inflammatory cytokines, but is decreased in the serum of overweight patients. Cytokines shown to be increased by these adipokines have also been shown to be involved in T1D pathogenesis ${ }^{214,216}$.

\section{METHODOLOGICAL CONSIDERATIONS}

The scientific evidence from a study can be discussed in terms of internal and external validity. The studies included in this thesis are observational, and in observational studies there is always some kind of problem with internal validity. Therefore, the question of causality can never be answered by this study design. However, for some research questions RCTs are not possible to perform. Longitudinal prospective cohort studies are time- 
consuming and costly and the usage of previously collected material from registers, though it has inherent problems, is an alternative way in which scientific evidence can be gathered.

The internal validity is how reliable the result of the study is, i.e., how confident one can be that the exposure variable truly influences the outcome. The external validity is how generalizable the result of a study is to other populations and settings. There is always a tradeoff between internal and external validity. The more you control and restrict your study population the less generalizability you get. However, good internal validity is also necessary for external validity ${ }^{217}$. In the sections below the two terms will be discussed in relation to the studies included in this thesis.

\section{Internal validity}

The internal validity is affected by random errors (chance) and systemic errors (bias). A random error (sampling error) is the risk that the result of a study by chance does not reflect the whole population. The study populations in studies I-IV were collected by convenience sampling. However, a large study size, like the ones in these studies, reduces the risk of random errors, as the risk of by chance selecting only individuals with a certain trait lessens. The risk of a random error, if there is no systemic error, can be expressed by statistical significance, either a p-value or a CI. A large CI indicates a larger risk of random error and vice versa ${ }^{217}$. One problem with a very large sample size, however, will be the risk of statistically significant but clinically irrelevant results. For example, study I revealed that the difference between mothers of cases and mothers of controls in mean BMI is small and maybe clinically irrelevant as such. However, the result that maternal obesity is associated with increased risk of T1D in the offspring (studies II and III) is not related to mean BMI in the groups and is therefore more clinically relevant.

Systemic errors, however, are not affected by study size and are of three different types:

1. Selection bias, i.e., collecting a sample that is not representative of the population you want to analyze. For the studies in this thesis, the original study population consisted of all children diagnosed with T1D during a 12-year period and four matched controls, making such error less likely. However, study II only included individuals with information on maternal diabetes, GWG, BMI, parity and pregnancy length; therefore, selection bias could be an issue in this study. However, the missing case analysis revealed no large differences, and the results from study II were in accordance with those from studies I and III which used the whole population. Study IV also included almost every child diagnosed with T1D during the period 
in which the BDD study has been ongoing, which in the same way lessens the risk of selection bias.

2. Information bias can be divided into reporting bias, recall bias, misclassification bias, and observer bias, i.e., systematic differences from the truth which makes the information used in the study incorrect. Handling of missing data can also cause information bias.

The registers used in this thesis, as well as the BDD study, have very good coverage, i.e., less risk of reporting bias. All material is prospectively collected into the registers and the BDD study and is therefore free from recall bias. However, some of the material in the registers is self-reported and this could bias study results. Maternal BMI in early pregnancy is calculated from self-reported height, and weight was sometimes measured and sometimes self-reported. This could result in misclassification bias. However, since individuals tend to overreport their height and underreport their weight ${ }^{218}$, the potential bias would probably underestimate the increased risks associated with maternal obesity. Previous studies have also shown that selfreported $\mathrm{BMI}$ is reliable in research ${ }^{219}$. Another self-reported variable used in our studies is maternal smoking. A Swedish study comparing cotinine levels in maternal serum, cord-blood, and self-reported smoking habits in the MBR found that there was a high agreement and concluded that the MBR can be considered a valid measure for maternal smoking ${ }^{220}$. In addition, with register data there is also a risk of misclassification caused by incorrect registration. Nevertheless, if present it is random and not systematic.

With register data there is also the problem of missing data. Since the national registers are not part of a study, but of clinical routine, all data is not always collected for every patient. Reasons for this could for example be a patient's wishes, conditions in the work environment or that it is simply forgotten. This could cause reporting bias, but again this would more likely be random than systematic. In the MBR the coverage for variables like pregnancy duration, birthweight and length is good. Mode of childbirth also has a good coverage, though the differentiation between acute and planned CS among preterm children is not as good. Data on mothers' weight in early pregnancy (at the first antenatal-care visit), weight increase, weight at childbirth, and height have been compiled since 1983. Practically no data are available between 1990 and 1991 for weight in early pregnancy and between 1990 and 1993 for weight at delivery. Height is known for about $80 \%$ of the mothers, weight in early pregnancy for around $70 \%$ and weight at delivery has a good coverage before 1990 but only $33-43 \%$ after 1993. It is possible to calculate BMI for about $65 \%$ of women with a reasonable accuracy ${ }^{196}$. This means that in study II for example there are almost no children born between 1990 and 
1993 in the study population. However, it also means that cases with information are more likely to be matched.

In studies III and IV children with missing data on either birthweight or pregnancy length were assumed to be AGA. Assuming a value for a part of the population could of course influence the result. However, as this variable was assumed in only $0.3 \%$ of children it is unlikely to have any affect. In addition, sensitivity analyses were carried out in studies III and IV (excluding children assumed to be AGA) and these analyses yielded the same results as when children assumed to be AGA were included.

3. Confounding leads to the suggestion that there is an association where none actually exists or to the failure to see an association though there is one. There are a few ways to control for confounding (i.e., increase internal validity) when collecting the data: randomization, restriction, and matching ${ }^{221}$. Randomization is not possible when studying T1D etiology. We matched our index children with controls that had the same sex and were born on the same day and in the same region in Sweden. This was done in order to minimize confounding by sex, age group and environmental factors depending on region and season. In studies II-IV we also restricted our study population to singletons.

However, there is always a risk for confounding in observational studies, as the groups are not randomized (even if they are matched and restricted). Statistical methods, such as logistic regression, can be used to account for confounding ${ }^{221}$. Still, there is always the risk of additional confounders that are not addressed in the study.

Confounders are variables that affect both the exposure and the outcome (Figure 11). They are not to be confused with other factors, like intermediates, colliders, and covariates, for which adjustments should not be made. Though the theoretical picture is easy to understand, the relationship between variables is in reality not always that uncomplicated, and deciding which variable is a confounder is sometimes quite complex. Confounders can be chosen in different ways: by using clinical knowledge, previous studies or by considering statistical differences between groups in the data. All these methods have been used in studies I-IV, but in study IV we only adjusted for the confounder we found in our material as previous studies on the subject are scarce.

The MBR allows for adjustment of multiple confounders, but there are of course additional variables which could confound the results, of which we unfortunately had no information. The most important are paternal BMI and diabetes, socioeconomic factors, ethnicity, exercise 


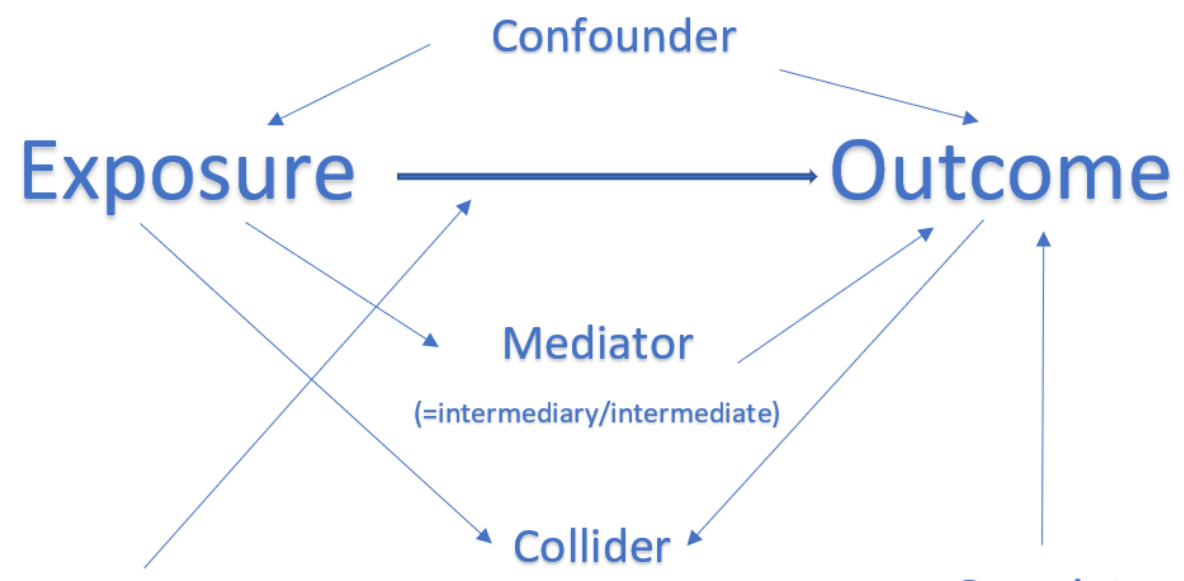

Moderator

\section{Covariate}

Figure 11 Theoretical picture of the relationship between exposure and outcome as well as other variables.

Other limitations include the risk of multiple comparison (type 1) error, i.e., a false positive. With a significance level (p-value) of 0.05 there is a $5 \%$ risk that a found association is not true. However, when testing the same hypothesis more than one time with the same data set, the risk for type I error increases (multiples) so that when 20 tests have been performed one will be false positive. A way to minimize the risk, and keep the significance level at 0.05 , is to adjust the p-value when doing multiple comparisons. This was done in study IV when analyzing birthweight. However, no such adjustment was done in study II when examining GWG, so though a significant difference (p-value=0.04) in the risk of offspring T1D was found in underweight mothers with inadequate GWG compared to those with adequate or excessive GWG, there is a greater than 5\% risk of this being false. However, since adjusted analysis showed no effect of GWG on risk of T1D, the conclusion of the study was not affected by this.

\section{External validity}

The study population in the studies of this thesis includes all children and adolescents, from all over Sweden, diagnosed with T1D over a period of 12 years, and this makes the results generalizable to Sweden. However, since genetics differ between countries and ethnic groups, it is more difficult to ensure that the results are generalizable to other countries and ethnic 
groups. Most likely, though, they are generalizable to countries comparable to Sweden. In other populations the knowledge gained from this thesis can be used in designing new studies.

\section{CONCLUDING REMARKS}

For some of the findings, especially those from study IV, it is hard to compare results between studies as the definition of investigated environmental factors has varied, for example macrosomia $\geq 4,000 \mathrm{~g}$ or $\geq 4,500 \mathrm{~g}$, and the classification of genetic risk has been different. Also, to date not that many studies have been conducted. Yet it is important to try to elucidate if certain environmental risk factors are more important for individuals with a high or a low genetic susceptibility.

One problem with research regarding the etiology of T1D is that many of the environmental risk factors that have been implicated confound each other, for example a high maternal BMI gives a greater risk of a high birthweight and a greater risk of CS. Both a higher maternal BMI and a high birthweight give a greater risk of a higher weight in infancy, diet influences weight and weight gain etc. The list can go on almost indefinitely. Therefore, it may be that the environmental risk factors identified in this thesis will later turn out to be confounders to other risk factors.

One way to further evaluate the environmental risk factors is to conduct prospective cohort studies that collect information regarding all known risk factors and related variables. Since the incidence of T1D in the general population is quite low the cohort needs to be very large to have enough power to evaluate weak risk factors. In for example the ABIS study, which included 16,387 children born in Sweden between 1997 and 1999, only 137 children had developed T1D as of November $2017^{90}$. In order to have more children with T1D, though in a smaller body of material, many prospective cohort studies are conducted on children at high genetic risk of T1D. However, some risk factors may be more important in those without a high genetic risk, as maternal BMI only seems to increase the risk of offspring T1D in mothers without diabetes and may therefore not be identified in such cohort studies. In addition, even in large studies with children at high genetic risk the number of children developing T1D will be rather small. This could lead to power being too low to detect risk factors of a smaller magnitude. The question then is - is it important to find these factors if they convey only such a small increase in risk? Well, if the risk factor is very common in the general population, such as overweight and obesity, it may still lead to a substantial number of cases of T1D. Furthermore, the factors are important to identify in order to understand the pathogenesis of T1D better. 


\section{CONCLUSION}

\section{GENERAL CONCLUSION}

The etiology of T1D is extremely complex and heterogeneous. Some of the environmental factors investigated in this thesis are associated with $\mathrm{T} 1 \mathrm{D}$, but the question remains of whether they are causative. Also, their individual contribution to the risk of disease is small and the greatest risk factor identified in this thesis is maternal diabetes.

Nonetheless, maternal overweight and obesity is common, and a risk factor for other healthrelated problems. BMI and birthweight are also, at least partly, modifiable. These factors, taken together, motivate additional research regarding their involvement in T1D etiology as well as preventive actions against overweight and obesity in the population.

\section{SPECIFIC CONCLUSIONS}

* To be born by CS was not associated with an increased risk of T1D, but to have a mother with diabetes greatly increased the risk of being born by CS.

Maternal diabetes was the strongest risk factor for T1D in the offspring of all environmental factors investigated in studies I-III.

* Maternal overweight and obesity in early pregnancy, in women without diabetes, increased the risk of T1D in the offspring. Yet it was not more common to have had a mother with a high BMI among children who had developed T1D, in spite of a lowrisk genotype, compared to children who had developed T1D with a high-risk genotype.

* Maternal overweight and obesity was associated with an earlier age at onset of T1D, but this effect was only seen in children with a genotype containing either DQ2 or DQ8, or both.

GWG had no obvious impact on the risk of T1D in the offspring.

* To be born LGA increased the risk and to be born SGA decreased the risk of T1D, irrespective of maternal diabetes and BMI. Still, among children with T1D, size for gestational age did not differ depending on genotype.

* Further studies are needed to elucidate if birthweight is different depending on genotype or is related to risk of T1D, and whether birthweight and size for gestational age affect the age at onset of T1D in children with a certain genetic risk. 


\section{FUTURE PERSPECTIVES}

* To investigate the connection between environmental risk factors and specific genotypes in a larger body of material and with a more precise genotype classification.

* To compare children with and without T1D with respect to their HLA genotype and birthweight.

* To investigate autoantibodies in children who develop T1D in relation to environmental risk factors such as maternal overweight/obesity or being born LGA/with macrosomia.

* To explore maternal smoking as a risk factor for T1D in a study that can account for other factors such as socioeconomic status, ethnicity, diet etc. and to investigate different components of cigarette smoke to elucidate which, if any, influence T1D pathogenesis.

To conduct a study investigating women with diabetes compared to women without diabetes and the risk of T1D in their offspring depending on maternal BMI and the child's size for gestational age.

* To study whether maternal BMI is a risk factor for, and affects the age at onset of, T1D when accounting for other factors in the child's environment. 


\section{POPULÄRVETENSKAPLIG SAMMANFATTNING}

Typ 1 diabetes (T1D) är en autoimmun sjukdom där kroppens eget immunsystem angriper de insulinproducerande cellerna i bukspottkörteln så att de förstörs. Detta gör att insulinet, som krävs för att kroppens celler ska kunna ta upp socker (näring), inte kan produceras. Personer som drabbas av T1D kan därför inte tillgodogöra sig näring från maten. Sjukdomsprocessen startar långt innan man får symtom och diagnostiseras med T1D. De flesta insjuknar som barn och ungdomar men även vuxna kan drabbas.

I början av 1900-talet var T1D en ovanlig sjukdom och innan insulinet upptäcktes år 1921 dog den som drabbades snabbt. Trots betydande utveckling i behandlingen av T1D riskerar den som drabbas än idag att få allvarliga komplikationer som njursvikt, blindhet, amputation av fot/underben och hjärtkärlsjukdom. Som grupp har de som drabbats av T1D också en förkortad livslängd. Antalet personer som insjuknar med T1D har ökat sedan mitten på 1900talet och de senaste årtiondena har ökningen varit mycket snabb.

T1D kan drabba alla människor men är vanligare hos de som har en släkting med sjukdomen. Genetiska faktorer spelar roll för utvecklingen och ungefär 50\% av den genetiska risken beror på HLA (från engelskans human leukocyte antigen) genotypen. En genotyp bildas av två haplotyper (samling av specifika gener). Man ärver en haplotyp från sin mamma och en från sin pappa. Starkast koppling finns till HLA-DR och -DQ, som är tätt kopplade till varandra och tillsammans kodar för HLA molekylen som finns på celler i vårt immunsystem. Vilken HLA-DR-DQ-genotyp man har påverkar vilka proteiner från bakterier, virus och skadade celler i kroppen, som immunsystemet kan reagera på. De haplotyper som ger högst risk för T1D är HLA-DR3-DQ2 och HLA-DR4-DQ8. Allra högst risk har man om man har en genotyp med båda dessa haplotyper (DQ2/8). I Sverige har 90\% av barn och ungdomar som insjuknar i T1D en eller båda haplotyperna. På senare år har man dock sett att andelen som insjuknar med den högsta riskgenotypen har minskat och andelen som har genotyper med lägre risk har ökat. En studie har också visat att hos de som hade genotypen DQ2/2 så var det fler barn som var överviktiga.

Utöver genetiska faktorer spelar miljöfaktorer en viktig roll för utvecklingen av T1D och man tror att det är miljöfaktorerna som har orsakat den snabba ökningen av antalet T1D fall (eftersom genetiken inte kan ändras så snabbt). Många olika miljöfaktorer, som infektioner, olika dieter, fysisk och psykisk stress, övervikt och snabb tillväxt, har undersökts som riskfaktorer för T1D, men resultaten av studierna har ofta pekat åt olika håll. Det är dessutom 
oklart om vissa faktorer kan medverka till att starta den autoimmun processen och andra istället driva på processen. Dessutom blir det alltmer uppenbart att en viss miljöfaktor kanske är viktig hos individer men en viss genetisk risk för T1D, men kanske inte är så viktig hos personer med annan genetisk risk. Eftersom barn kan insjukna i ung ålder och sjukdomsprocessen kan starta långt innan diagnosen ställs, samt att ökningen av fall hos barn under 5 år har varit mycket stor, så är det intresserat att undersöka miljöfaktorer kopplade till graviditet och nyföddhetsperioden och om dessa kan öka risken för T1D. Även här har tidigare studier visat motstridiga resultat.

Under samma tidsperiod som T1D ökat, har också flera andra faktorer i samhället ökat. Bland dessa finns andelen barn som föds med kejsarsnitt, andelen barn som föds med hög födelsevikt eller är tunga för tiden samt övervikt och fetma (högt kroppsmasseindex [BMI]), både hos barn och vuxna.

\section{Målet med avhandlingen}

Det övergripande syftet med den här avhandlingen var att undersöka riskfaktorer runt graviditet och förlossning för att se om de skulle kunna öka eller minska risken för att barn och ungdomar utvecklar T1D. I den första studien undersöktes om risken för T1D påverkades av förlossningssättet. I den andra om mammans BMI eller viktuppgång under graviditeten hade någon betydelse och i den tredje studerades om barnets födelsevikt i relation till graviditetslängd hade någon betydelse för risken att utveckla T1D. I den sista delstudien undersöktes om de riskfaktorer som identifierats hade olika hög förekomst beroende på om barnen som utvecklat T1D hade hög- eller låg genetisk risk för sjukdomen.

\section{Hur gjordes studierna?}

Studiepopulationen bestod av 9376 barn och ungdomar som diagnostiserats med T1D mellan 1982 och 2011 och som fanns registrerade i det svenska barndiabetesregistret (SWEDIABKIDS). Till dessa barn kopplades en kontrollgrupp från det svenska medicinska födelseregistret (MFR) med barn utan diabetes, men med samma kön och som var födda samma dag och år och i samma del av Sverige (totalt 37504 individer). Från MFR hämtades också information av intresse för studierna kring förlossningssätt och uppgifter om barnen och deras mödrar. Till den sista studien (delstudie IV) användes också information om barnens genotyp från den svenska Bättre Diabetes Diagnostik (BDD) studien. Resultaten i avhandlingen bygger på tre fall-kontrollstudier (delstudie I-III) och en kohortstudie, dvs studie på en grupp individer avseende en/flera exponeringar, i detta fall barn med T1D 
(delstudie IV). I den första delstudien användes hela studiepopulationen och i delstudie III alla utom de individer som var tvillingar (552 individer). I den andra delstudien användes endast den del av studiepopulationen för vilka det fanns information i MFR om mammans BMI och viktuppgång under graviditeten (3 231 barn med T1D och 12948 kontrollbarn). I den sista delstudien inkluderades de barn med T1D som också var registrerade i BDD studien, totalt 4 533 barn.

\section{Vad visade studierna?}

Jämfört med kontrollbarnen, var det fler barn med T1D som hade en mamma som varit överviktig eller som haft fetma tidigt i graviditeten. Proportionen av mödrar med högt respektive lågt BMI skilde sig också åt beroende på i vilket åldersspann som barnen/ungdomarna insjuknat i T1D. Det var vanligare att barn som insjuknat med T1D i ung ålder (under 10 år) hade en mamma som varit överviktig eller som haft fetma under graviditeten medan de som insjuknade mellan 15-19 år oftare hade en mamma som varit underviktig under graviditeten. I den sista delstudien, då riskfaktorernas förekomst bland barn med olika genetisk risk jämfördes, var det inte vanligare att barn som trots låg genetisk risk utvecklat T1D hade en mamma som haft ett högt BMI. Däremot såg man att det var hos barn med HLA-DQ2 och/eller HLA-DQ8 som övervikt och fetma hos modern var associerat med att insjukna i T1D innan 15 års ålder, medan det hos de som inte hade någon av de två riskhaplotyperna (kallade DQX/X) inte fanns någon skillnad i insjuknandeålder beroende på moderns BMI.

Hur stor viktuppgång mamman haft under graviditeten verkade inte vara en faktor som påverkade risken för barnet att insjukna i T1D. Det var inte heller fler barn med T1D som hade fötts med kejsarsnitt. Däremot var det mycket vanligare för barn med T1D att ha en mamma med diabetes och det var vanligt att mammor med diabetes fött barn med kejsarsnitt. Det var mindre vanligt att barn med T1D hade en mamma som rökt under graviditeten.

Barn med T1D hade i större utsträckning fötts stora för tiden eller med en hög födelsevikt (mer än 4000 gram) och i mindre utsträckning fötts små för tiden eller med en låg födelsevikt (under 2500 gram), oavsett om deras mammor hade varit normal- eller överviktiga eller om mamman haft diabetes under graviditeten. När barnen med T1D delades in beroende på genotyp var det ingen skillnad i andelen barn som hade fötts stora eller små för tiden men födelsevikten skilde sig något åt mellan grupperna. Barn som inte hade någon av de två riskhaplotyperna (DQX/X) hade oftare fötts med en låg födelsevikt jämfört med både de som hade den högsta genetiska risken (DQ2/8) och de med hög genetisk risk (DQ8/X). Barn med 
den högsta genetiska risken hade också oftare fötts med en hög födelsevikt jämfört de med DQ8/X.

\section{Vad kan man dra för slutsatser av resultaten?}

I denna avhandling är de miljöfaktorer som visade sig vara associerade med ökad risk för T1D övervikt och fetma hos modern under graviditet och att vara född stor för tiden eller med en hög födelsevikt. Moderns övervikt och fetma skulle också kunna leda till ett tidigare insjuknande i T1D hos barn med genetisk risk för sjukdomen. Trots att den typen av studier som avhandlingen bygger på aldrig kan ge svar på orsakssamband är stora studier med prospektivt insamlat material, som i denna avhandling, ett av de bästa sätten vi har för att komma närmre svaret på varför vissa personer utvecklar T1D.

Generellt gav de identifierade riskfaktorerna endast en marginell ökning av risken för T1D, men med tanke på att dessa faktorer är vanliga i populationen så ger även en liten riskökning stor påverkan på antalet nyinsjuknande i T1D. T1D är en allvarlig, kronisk sjukdom som inte bara påverkar barnet/ungdomen som drabbas, utan också hela dennes familj. Varje fall som kan förhindras är därmed en stor vinst. Med tanke på att övervikt, fetma och hög födelsevikt också visat sig vara kopplade till flera andra negativa hälsoeffekter/risker, och att dessa faktorer åtminstone delvis kan påverkas genom olika insatser, är det viktigt att både fortsätta utforska deras potentiella betydelse för risken att utveckla T1D samt att arbeta med preventiva åtgärder för att minska dessa riskfaktorers förekomst i populationen. 


\section{ACKNOWLEDGEMENT}

I would like to thank each and everyone who has supported and encouraged me, not only during my time as a $\mathrm{PhD}$ student, but also before that. Without all of you I would never have been able to complete this! In particular I would like to thank:

My main supervisor Professor Ulf Samuelsson, for always being supportive and helpful, kind and encouraging. Thank you for letting me grow during this process, for helping me and for giving me a little nudge when I needed that! Your guidance in the world of science has been utmost important to me!

My co-supervisor Professor Ann Josefsson - without you I would never have begun this journey. Thank you for thinking of me for this project and encouraging me to become a $\mathrm{PhD}$ student. Thank you for your quick responses, organized mind, and positive attitude!

My co-supervisor Professor Annelie Carlsson for reminding me not to forget to live in the meantime. Thank you for your hospitality when I was in Skåne and for taking me to my first research conference in Toronto. Thank you for the weekend-work and late-night phone calls over study IV!

Marie Bladh for not only giving invaluable help with statistics but also for always having the time to listen and give advice no matter the subject. Thank you for working on your vacation and for your encouraging words. Your friendship throughout this journey has truly been fantastic!

Associate Professor Karin Åkesson for interesting conversations and constructive criticism on manuscripts.

The participants in the E4:an group, for your useful input on papers and presentations.

The members of the $\boldsymbol{B D D}$ group for valuable insights and lessons regarding research. I have learned so much from writing together with you!

Qefsere Brahimi, Agnes Andersson Svärd, Rasmus Bennet, Ida Jönsson and Alexander Lind for taking such good care of me at the lab in Malmö.

My fellow PhD-students for interesting discussions and group works during PhD-courses. Associate Professor Helena Fadl and Professor Peter Bang for your many valuable comments on my half-time seminar. 
Professor Marie Blomberg, Associate Professor Caroline Lilliecreutz, Dr Hartmut Vogt, Dr Elham Dadfar, Professor Preben Kjölhede and Senior Professor Johnny Ludvigsson for taking the time to review my manuscripts and thesis and contributing with valuable reflections.

Professor Markus Heilig for once up on a time when I was a medical student, allowing me to come to his lab at NIAAA and for introducing me to the world of research in the best way possible. I don't think I would have considered becoming a PhD-student had you not been so enthusiastic and encouraging!

Associate Professor Ninnie Borendahl Wodlin, Dr Annika Jeppsson, Associate Professor Elizabeth Nedstrand and Dr Sofia Pihl for allowing me time for research and encouraging words of wisdom along the way.

My fantastic colleagues at the department of Obstetrics and Gynecology in Linköping. You always encourage and have kind words. Thank you for making work so much better and for doing the clinical work while I wrote this thesis. I am so grateful for all of you!

My parents, Björn and Ditte, for letting me use their home as an office away from the office and a home away from home. Thank you for you encouraging words and you never ending belief in me, for raising me to be who I am today. Thank you, mum, for always proofreading everything I write, including this thesis. Thank you, dad, for being my party-planner. I love you both!

My wonderful brothers $\boldsymbol{O l o f}$ and $\boldsymbol{O}$ scar, and my sister-in-law Sanne, for support and neverending love! Thank you for playing with my kids so I could complete this thesis and thank you for being my toastmasters! I love you!

My mother-in-law Annike and my father-in law Björn for opening their home and hearts to me and for taking care of my children when I work.

My sisters- and brothers-in-law, Maria, Joakim, Anders, Anna, Erik, and Sandra, thank you for support and friendship. You all mean so much to me!

My grandfather Carl-Eric, for always encouraging and being part of my life. I miss you every single day! I know you would have wanted to be here today.

My mother Ditte and mother-in-law Annike for taking care of Gustav so I was able to finish this thesis. I don't think I could have done it without you! 
My dear friends Johanna and Anna for persuading me to go to Washington DC as a medical student. Without you I would never have known that research was fun! I am so thankful for our friendship!

My friends Amanda and David for letting med stay with them during my visits to the lab in Malmö and for nice dinners and conversations!

My dear friend Annika - what would I do without you?! Your friendship and support mean so much to me! Thank you for the surprise celebration after my half-time seminar and for all your valuable support both during the process of finishing this thesis but also in life in general!

My friend Marina for always supporting me. Thank you for spending time with me and the kids and making life just that much better!

All my friends for their encouragement and support! I appreciate each and everyone of you so much!

Last, but definitely not least, thank you my wonderful husband Johan and our precious kids August, Olivia and Gustav, without you none of this matter! Johan, you are the love of my life. Thank you for your support, for taking care of our kids and putting up with all my research work, I know it was not always easy. Thank you for sharing your life with me, encouraging me, and standing by my side! My wonderful children, thank you for being the light of my life! I love you more than words can say!

August, Olivia och Gustav - ni är de finaste barnen man kan tänka sig och jag älskar er så mycket! Nästa sommar lovar jag att jag inte ska arbeta någonting! 
1. Mayer-Davis EJ, Kahkoska AR, Jefferies C, et al., ISPAD Clinical Practice Consensus Guidelines 2018: Definition, epidemiology, and classification of diabetes in children and adolescents. Pediatr Diabetes 2018;19 Suppl 27:7-19.

2. Tuomilehto J. The emerging global epidemic of type 1 diabetes. Curr Diab Rep 2013;13:795-804.

3. The Swedish Pediatric Diabetes Quality Register . Annual report 2020. Available from https://www.ndr.nu/\#/blanketter. Retrieved July 6, 2021.

4. Ryden L, Lindsten J. The history of the Nobel prize for the discovery of insulin. Diabetes Res Clin Pract 2021;175:108819.

5. Abbas AK, Lichtman, A.H., Pillai, S. Cellular and molecular immunology, ninth edition. Elsevier; 2018.

6. Noble JA, Valdes AM. Genetics of the HLA region in the prediction of type 1 diabetes. Curr Diab Rep 2011;11:533-42.

7. Regnell SE, Lernmark A. Early prediction of autoimmune (type 1) diabetes. Diabetologia 2017;60:1370-81.

8. Smith DA, Germolec DR. Introduction to immunology and autoimmunity. Environ Health Perspect 1999;107 Suppl 5:661-5.

9. Ahmed R, Omidian Z, Giwa A, et al. A Public BCR Present in a Unique Dual-Receptor-Expressing Lymphocyte from Type 1 Diabetes Patients Encodes a Potent T Cell Autoantigen. Cell 2019;177:158399 e16.

10. Mosmann TR, Sad S. The expanding universe of T-cell subsets: Th1, Th2 and more. Immunol Today 1996;17:138-46.

11. Rautajoki KJ, Kylaniemi MK, Raghav SK, Rao K, Lahesmaa R. An insight into molecular mechanisms of human T helper cell differentiation. Ann Med 2008;40:322-35.

12. Walker LS, Abbas AK. The enemy within: keeping self-reactive $T$ cells at bay in the periphery. Nat Rev Immunol 2002;2:11-9.

13. Zhang P, Lu Q. Genetic and epigenetic influences on the loss of tolerance in autoimmunity. Cell Mol Immunol 2018;15:575-85.

14. Marrack P, Kappler J, Kotzin BL. Autoimmune disease: why and where it occurs. Nat Med 2001;7:899905.

15. Erlich H, Valdes AM, Noble J, et al. HLA DR-DQ haplotypes and genotypes and type 1 diabetes risk: analysis of the type 1 diabetes genetics consortium families. Diabetes 2008;57:1084-92.

16. van Belle TL, Coppieters KT, von Herrath MG. Type 1 diabetes: etiology, immunology, and therapeutic strategies. Physiol Rev 2011;91:79-118.

17. Krischer JP, Lynch KF, Schatz DA, et al. The 6 year incidence of diabetes-associated autoantibodies in genetically at-risk children: the TEDDY study. Diabetologia 2015;58:980-7.

18. Ilonen J, Hammais A, Laine AP, et al. Patterns of beta-cell autoantibody appearance and genetic associations during the first years of life. Diabetes 2013;62:3636-40.

19. American Diabetes A. 2. Classification and Diagnosis of Diabetes: Standards of Medical Care in Diabetes-2021. Diabetes Care 2021;44:S15-S33.

20. Gale EA. The rise of childhood type 1 diabetes in the 20th century. Diabetes 2002;51:3353-61.

21. Persson M, Becker C, Elding Larsson H, et al. The Better Diabetes Diagnosis (BDD) study - A review of a nationwide prospective cohort study in Sweden. Diabetes Res Clin Pract 2018;140:236-44.

22. Nathan DM, Cleary PA, Backlund JY, et al. Intensive diabetes treatment and cardiovascular disease in patients with type 1 diabetes. N Engl J Med 2005;353:2643-53.

23. Diabetes C, Complications Trial Research G, Nathan DM, et al. The effect of intensive treatment of diabetes on the development and progression of long-term complications in insulin-dependent diabetes mellitus. N Engl J Med 1993;329:977-86.

24. Bojestig M, Arnqvist HJ, Hermansson G, Karlberg BE, Ludvigsson J. Declining incidence of nephropathy in insulin-dependent diabetes mellitus. N Engl J Med 1994;330:15-8.

25. Lind M, Pivodic A, Svensson AM, Olafsdottir AF, Wedel H, Ludvigsson J. HbAlc level as a risk factor for retinopathy and nephropathy in children and adults with type 1 diabetes: Swedish population based cohort study. BMJ 2019;366:14894.

26. Nordwall M, Abrahamsson M, Dhir M, Fredrikson M, Ludvigsson J, Arnqvist HJ. Impact of HbA1c, followed from onset of type 1 diabetes, on the development of severe retinopathy and nephropathy: the VISS Study (Vascular Diabetic Complications in Southeast Sweden). Diabetes Care 2015;38:308-15.

27. Samuelsson J, Samuelsson U, Hanberger L, Bladh M, Akesson K. Poor metabolic control in childhood strongly correlates to diabetes-related premature death in persons $<30$ years of age-A population-based cohort study. Pediatr Diabetes 2020;21:479-85. 
28. Rawshani A, Sattar N, Franzen S, et al. Excess mortality and cardiovascular disease in young adults with type 1 diabetes in relation to age at onset: a nationwide, register-based cohort study. Lancet 2018;392:477-86.

29. Lind M, Svensson AM, Kosiborod M, et al. Glycemic control and excess mortality in type 1 diabetes. N Engl J Med 2014;371:1972-82.

30. Subramanian S, Baidal D. The Management of Type 1 Diabetes. In: Feingold KR, Anawalt B, Boyce A, et al., eds. Endotext. South Dartmouth (MA)2000.

31. Lord $\mathrm{S}$, Greenbaum CJ. Insulin is necessary but not sufficient: changing the therapeutic paradigm in type 1 diabetes. F1000Res 2020;9.

32. Keymeulen B, Vandemeulebroucke E, Ziegler AG, et al. Insulin needs after CD3-antibody therapy in new-onset type 1 diabetes. N Engl J Med 2005;352:2598-608.

33. Herold KC, Bundy BN, Long SA, et al. An Anti-CD3 Antibody, Teplizumab, in Relatives at Risk for Type 1 Diabetes. N Engl J Med 2019;381:603-13.

34. Knip M. Type 1 diabetes in Finland: past, present, and future. Lancet Diabetes Endocrinol 2021;9:25960.

35. Tuomilehto J, Ogle GD, Lund-Blix NA, Stene LC. Update on Worldwide Trends in Occurrence of Childhood Type 1 Diabetes in 2020. Pediatr Endocrinol Rev 2020;17:198-209.

36. Patterson CC, Harjutsalo V, Rosenbauer J, et al. Trends and cyclical variation in the incidence of childhood type 1 diabetes in 26 European centres in the 25 year period 1989-2013: a multicentre prospective registration study. Diabetologia 2019;62:408-17.

37. Berhan Y, Waernbaum I, Lind T, Mollsten A, Dahlquist G, Swedish Childhood Diabetes Study G. Thirty years of prospective nationwide incidence of childhood type 1 diabetes: the accelerating increase by time tends to level off in Sweden. Diabetes 2011;60:577-81.

38. The Swedish Pediatric Diabetes Quality Register . Annual report 2013. Available from https://www.ndr.nu/\#/blanketter. Retrieved Sep 27.

39. Harjutsalo V, Sund R, Knip M, Groop PH. Incidence of type 1 diabetes in Finland. JAMA 2013;310:427-8.

40. Parviainen A, But A, Siljander H, Knip M, Finnish Pediatric Diabetes R. Decreased Incidence of Type 1 Diabetes in Young Finnish Children. Diabetes Care 2020;43:2953-8.

41. Skrivarhaug T, Stene LC, Drivvoll AK, Strom H, Joner G, Norwegian Childhood Diabetes Study G. Incidence of type 1 diabetes in Norway among children aged 0-14 years between 1989 and 2012: has the incidence stopped rising? Results from the Norwegian Childhood Diabetes Registry. Diabetologia 2014;57:57-62.

42. Flint SA, Gunn AJ, Hofman PL, et al. Evidence of a plateau in the incidence of type 1 diabetes in children 0-4 years of age from a regional pediatric diabetes center; Auckland, New Zealand: 1977-2019. Pediatr Diabetes 2021.

43. Haynes A, Bulsara MK, Bergman P, et al. Incidence of type 1 diabetes in 0 to 14 year olds in Australia from 2002 to 2017. Pediatr Diabetes 2020;21:707-12.

44. Harvey JN, Hibbs R, Maguire MJ, O'Connell H, Gregory JW, Brecon G. The changing incidence of childhood-onset type 1 diabetes in Wales: Effect of gender and season at diagnosis and birth. Diabetes Res Clin Pract 2021;175:108739.

45. Craig ME, Jefferies C, Dabelea D, et al. ISPAD Clinical Practice Consensus Guidelines 2014. Definition, epidemiology, and classification of diabetes in children and adolescents. Pediatric diabetes 2014;15 Suppl 20:4-17.

46. Hussen HI, Persson M, Moradi T. The trends and the risk of type 1 diabetes over the past 40 years: an analysis by birth cohorts and by parental migration background in Sweden. BMJ open 2013;3:e003418.

47. Group DP. Incidence and trends of childhood Type 1 diabetes worldwide 1990-1999. Diabetic medicine : a journal of the British Diabetic Association 2006;23:857-66.

48. Fox DA, Islam N, Sutherland J, Reimer K, Amed S. Type 1 diabetes incidence and prevalence trends in a cohort of Canadian children and youth. Pediatric diabetes 2017.

49. Fazeli Farsani S, Souverein PC, van der Vorst MM, et al. Increasing trends in the incidence and prevalence rates of type 1 diabetes among children and adolescents in the Netherlands. Pediatric diabetes 2016;17:44-52.

50. Atkinson MA. The pathogenesis and natural history of type 1 diabetes. Cold Spring Harb Perspect Med 2012;2.

51. Phillips JM, Parish NM, Raine T, et al. Type 1 diabetes development requires both CD4+ and CD8+ T cells and can be reversed by non-depleting antibodies targeting both $\mathrm{T}$ cell populations. Rev Diabet Stud 2009;6:97-103. 
52. Insel RA, Dunne JL, Atkinson MA, et al. Staging presymptomatic type 1 diabetes: a scientific statement of JDRF, the Endocrine Society, and the American Diabetes Association. Diabetes Care 2015;38:196474.

53. Bloem SJ, Roep BO. The elusive role of B lymphocytes and islet autoantibodies in (human) type 1 diabetes. Diabetologia 2017;60:1185-9.

54. Ziegler AG, Rewers M, Simell O, et al. Seroconversion to multiple islet autoantibodies and risk of progression to diabetes in children. JAMA 2013;309:2473-9.

55. Delli AJ, Lindblad B, Carlsson A, et al. Type 1 diabetes patients born to immigrants to Sweden increase their native diabetes risk and differ from Swedish patients in HLA types and islet autoantibodies. Pediatr Diabetes 2010;11:513-20.

56. Gomes JP, Watad A, Shoenfeld Y. Nicotine and autoimmunity: The lotus' flower in tobacco. Pharmacol Res 2018;128:101-9.

57. Marroqui L, Dos Santos RS, Op de Beeck A, et al. Interferon-alpha mediates human beta cell HLA class I overexpression, endoplasmic reticulum stress and apoptosis, three hallmarks of early human type 1 diabetes. Diabetologia 2017;60:656-67.

58. Gepts W. Pathologic anatomy of the pancreas in juvenile diabetes mellitus. Diabetes 1965;14:619-33.

59. Campbell-Thompson M, Fu A, Kaddis JS, et al. Insulitis and beta-Cell Mass in the Natural History of Type 1 Diabetes. Diabetes 2016;65:719-31.

60. Lehuen A, Diana J, Zaccone P, Cooke A. Immune cell crosstalk in type 1 diabetes. Nat Rev Immunol 2010;10:501-13.

61. Kallionpaa H, Elo LL, Laajala E, et al. Innate immune activity is detected prior to seroconversion in children with HLA-conferred type 1 diabetes susceptibility. Diabetes 2014;63:2402-14.

62. Aad G, Abajyan T, Abbott B, et al. Search for magnetic monopoles in sqrt $[\mathrm{s}]=7 \mathrm{TeV}$ pp collisions with the ATLAS detector. Phys Rev Lett 2012;109:261803.

63. Krogvold L, Wiberg A, Edwin B, et al. Insulitis and characterisation of infiltrating $\mathrm{T}$ cells in surgical pancreatic tail resections from patients at onset of type 1 diabetes. Diabetologia 2016;59:492-501.

64. Klinke DJ, 2nd. Extent of beta cell destruction is important but insufficient to predict the onset of type 1 diabetes mellitus. PLoS One 2008;3:e1374.

65. Sanjeevi CB, Sedimbi SK, Landin-Olsson M, et al. Risk conferred by HLA-DR and DQ for type 1 diabetes in 0-35-year age group in Sweden. Ann N Y Acad Sci 2008;1150:106-11.

66. Olmos P, A'Hern R, Heaton DA, et al. The significance of the concordance rate for type 1 (insulindependent) diabetes in identical twins. Diabetologia 1988;31:747-50.

67. Kaprio J, Tuomilehto J, Koskenvuo M, et al. Concordance for type 1 (insulin-dependent) and type 2 (non-insulin-dependent) diabetes mellitus in a population-based cohort of twins in Finland. Diabetologia 1992;35:1060-7.

68. Redondo MJ, Jeffrey J, Fain PR, Eisenbarth GS, Orban T. Concordance for islet autoimmunity among monozygotic twins. N Engl J Med 2008;359:2849-50.

69. Redondo MJ, Steck AK, Pugliese A. Genetics of type 1 diabetes. Pediatric diabetes 2017.

70. Nerup J, Platz P, Andersen OO, et al. HL-A antigens and diabetes mellitus. Lancet 1974;2:864-6.

71. Sanjeevi CB, Lybrand TP, DeWeese C, et al. Polymorphic amino acid variations in HLA-DQ are associated with systematic physical property changes and occurrence of IDDM. Members of the Swedish Childhood Diabetes Study. Diabetes 1995;44:125-31.

72. Pociot F, Lernmark A. Genetic risk factors for type 1 diabetes. Lancet 2016;387:2331-9.

73. Carlsson A, Kockum I, Lindblad B, et al. Low risk HLA-DQ and increased body mass index in newly diagnosed type 1 diabetes children in the Better Diabetes Diagnosis study in Sweden. Int J Obes (Lond) 2012;36:718-24.

74. Lambert AP, Gillespie KM, Thomson G, et al. Absolute risk of childhood-onset type 1 diabetes defined by human leukocyte antigen class II genotype: a population-based study in the United Kingdom. J Clin Endocrinol Metab 2004;89:4037-43.

75. Yang J, Lernmark A, Uusitalo UM, et al. Prevalence of obesity was related to HLA-DQ in 2-4-year-old children at genetic risk for type 1 diabetes. Int J Obes (Lond) 2014;38:1491-6.

76. Ilonen J, Sjoroos M, Knip M, et al. Estimation of genetic risk for type 1 diabetes. Am J Med Genet 2002;115:30-6.

77. Fourlanos S, Varney MD, Tait BD, et al. The rising incidence of type 1 diabetes is accounted for by cases with lower-risk human leukocyte antigen genotypes. Diabetes Care 2008;31:1546-9.

78. Peet A, Kool P, Ilonen J, Knip M, Tillmann V, Group DS. Birth weight in newborn infants with different diabetes-associated HLA genotypes in three neighbouring countries: Finland, Estonia and Russian Karelia. Diabetes Metab Res Rev 2012;28:455-61.

79. Motzo C, Contu D, Cordell HJ, et al. Heterogeneity in the magnitude of the insulin gene effect on HLA risk in type 1 diabetes. Diabetes 2004;53:3286-91. 
80. Noble JA, Valdes AM, Varney MD, et al. HLA class I and genetic susceptibility to type 1 diabetes: results from the Type 1 Diabetes Genetics Consortium. Diabetes 2010;59:2972-9.

81. Redondo MJ, Steck AK, Pugliese A. Genetics of type 1 diabetes. Pediatr Diabetes 2018;19:346-53.

82. Pugliese A, Miceli D. The insulin gene in diabetes. Diabetes Metab Res Rev 2002;18:13-25.

83. Durinovic-Bello I, Wu RP, Gersuk VH, Sanda S, Shilling HG, Nepom GT. Insulin gene VNTR genotype associates with frequency and phenotype of the autoimmune response to proinsulin. Genes Immun 2010;11:188-93.

84. Bjornvold M, Undlien DE, Joner G, et al. Joint effects of HLA, INS, PTPN22 and CTLA4 genes on the risk of type 1 diabetes. Diabetologia 2008;51:589-96.

85. Rewers M, Ludvigsson J. Environmental risk factors for type 1 diabetes. Lancet 2016;387:2340-8.

86. Oilinki T, Otonkoski T, Ilonen J, Knip M, Miettinen PJ. Prevalence and characteristics of diabetes among Somali children and adolescents living in Helsinki, Finland. Pediatr Diabetes 2012;13:176-80.

87. Stene LC, Oikarinen S, Hyoty H, et al. Enterovirus infection and progression from islet autoimmunity to type 1 diabetes: the Diabetes and Autoimmunity Study in the Young (DAISY). Diabetes 2010;59:3174-80.

88. Skyler JS. Primary and secondary prevention of Type 1 diabetes. Diabet Med 2013;30:161-9.

89. Ludvigsson J, Cuthbertson D, Becker DJ, et al. Increasing plasma glucose before the development of type 1 diabetes-the TRIGR study. Pediatr Diabetes 2021.

90. Belteky M, Wahlberg J, Ludvigsson J. Maternal respiratory infections in early pregnancy increases the risk of type 1 diabetes. Pediatr Diabetes 2020;21:1193-201.

91. Dahlquist GG, Patterson C, Soltesz G. Perinatal risk factors for childhood type 1 diabetes in Europe. The EURODIAB Substudy 2 Study Group. Diabetes Care 1999;22:1698-702.

92. Svensson J, Carstensen B, Mortensen HB, Borch-Johnsen K, Danish Study Group of Childhood D. Early childhood risk factors associated with type 1 diabetes--is gender important? Eur J Epidemiol 2005;20:429-34.

93. Stene LC, Gale EA. The prenatal environment and type 1 diabetes. Diabetologia 2013;56:1888-97.

94. Knip M, Veijola R, Virtanen SM, Hyoty H, Vaarala O, Akerblom HK. Environmental triggers and determinants of type 1 diabetes. Diabetes 2005;54 Suppl 2:S125-36.

95. Kulas T, Bursac D, Zegarac Z, Planinic-Rados G, Hrgovic Z. New Views on Cesarean Section, its Possible Complications and Long-Term Consequences for Children's Health. Med Arch 2013;67:460-3.

96. Martinez LD, Glynn LM, Sandman CA, Wing DA, Davis EP. Cesarean delivery and infant cortisol regulation. Psychoneuroendocrinology 2020;122:104862.

97. Betran AP, Merialdi M, Lauer JA, et al. Rates of caesarean section: analysis of global, regional and national estimates. Paediatr Perinat Epidemiol 2007;21:98-113.

98. Betran AP, Ye J, Moller AB, Souza JP, Zhang J. Trends and projections of caesarean section rates: global and regional estimates. BMJ Glob Health 2021;6.

99. Begum M, Pilkington R, Chittleborough C, Lynch J, Penno M, Smithers L. Caesarean section and risk of type 1 diabetes: whole-of-population study. Diabet Med 2019;36:1686-93.

100.Patterson CC, Carson DJ, Hadden DR, Waugh NR, Cole SK. A case-control investigation of perinatal risk factors for childhood IDDM in Northern Ireland and Scotland. Diabetes Care 1994;17:376-81.

101. Khashan AS, Kenny LC, Lundholm C, Kearney PM, Gong T, Almqvist C. Mode of obstetrical delivery and type 1 diabetes: a sibling design study. Pediatrics 2014;134:e806-13.

102. Cardwell CR, Stene LC, Joner G, et al. Caesarean section is associated with an increased risk of childhood-onset type 1 diabetes mellitus: a meta-analysis of observational studies. Diabetologia 2008;51:726-35.

103. Stene LC, Magnus P, Lie RT, Sovik O, Joner G, Norwegian Childhood Diabetes Study G. No association between preeclampsia or cesarean section and incidence of type 1 diabetes among children: a large, population-based cohort study. Pediatr Res 2003;54:487-90.

104. Dahlquist G, Kallen B. Maternal-child blood group incompatibility and other perinatal events increase the risk for early-onset type 1 (insulin-dependent) diabetes mellitus. Diabetologia 1992;35:671-5.

105. Algert CS, McElduff A, Morris JM, Roberts CL. Perinatal risk factors for early onset of Type 1 diabetes in a 2000-2005 birth cohort. Diabet Med 2009;26:1193-7.

106.Phillips J, Gill N, Sikdar K, Penney S, Newhook LA. History of cesarean section associated with childhood onset of T1DM in Newfoundland and Labrador, Canada. J Environ Public Health 2012;2012:635097.

107.Hussen HI, Persson M, Moradi T. Maternal overweight and obesity are associated with increased risk of type 1 diabetes in offspring of parents without diabetes regardless of ethnicity. Diabetologia 2015;58:1464-73.

108. Bach JF. Revisiting the Hygiene Hypothesis in the Context of Autoimmunity. Front Immunol 2020;11:615192. 
109.Sgrazzutti L, Sansone F, Attanasi M, Di Pillo S, Chiarelli F. Coaggregation of Asthma and Type 1 Diabetes in Children: A Narrative Review. Int J Mol Sci 2021;22.

110.Gale EA. A missing link in the hygiene hypothesis? Diabetologia 2002;45:588-94.

111.Kondrashova A, Viskari $H$, Kulmala $P$, et al. Signs of beta-cell autoimmunity in nondiabetic schoolchildren: a comparison between Russian Karelia with a low incidence of type 1 diabetes and Finland with a high incidence rate. Diabetes Care 2007;30:95-100.

112. Dahlen HG, Downe S, Wright ML, Kennedy HP, Taylor JY. Childbirth and consequent atopic disease: emerging evidence on epigenetic effects based on the hygiene and EPIIC hypotheses. BMC Pregnancy Childbirth 2016;16:4.

113.Tanaka M, Nakayama J. Development of the gut microbiota in infancy and its impact on health in later life. Allergol Int 2017;66:515-22.

114.Puff R, D'Orlando O, Heninger $A K$, et al. Compromised immune response in infants at risk for type 1 diabetes born by Caesarean Section. Clin Immunol 2015;160:282-5.

115. Stokholm J, Thorsen J, Chawes BL, et al. Cesarean section changes neonatal gut colonization. J Allergy Clin Immunol 2016;138:881-9 e2.

116.Dominguez-Bello MG, Costello EK, Contreras M, et al. Delivery mode shapes the acquisition and structure of the initial microbiota across multiple body habitats in newborns. Proc Natl Acad Sci U S A 2010;107:11971-5.

117. Salminen S, Gibson GR, McCartney AL, Isolauri E. Influence of mode of delivery on gut microbiota composition in seven year old children. Gut 2004;53:1388-9.

118. Davis-Richardson AG, Ardissone AN, Dias R, et al. Bacteroides dorei dominates gut microbiome prior to autoimmunity in Finnish children at high risk for type 1 diabetes. Front Microbiol 2014;5:678.

119.Lagercrantz H, Slotkin TA. The "stress" of being born. Sci Am 1986;254:100-7.

120. Ogden CL, Carroll MD, Kit BK, Flegal KM. Prevalence of childhood and adult obesity in the United States, 2011-2012. JAMA 2014;311:806-14.

121. Dudenhausen JW, Grunebaum A, Kirschner W. Prepregnancy body weight and gestational weight gainrecommendations and reality in the USA and in Germany. Am J Obstet Gynecol 2015;213:591-2.

122.Phillips JE, Couper JJ, Penno MAS, Harrison LC, Group ES. Type 1 diabetes: a disease of developmental origins. Pediatr Diabetes 2017;18:417-21.

123. Blomberg M. [Obesity during pregnancy increases the risk for both the woman and child. Skilled care can reduce the increased risk]. Lakartidningen 2015;112.

124. Haugen M, Brantsaeter AL, Winkvist A, et al. Associations of pre-pregnancy body mass index and gestational weight gain with pregnancy outcome and postpartum weight retention: a prospective observational cohort study. BMC Pregnancy Childbirth 2014;14:201.

125. Gaillard R, Durmus B, Hofman A, Mackenbach JP, Steegers EA, Jaddoe VW. Risk factors and outcomes of maternal obesity and excessive weight gain during pregnancy. Obesity (Silver Spring) 2013;21:1046-55.

126. Institute of Medicine (US) and National Research Council (US) Committee to Reexamine IOM Pregnancy Guidlines (2009) In: Rasmussen KM, Yaktine AL, eds. Weight Gain During Pregnancy: Reexamining the Guidelines. Washington (DC)2009.

127. Weir CB, Jan A. BMI Classification Percentile And Cut Off Points. StatPearls. Treasure Island (FL)2021.

128.Ugwuja EI, Nnabu RC, Ezeonu PO, Uro-Chukwu H. The effect of parity on maternal body mass index, plasma mineral element status and new-born anthropometrics. Afr Health Sci 2015;15:986-92.

129. Hashim M, Radwan $H$, Hasan $H$, et al. Gestational weight gain and gestational diabetes among Emirati and Arab women in the United Arab Emirates: results from the MISC cohort. BMC Pregnancy Childbirth 2019;19:463.

130.Lawlor DA. The Society for Social Medicine John Pemberton Lecture 2011. Developmental overnutrition--an old hypothesis with new importance? Int J Epidemiol 2013;42:7-29.

131. Dabelea D, Crume T. Maternal environment and the transgenerational cycle of obesity and diabetes. Diabetes 2011;60:1849-55.

132. Maftei O, Whitrow MJ, Davies MJ, Giles LC, Owens JA, Moore VM. Maternal body size prior to pregnancy, gestational diabetes and weight gain: associations with insulin resistance in children at 9-10 years. Diabet Med 2015;32:174-80.

133. Reilly JJ, Armstrong J, Dorosty AR, et al. Early life risk factors for obesity in childhood: cohort study. BMJ 2005;330:1357.

134.D'Angeli MA, Merzon E, Valbuena LF, Tirschwell D, Paris CA, Mueller BA. Environmental factors associated with childhood-onset type 1 diabetes mellitus: an exploration of the hygiene and overload hypotheses. Arch Pediatr Adolesc Med 2010;164:732-8. 
135. Robertson L, Harrild K. Maternal and neonatal risk factors for childhood type 1 diabetes: a matched case-control study. BMC Public Health 2010;10:281.

136.Jones ME, Swerdlow AJ, Gill LE, Goldacre MJ. Pre-natal and early life risk factors for childhood onset diabetes mellitus: a record linkage study. Int J Epidemiol 1998;27:444-9.

137.Lahti-Pulkkinen M, Bhattacharya S, Wild SH, et al. Consequences of being overweight or obese during pregnancy on diabetes in the offspring: a record linkage study in Aberdeen, Scotland. Diabetologia 2019;62:1412-9.

138. McKinney PA, Parslow R, Gurney K, Law G, Bodansky HJ, Williams DR. Antenatal risk factors for childhood diabetes mellitus; a case-control study of medical record data in Yorkshire, UK. Diabetologia 1997;40:933-9.

139.Vlajinac H, Sipetic S, Marinkovic J, Bjekic M, Kocev N, Sajic S. The Belgrade childhood diabetes study - comparison of children with type 1 diabetes with their siblings. Paediatr Perinat Epidemiol 2006;20:238-43.

140. Rasmussen T, Stene LC, Samuelsen SO, et al. Maternal BMI before pregnancy, maternal weight gain during pregnancy, and risk of persistent positivity for multiple diabetes-associated autoantibodies in children with the high-risk HLA genotype: the MIDIA study. Diabetes Care 2009;32:1904-6.

141. Arkkola T, Kautiainen S, Takkinen HM, et al. Relationship of maternal weight status and weight gain rate during pregnancy to the development of advanced beta cell autoimmunity in the offspring: a prospective birth cohort study. Pediatr Diabetes 2011;12:478-84.

142. Catalano PM, Presley L, Minium J, Hauguel-de Mouzon S. Fetuses of obese mothers develop insulin resistance in utero. Diabetes Care 2009;32:1076-80.

143.Barker DJ. The origins of the developmental origins theory. J Intern Med 2007;261:412-7.

144.Simmons R. Perinatal programming of obesity. Semin Perinatol 2008;32:371-4.

145.Plagemann A. A matter of insulin: developmental programming of body weight regulation. J Matern Fetal Neonatal Med 2008;21:143-8.

146. Aaen K, Rygaard J, Josefsen K, et al. Dependence of antigen expression on functional state of betacells. Diabetes 1990;39:697-701.

147.Purrello F, Buscema M, Rabuazzo AM, et al. Glucose modulates glucose transporter affinity, glucokinase activity, and secretory response in rat pancreatic beta-cells. Diabetes 1993;42:199-205.

148. Kampe O, Andersson A, Bjork E, Hallberg A, Karlsson FA. High-glucose stimulation of 64,000-Mr islet cell autoantigen expression. Diabetes 1989;38:1326-8.

149. Wang H, Zhang Z, Liu Y, et al. Pre-pregnancy body mass index in mothers, birth weight and the risk of type I diabetes in their offspring: A dose-response meta-analysis of cohort studies. J Gynecol Obstet Hum Reprod 2021;50:101921.

150. Collaboration NCDRF. Worldwide trends in body-mass index, underweight, overweight, and obesity from 1975 to 2016: a pooled analysis of 2416 population-based measurement studies in 128.9 million children, adolescents, and adults. Lancet 2017;390:2627-42.

151. Ghosh RE, Berild JD, Sterrantino AF, Toledano MB, Hansell AL. Birth weight trends in England and Wales (1986-2012): babies are getting heavier. Arch Dis Child Fetal Neonatal Ed 2018;103:F264-F70.

152. Oken E, Gillman MW. Fetal origins of obesity. Obesity research 2003;11:496-506.

153. Chiavaroli V, Castorani V, Guidone $P$, et al. Incidence of infants born small- and large-for-gestationalage in an Italian cohort over a 20-year period and associated risk factors. Ital J Pediatr 2016;42:42.

154.Akanmode AM, Mahdy H. Macrosomia. StatPearls. Treasure Island (FL) 2021.

155. World Health Organization. ICD-10: International statistical classification of diseases and related health problems, 10th revision. Volume 2. 2nd ed.Geneva: WHO; 2004. Available from: http://www.who.int/classifications/icd/ICD-10_2nd_ed_volume2.pdf. Retrieved August 1st 2021

156. Oge A, Isganaitis E, Jimenez-Chillaron J, et al. In utero undernutrition reduces diabetes incidence in non-obese diabetic mice. Diabetologia 2007;50:1099-108.

157. Society for Maternal-Fetal Medicine . Electronic address pso, Martins JG, Biggio JR, Abuhamad A. Society for Maternal-Fetal Medicine Consult Series \#52: Diagnosis and management of fetal growth restriction: (Replaces Clinical Guideline Number 3, April 2012). Am J Obstet Gynecol 2020;223:B2B17.

158. Oken E, Kleinman KP, Rich-Edwards J, Gillman MW. A nearly continuous measure of birth weight for gestational age using a United States national reference. BMC Pediatr 2003;3:6.

159. Marsal K, Persson PH, Larsen T, Lilja H, Selbing A, Sultan B. Intrauterine growth curves based on ultrasonically estimated foetal weights. Acta Paediatr 1996;85:843-8.

160. Dahlquist G, Bennich SS, Kallen B. Intrauterine growth pattern and risk of childhood onset insulin dependent (type I) diabetes: population based case-control study. BMJ 1996;313:1174-7. 
161. Cardwell CR, Carson DJ, Patterson CC. Parental age at delivery, birth order, birth weight and gestational age are associated with the risk of childhood Type 1 diabetes: a UK regional retrospective cohort study. Diabet Med 2005;22:200-6.

162. Goldacre RR. Associations between birthweight, gestational age at birth and subsequent type 1 diabetes in children under 12: a retrospective cohort study in England, 1998-2012. Diabetologia 2018;61:616-25.

163. Cardwell CR, Stene LC, Joner G, et al. Birthweight and the risk of childhood-onset type 1 diabetes: a meta-analysis of observational studies using individual patient data. Diabetologia 2010;53:641-51.

164. Harder T, Roepke K, Diller N, Stechling Y, Dudenhausen JW, Plagemann A. Birth weight, early weight gain, and subsequent risk of type 1 diabetes: systematic review and meta-analysis. Am J Epidemiol 2009;169:1428-36.

165. Nucci AM, Virtanen SM, Cuthbertson D, et al. Growth and development of islet autoimmunity and type 1 diabetes in children genetically at risk. Diabetologia 2021;64:826-35.

166. Hypponen E, Virtanen SM, Kenward MG, Knip M, Akerblom HK, Childhood Diabetes in Finland Study G. Obesity, increased linear growth, and risk of type 1 diabetes in children. Diabetes Care 2000;23:1755-60.

167.Larsson HE, Hansson G, Carlsson A, et al. Children developing type 1 diabetes before 6 years of age have increased linear growth independent of HLA genotypes. Diabetologia 2008;51:1623-30.

168. Johansson C, Samuelsson U, Ludvigsson J. A high weight gain early in life is associated with an increased risk of type 1 (insulin-dependent) diabetes mellitus. Diabetologia 1994;37:91-4.

169. Knerr I, Wolf J, Reinehr T, et al. The 'accelerator hypothesis': relationship between weight, height, body mass index and age at diagnosis in a large cohort of 9,248 German and Austrian children with type 1 diabetes mellitus. Diabetologia 2005;48:2501-4.

170. Khan N, Couper JJ. Low-birth-weight infants show earlier onset of IDDM. Diabetes Care 1994;17:6536.

171. Wilkin TJ. The accelerator hypothesis: weight gain as the missing link between Type I and Type II diabetes. Diabetologia 2001;44:914-22.

172. Dabelea D, D'Agostino RB, Jr., Mayer-Davis EJ, et al. Testing the accelerator hypothesis: body size, beta-cell function, and age at onset of type 1 (autoimmune) diabetes. Diabetes Care 2006;29:290-4.

173. Buzzetti R, Zampetti S, Pozzilli P. Impact of obesity on the increasing incidence of type 1 diabetes. Diabetes Obes Metab 2020;22:1009-13.

174. Buzzetti R, Spoletini M, Zampetti S, et al. Tyrosine phosphatase-related islet antigen 2(256-760) autoantibodies, the only marker of islet autoimmunity that increases by increasing the degree of BMI in obese subjects with type 2 diabetes. Diabetes Care 2015;38:513-20.

175. Dahlquist G. Can we slow the rising incidence of childhood-onset autoimmune diabetes? The overload hypothesis. Diabetologia 2006;49:20-4.

176.Ludvigsson J. Why diabetes incidence increases--a unifying theory. Ann N Y Acad Sci 2006;1079:37482.

177.Zhang Z, Li J, Yang L, et al. The cytotoxic role of intermittent high glucose on apoptosis and cell viability in pancreatic beta cells. J Diabetes Res 2014;2014:712781.

178. Helminen O, Aspholm S, Pokka T, et al. HbA1c Predicts Time to Diagnosis of Type 1 Diabetes in Children at Risk. Diabetes 2015;64:1719-27.

179. Wilcox AJ. On the importance--and the unimportance--of birthweight. Int J Epidemiol 2001;30:123341.

180. Oke SL, Hardy DB. The Role of Cellular Stress in Intrauterine Growth Restriction and Postnatal Dysmetabolism. Int J Mol Sci 2021;22.

181.Felicioni F, Santos TG, Paula T, Chiarini-Garcia H, de Almeida F. Intrauterine growth restriction: screening and diagnosis using animal models. Anim Reprod 2020;16:66-71.

182.Langley-Evans SC, McMullen S. Developmental origins of adult disease. Med Princ Pract 2010;19:8798.

183. Battaglia M, Ahmed S, Anderson MS, et al. Introducing the Endotype Concept to Address the Challenge of Disease Heterogeneity in Type 1 Diabetes. Diabetes Care 2020;43:5-12.

184. Larsson HE, Lynch K, Lernmark B, et al. Diabetes-associated HLA genotypes affect birthweight in the general population. Diabetologia 2005;48:1484-91.

185. Stene LC, Magnus P, Ronningen KS, Joner G. Diabetes-associated HLA-DQ genes and birth weight. Diabetes 2001;50:2879-82.

186. Aroviita P, Partanen J, Sistonen P, Teramo K, Kekomaki R. High birth weight is associated with human leukocyte antigen (HLA) DRB1*13 in full-term infants. Eur J Immunogenet 2004;31:21-6.

187.Jarvinen TM, Harjutsalo V, Kinnunen L, Miettinen ME, Tuomilehto-Wolf E, Tuomilehto J. A population-specific diabetogenic haplotype HLA-A2,Cw1,B56,DR4,DQ8 is associated with high birthweight in Finnish diabetic families. Genes Immun 2008;9:207-13. 
188. Hummel M, Marienfeld S, Huppmann M, et al. Fetal growth is increased by maternal type 1 diabetes and HLA DR4-related gene interactions. Diabetologia 2007;50:850-8.

189. Sterner Y, Torn C, Lee HS, et al. Country-specific birth weight and length in type 1 diabetes high-risk HLA genotypes in combination with prenatal characteristics. J Perinatol 2011;31:764-9.

190.Elding Larsson H, Vehik K, Haller MJ, et al. Growth and Risk for Islet Autoimmunity and Progression to Type 1 Diabetes in Early Childhood: The Environmental Determinants of Diabetes in the Young Study. Diabetes 2016;65:1988-95.

191.Ferrara-Cook C, Geyer SM, Evans-Molina C, et al. Excess BMI Accelerates Islet Autoimmunity in Older Children and Adolescents. Diabetes Care 2020;43:580-7.

192. Horikoshi M, Yaghootkar H, Mook-Kanamori DO, et al. New loci associated with birth weight identify genetic links between intrauterine growth and adult height and metabolism. Nat Genet 2013;45:76-82.

193. Clark MM, Chazara O, Sobel EM, et al. Human Birth Weight and Reproductive Immunology: Testing for Interactions between Maternal and Offspring KIR and HLA-C Genes. Hum Hered 2016;81:181-93.

194. Stene LC, Ronningen KS, Undlien DE, Joner G. Does the relative risk for type 1 diabetes conferred by HLA-DQ, INS, and PTPN22 polymorphisms vary with maternal age, birth weight, or cesarean section? Pediatr Diabetes 2011;12:91-4.

195.Locatelli M, Buzzetti R, Galgani A, et al. Length of gestation and gender are associated with HLA genotypes at risk for Type 1 diabetes (Italian DIABFIN 3). Diabet Med 2007;24:916-9.

196. National Board of Health and Welfare (2002) Report from EpC (Epidemiological centrum) Utvärdering av det svenska medicinska födelseregistret. [Evaluation of the Swedish Medical Birth Register] [article in Swedish] Available from: www.socialstyrelsen.se/lists/artikelkatalog/attachments/10961/2002-112-4_20021124.pdf Acessed 24 March 2016.

197.American Diabetes A. Diagnosis and classification of diabetes mellitus. Diabetes Care 2009;32 Suppl 1:S62-7.

198.Ludvigsson J, Carlsson A, Forsander G, et al. C-peptide in the classification of diabetes in children and adolescents. Pediatric diabetes 2012;13:45-50.

199. World Health Organisation, https://icd.who.int/browse10/2010/en\#/O20-O29. Accessed 211008

200.James PT, Leach R, Kalamara E, Shayeghi M. The worldwide obesity epidemic. Obes Res 2001;9 Suppl 4:228S-33S.

201.Kiviniemi M, Hermann R, Nurmi J, et al. A high-throughput population screening system for the estimation of genetic risk for type 1 diabetes: an application for the TEDDY (the Environmental Determinants of Diabetes in the Young) study. Diabetes Technol Ther 2007;9:460-72.

202. Clausen TD, Bergholt T, Eriksson F, Rasmussen S, Keiding N, Lokkegaard EC. Prelabor Cesarean Section and Risk of Childhood Type 1 Diabetes: A Nationwide Register-based Cohort Study. Epidemiology 2016;27:547-55.

203. Magnus MC, Olsen SF, Granstrom C, et al. Paternal and maternal obesity but not gestational weight gain is associated with type 1 diabetes. Int J Epidemiol 2018;47:417-26.

204. Hidayat K, Zou SY, Shi BM. The influence of maternal body mass index, maternal diabetes mellitus, and maternal smoking during pregnancy on the risk of childhood-onset type 1 diabetes mellitus in the offspring: Systematic review and meta-analysis of observational studies. Obes Rev 2019;20:1106-20.

205. Begum M, Pilkington RM, Chittleborough CR, Lynch JW, Penno M, Smithers LG. Effect of maternal smoking during pregnancy on childhood type 1 diabetes: a whole-of-population study. Diabetologia 2020;63:1162-73.

206. Mattsson K, Jonsson I, Malmqvist E, Larsson HE, Rylander L. Maternal smoking during pregnancy and offspring type 1 diabetes mellitus risk: accounting for HLA haplotype. Eur J Epidemiol 2015;30:231-8.

207. Magnus MC, Tapia G, Olsen SF, et al. Parental Smoking and Risk of Childhood-onset Type 1 Diabetes. Epidemiology 2018;29:848-56.

208. Qiu F, Liang CL, Liu H, et al. Impacts of cigarette smoking on immune responsiveness: Up and down or upside down? Oncotarget 2017;8:268-84.

209. Costenbader KH, Karlson EW. Cigarette smoking and autoimmune disease: what can we learn from epidemiology? Lupus 2006;15:737-45.

210. Wickstrom R. Effects of nicotine during pregnancy: human and experimental evidence. Curr Neuropharmacol 2007;5:213-22.

211. Yoshikawa H, Kurokawa M, Ozaki N, et al. Nicotine inhibits the production of proinflammatory mediators in human monocytes by suppression of I-kappaB phosphorylation and nuclear factor-kappaB transcriptional activity through nicotinic acetylcholine receptor alpha7. Clin Exp Immunol 2006;146:116-23.

212. Xu TY, Guo LL, Wang P, et al. Chronic exposure to nicotine enhances insulin sensitivity through alpha7 nicotinic acetylcholine receptor-STAT3 pathway. PLoS One 2012;7:e51217. 
213. Ahlsson F. Being born large for gestational age. Metabolic and epidemiological studies: Dissertation. Uppsala University, Faculty of medicine. ; 2008. ISBN 978-91-554-7246-7.

214. Versini M, Aljadeff G, Jeandel PY, Shoenfeld Y. Obesity: an additional piece in the mosaic of autoimmunity. Isr Med Assoc J 2014;16:619-21.

215.Boyden S. Autoimmunity and Inflammation. Nature 1964;201:200-1.

216. Granata M, Skarmoutsou E, Trovato C, Rossi GA, Mazzarino MC, D'Amico F. Obesity, Type 1 Diabetes, and Psoriasis: An Autoimmune Triple Flip. Pathobiology 2017;84:71-9.

217. Carlson MD, Morrison RS. Study design, precision, and validity in observational studies. J Palliat Med 2009; 12:77-82.

218. Merrill RM, Richardson JS. Validity of self-reported height, weight, and body mass index: findings from the National Health and Nutrition Examination Survey, 2001-2006. Prev Chronic Dis 2009;6:A121.

219. Seijo M, Minckas N, Cormick G, Comande D, Ciapponi A, BelizAn JM. Comparison of self-reported and directly measured weight and height among women of reproductive age: a systematic review and meta-analysis. Acta Obstet Gynecol Scand 2018;97:429-39.

220. Mattsson K, Kallen K, Rignell-Hydbom A, et al. Cotinine Validation of Self-Reported Smoking During Pregnancy in the Swedish Medical Birth Register. Nicotine Tob Res 2016;18:79-83.

221. Pourhoseingholi MA, Baghestani AR, Vahedi M. How to control confounding effects by statistical analysis. Gastroenterol Hepatol Bed Bench 2012;5:79-83. 
Paper I: Caesarean section per se does not increase the risk of offspring developing type 1 diabetes: a Swedish population-based study. Diabetologia 2015;58:2517-24

\begin{tabular}{|l|l|l|}
\hline Page/line & Original text & Correction \\
\hline Methods, MBR; 2518/70 & $\begin{array}{l}\text { In MBR, there are missing } \\
\text { data on BMI in early pregnancy } \\
(\mathrm{n}=12,021),\end{array}$ & $\begin{array}{l}\text { In MBR, there are missing } \\
\text { data on BMI in early pregnancy } \\
\text { (n=12,023), }\end{array}$ \\
\hline $\begin{array}{l}\text { Methods, Study population; } \\
\text { 2518/77 }\end{array}$ & $\begin{array}{l}\text { The children were born } \\
\text { between 1984 and 2012 }\end{array}$ & $\begin{array}{l}\text { The children were born } \\
\text { between 1982 and 2011 }\end{array}$ \\
\hline $\begin{array}{l}\text { Methods, Study population; } \\
\text { 2518/78 }\end{array}$ & $\begin{array}{l}\text { The age at diagnosis varied } \\
\text { from under 1 year of age up to } \\
17 \text { years of age }\end{array}$ & $\begin{array}{l}\text { The age at diagnosis varied } \\
\text { from under 1 year of age up to } \\
19 \text { years of age }\end{array}$ \\
\hline Results; 2520/Table 2 & $\begin{array}{l}\text { Vaginal delivery - } \\
\text { Mothers with diabetes } \\
\text { control: 75 (58.6) } \\
\text { children with T1D: 53 (41.4) }\end{array}$ & $\begin{array}{l}\text { Vaginal delivery - } \\
\text { Mothers with diabetes } \\
\text { control: 73 (57.9) } \\
\text { children with T1D: 53 (42.1) }\end{array}$ \\
\hline Results; 2520/Table 2 & $\begin{array}{l}\text { CS - Mothers with diabetes } \\
\text { control:253 (53.2) } \\
\text { children with T1D: 223 (46.8) }\end{array}$ & $\begin{array}{l}\text { CS - Mothers with diabetes } \\
\text { control:255 (53.3) } \\
\text { children with T1D: 223 (46.7) }\end{array}$ \\
\hline
\end{tabular}

Paper II: Maternal obesity as a risk factor for early childhood type 1 diabetes: a nationwide, prospective, population-based case-control study. Diabetologia 2018;61:130-137.

\begin{tabular}{|l|l|l|}
\hline Section; Page/line & Original text & Correction \\
\hline Table 1,133 & Term $(37-42$ weeks $)$ & Term $(37-41$ weeks $)$ \\
\hline Table 1,133 and Table 3,134 & Post-term $(>42$ weeks $)$ & Post-term $(\geq 42$ weeks $)$ \\
\hline Table 3, 134 & Overweight $(25.0-29.9)$ & Overweight $\left(25.0-29.9 \mathrm{~kg} / \mathrm{m}^{2}\right)$ \\
\hline Table 3,134 & Term $(37-42)$ & Term $(37-41$ weeks $)$ \\
\hline
\end{tabular}

Paper III: Size for gestational age affects the risk for type 1 diabetes in children and adolescents: a Swedish national case-control study. Diabetologia 2021;64:1113-20.

\begin{tabular}{|c|c|c|}
\hline Section; Page/line & Original text & Correction \\
\hline Statistical analyses; $1115 / 44$ & $\begin{array}{l}\text { The } \chi 2 \text { test was also utilised to } \\
\text { assess the association between } \\
\text { age at onset of type } 1 \text { diabetes } \\
\text { and gestational age and } \\
\text { birthweight. }\end{array}$ & $\begin{array}{l}\text { The } \chi 2 \text { test was also utilised to } \\
\text { assess the association between } \\
\text { age at onset of type } 1 \text { diabetes } \\
\text { and size for gestational age and } \\
\text { birthweight. }\end{array}$ \\
\hline $\begin{array}{l}\text { Method, MBR; } 1114 / 90 \\
\text { Table } 1 ; 1116 / 3 \text { line below table }\end{array}$ & duration of pregnancy $(n=657)$ & duration of pregnancy $(\mathrm{n}=57)$ \\
\hline Table 1;1116 and Table 3; 1118 & Term (37-42 weeks) & Term (37-41 weeks) \\
\hline Table $1 ; 1116$ & $\begin{array}{l}\text { Post term (>42 weeks) } 207 \\
(0.6)\end{array}$ & $\begin{array}{l}\text { Post term ( } \geq 42 \text { weeks) } 207 \\
(0.5)\end{array}$ \\
\hline Table 1;1116 & Overweight: $1611(23.1)$ & Overweight: $1611(23.2)$ \\
\hline Table 3; 1118 & Post term (>42 weeks) & Post term ( $\geq 42$ weeks $)$ \\
\hline Table $2 ; 1117$ & AGA: 33,035 (94.4) & AGA: $33,035(94.5)$ \\
\hline Table 2;1117 & Macrosomia: $7102(20.3)$ & Macrosomia: $7102(20.4)$ \\
\hline
\end{tabular}




\section{Papers}

The papers associated with this thesis have been removed for copyright reasons. For more details about these see:

http://urn.kb.se/resolve?urn=urn:nbn:se:liu:diva-180918 


\section{FACULTY OF MEDICINE AND HEALTH SCIENCES}

Linköping University Medical Dissertations No. 1789, 2021

Department of Biomedical and Clinical Sciences

Linköping University

SE-581 83 Linköping, Sweden

www.liu.se 